UNIVERSIDADE DE SÃO PAULO

FACULDADE DE ZOOTECNIA E ENGENHARIA DE ALIMENTOS

DEBORAH PEDROSO GALLES

\title{
IMPORTÂNCIA DA RELAÇÃO DOS ÁCIDOS GRAXOS OMEGA-6/OMEGA-3 NA ALIMENTAÇÃO
}


DEBORAH PEDROSO GALLES

\title{
IMPORTÂNCIA DA RELAÇÃO DOS ÁCIDOS GRAXOS OMEGA-6/OMEGA-3 NA ALIMENTAÇÃO
}

\author{
VERSÃO CORRIGIDA
}

Dissertação apresentada à Faculdade de Zootecnia e Engenharia de Alimentos da Universidade de São Paulo, como parte dos requisitos para a obtenção de título de Mestre em Ciência. Área de Concentração: Ciências da Engenharia de Alimentos.

Orientadora: Prof ${ }^{\mathrm{a}}$ Monica Roberta Mazalli

Pirassununga 
Dados Internacionais de Catalogação na Publicação

Serviço de Biblioteca e Informação da Faculdade de Zootecnia e Engenharia de Alimentos da Universidade de São Paulo

G166i

Galles, Deborah Pedroso

Importância da relação dos ácidos graxos ômega-6/

ômega-3 na alimentação / Deborah Pedroso Galles. --

Pirassununga, 2015.

$81 \mathrm{f}$.

Dissertação (Mestrado) -- Faculdade de Zootecnia e Engenharia de Alimentos - Universidade de São Paulo. Departamento de Engenharia de Alimentos.

Área de Concentração: Ciências da Engenharia de

Alimentos.

Orientadora: Profa. Dra. Monica Roberta Mazalli.

1. Ácidos graxos poliinsaturados 2. Omega-6

3. Omega-3 4. Aterosclerose 5. Coelhos. I. Título. 


\section{DEDICATÓRIA}

Aos meus amados pais Fernando e Silvia por todo o amor, carinho e apoio; Ao meu irmão Daniel e minha avó Odette por cuidarem de mim;

Ao meu amor Roberto pelas palavras e apoio; Com todo meu amor dedico este trabalho a vocês. 


\section{AGRADECIMENTOS}

A Deus pelo dom da vida e por todas as oportunidades e proteção.

Aos meus pais Fernando e Silvia por todas as batalhas, dedicação em minha criação, apoio em todas as fases da minha vida e amor dedicado. Por serem meus exemplos. Amo vocês para sempre.

Ao meu namorado Roberto, pelo apoio e suporte nestes anos longe. Pelas sábias palavras e por ser um exemplo de pessoa e profissional. Você é o amor da minha vida!

Ao meu irmão Daniel e minha avó Odette por sempre estarem presentes nos principais momentos da minha vida.

A minha avó Wilma (in memorian) por ter proporcionado uma infância tão feliz e com tantas lembranças em sua casa.

Aos meus bichinhos, Toy (in memoriam), por ser a principal razão na escolha da minha profissão, saudades imensas e eternas. Chico, pelas despedidas tristes e recepções calorosas nas minhas viagens semanais para Pirassununga. Lola e Milk, presentes que Pira me deu. Amo vocês!

A minha amiga Mariane pela amizade e carinho por todos estes anos, companheira de tantas aventuras, de momentos difíceis e muitas risadas, mas principalmente por me transformar em uma Silva! Amo muito você!

A toda a família da Mari, Tia Sandra (Sandrinha), Tio Roberto (Betão), Vó Mércia, Aline, Du, Rômulo, Bia, Yuri, Luna e Naila (in memorian), por sempre me receberem de braços abertos "nas casas" de vocês, como membro da família e cuidarem de mim. Amo vocês!

A Universidade de São Paulo e a Faculdade de Zootecnia e Engenharia de Alimentos pela oportunidade de realização do Mestrado.

A minha orientadora Mônica Roberta Mazalli por me aceitar como sua primeira aluna de mestrado, pela dedicação intensa e pelas palavras de amizade e carinho. Você é uma querida! Muito obrigada!

Ao José Roberto Medina, marido da professora Mônica, pela ajuda com seu vasto conhecimento em nutrição animal e pelos finais de semana perdidos misturando as rações. Meus mais sinceros agradecimentos.

A Professora Angélica Simone Cravo Pereira, por me abrir as portas da USP e me colocar em ótimas mãos. Obrigada também pelo meu maior presente: a Lola! 
Ao Professor Flávio Vieira Meirelles pela colaboração no projeto com seu conhecimento e por disponibilizar seus equipamentos e laboratório.

A família de Pirassununga: Lucinéia, Simi e Professor Márcio, muito obrigada pelos momentos descontraídos e alegres com vocês.

A minha amiga Nara pela companhia e risadas de muitas noites, pelas comidinhas maravilhosas e especiais sempre que tinha vontade e por cuidar de mim durante viroses e crises renais! Muitas saudades, te amo!

Ao Rodrigo Barreto por toda a ajuda e por transferir seus conhecimentos com tanto bom humor. Por atender as minhas dúvidas a todos os momentos e lugares. Você se tornou um amigo querido e eu te desejo tudo de melhor e ainda mais sucesso!

A Rafaella Maniriques, aluna de iniciação científica, pela contribuição neste trabalho. Obrigada Rafa!

As amigas que fiz durante o mestrado, Luciana, Laura e Juliana. Muito obrigada!

As minha amigas de tantos anos Maria Cecília, Julia, Natália e Bruna por estarem sempre ao meu lado. Amo vocês!

Aos meus sogros Roberto e Glória pela torcida e comemorar minhas conquistas. Todo meu carinho para vocês!

A FAPESP (Fundação de Amparo a Pesquisa do Estado de São Paulo) (Processo FAPESP $\mathrm{N}^{\circ}$ 2009/ 14656-0) pelo financiamento da minha pesquisa.

A Banca Examinadora, por dedicar seu tempo a avaliação do meu trabalho.

$\mathrm{E}$ a todos aqueles não citados que contribuíram direta ou indiretamente para a realização deste trabalho. Muito Obrigada! 


\section{EPÍGRAFE}

"O período de maior ganho em conhecimento e experiência é o período mais dificil da vida de alguém."

Dalai Lama

"Aquele que não compartilha seu conhecimento, deixa morrer consigo os frutos de sua sabedoria."

Hélcio Macedo 


\section{RESUMO}

\section{Galles, D.P. Importância da relação dos ácidos graxos Omega-6/Omega-3 na alimentação.}

2015. 81 p.. Dissertação (Mestrado) - Faculdade de Zootecnia e Engenharia de Alimentos, Universidade de São Paulo, Pirassununga, 2015.

O experimento foi realizado no Biotério Experimental da USP em Pirassununga - SP. Na primeira fase foram utilizados 42 coelhos machos em crescimento da raça Nova Zelândia mantidos individualmente durante todo o experimento. $\mathrm{O}$ ensaio biológico totalizou 150 dias. $\mathrm{Na}$ Fase 1 os animais receberam dietas com indução de hipercolesterolemia (0,5\% de colesterol), com desequilíbrio na proporção de Omega-6/Omega-3 (n-6:n-3) de 15:1 e vice versa e balanço na proporção de n-6:n-3 de 4:1 (controle), totalizando 6 ensaios, os quais foram divididos aleatoriamente em 7 grupos de 6 coelhos cada. Óleos de girassol e de peixe foram utilizados como fontes de ácidos graxos poli-insaturados n-6 e n-3, respectivamente. Na Fase 2, os animais remanescentes continuaram recebendo as mesmas dietas, exceto no grupo $\mathrm{B}$ (hipercolesterolemia) que passou a receber o tratamento controle para verificar o efeito. No final da Fase 1, três animais de cada grupo foram eutanasiados com retirada da artéria aorta para determinação de placas lipídicas, histopatológica, colesterol total e imunohistoquímica para verificação da expressão da enzima LDL-receptor e determinação histopatológica do tecido hepático. Em soro foram realizadas determinações de perfil de ácidos graxos, colesterol total, LDL e HDL-colesterol e triacilgliceróis. Células endoteliais aórticas de coelhos foram isoladas para a realização do teste dose resposta com óleo de peixe para identificar a melhor relação do consumo destes ácidos graxos comparando com o experimento in vivo. O objetivo deste trabalho foi monitorar os efeitos do fornecimento de cada dieta sobre o teor de colesterol total, LDLcolesterol, HDL-colesterol e triacilgliceróis em sangue de coelhos. No geral, o perfil de ácidos graxos no soro correspondeu diretamente com a dieta consumida. Os principais efeitos dos ácidos graxos poli-insaturados Omega 3 foi a redução dos lipídios séricos quando os coelhos remanescentes da dieta hipercolesterolêmica (0,5\% de colesterol e n-6:n-3 de 2:1) passaram a receber o equilíbrio da relação de ácidos graxos 4:1 de n-6:n-3. O teor de colesterol total no soro, artérias e o crescimento dos ateromas foram influenciados pelo elevado consumo de ácidos graxos n-6 e n-3 associados à adição de colesterol nas dietas. Por outro lado verificamos que o 
excesso de Omega 3 associado ou não ao colesterol contribuiu para o agravamento das placas ateroscleróticas inclusive deposição de cálcio nas mesmas e paredes endoteliais. Provavelmente, o excesso de n-3 tenha ocasionado efeito contrário às suas funções anti-inflamatória, antiagregatória e anti-trombótica. Dietas hipercolesterolêmicas provocaram esteatose hepática e o elevado consumo de Omega-6 em detrimento do baixo consumo de Omega -3 induziram hepatite crônica. Já o consumo elevado de Omega-3, sem colesterol, regrediu a esteatose hepática nos animais. O consumo equilibrado de n-6:n-3 reduziu a expressão da enzima LDL-receptor no grupo que anteriormente recebeu dieta hipercolesterolêmica. Ressaltando-se a importância do consumo equilibrado destes ácidos graxos já que esta enzima é controlada pelo colesterol livre circulante. No teste dose-resposta em células endoteliais da aorta de coelhos foi evidenciado que a melhor proporção de n-6:n-3 seria de 9 vezes mais do que a concentração de Omega 3 recomendada de 5:1.

Palavras-Chave: Ácidos Graxos Poli-insaturados, Omega-6, Omega-3, Aterosclerose, Coelhos. 


\begin{abstract}
Galles, D.P. Importance of the relation of the fatty acids Omega-6/Omega-3 in the feeding.. 2015. 81 p.. M. Sc. Dissertation - Faculdade de Zootecnia e Engenharia de Alimentos, Universidade de São Paulo, Pirassununga, 2015.
\end{abstract}

The experiment was conducted at the Experimental Biotery by USP in Pirassununga - SP. In the first phase were used 42 male rabbits growing New Zealand breed individually maintained throughout the experiment. The biological assay amounted to 150 days. In phase 1, the animals received diets induced hypercholesterolemia ( $0.5 \%$ cholesterol) with imbalance in the ratio of Omega-6 / Omega-3 (n-6/n-3) 15: 1 and vice versa, and balance the ratio of n-6/n-3 of 4: 1 (control), totaling six tests, which were randomly divided into 7 groups of six rabbits each. Sunflower and fish oils were used as sources of fatty acids polyunsaturated n-6 and n-3, respectively. In Phase 2, the remaining animals continued to receive the same diets except in group B (hypercholesterolemia) who went on to receive the control treatment to check the effect. At the end of Phase 1, three animals from each group were sacrificed with the aorta artery removed for determination of lipid plaques, histopathology, immunohistochemistry and total cholesterol to verify the expression of LDL-receptor enzyme and determination of histopathological liver tissue. In serum profile were made determinations of fatty acids, total cholesterol, LDL and HDL cholesterol and triglycerides. Aortic endothelial cells of rabbits were isolated to perform the dose response test with fish oil to identify the best value for the consumption of these fatty acids compared to the in vivo experiment. The objective of this work was to monitor the effects of provision for each diet on total cholesterol, LDL-cholesterol, HDLcholesterol and triglycerides in the blood of rabbits. In general, the profile of fatty acids in serum corresponded directly with the diet consumed. The main effects of polyunsaturated Omega 3 fatty acids was the reduction of serum lipids when the remaining rabbits with hypercholesterolemic diet $(0.5 \%$ cholesterol and n- $6: n-32: 1)$ have received the balance of the relationship fatty acid 4 : $1 \mathrm{n}-6: \mathrm{n}-3$. The total cholesterol content in serum, the growth of arteries and atheroma were influenced by a high intake of n-6 fatty acids and n-3 associated with the addition of cholesterol in diets. On the other hand we verified that the excess of Omega 3 with or without cholesterol contributed to the aggravation of the atherosclerotic plaques including deposition of calcium in them and endothelial walls. Probably the excess of n-3 has caused the opposite effect to their 
anti-inflammatory, anti-thrombotic and anti-aggregatory functions. Hypercholesterolemic diets caused hepatic steatosis and high intake of Omega- 6 to the detriment of low consumption of Omega -3 induced chronic hepatitis. High consumption of Omega-3, no cholesterol, decreased hepatic steatosis in animals. Highlighting the importance of the balanced intake of this fatty acids, since this enzyme is controlled by circulating free cholesterol. In dose-response test in endothelial cells of the rabbits aorta was evident that the best ratio of $n-6: n-3$, nine times more than the recommended concentration of Omega 3 to $5: 1$.

Keywords: Polyunsaturated Fatty Acids, Omega-6, Omega-3, Atherosclerosis, Rabbits. 


\section{LISTA DE ILUSTRAÇÕES}

Figura 1. Esquema ilustrativo da síntese de ácidos graxos insaturados

Figura 2. Partículas de LDL (Lipoproteína de Baixa Densidade) e seus componentes; Estrutura da enzima LDL-Receptor .

Figura 3. Mecanismos de autoxidação do colesterol.

Figura 4. Determinação planimétrica das placas de ateroma e artérias de coelhos - Tratamento A.

Figura 5. Determinação planimétrica das placas de ateroma e artérias de coelhos - Tratamento B

Figura 6. Determinação planimétrica das placas de ateroma e artérias de coelhos - Tratamento C

Figura 7. Determinação planimétrica das placas de ateroma e artérias de coelhos - Tratamento D

Figura 8. Determinação planimétrica das placas de ateroma e artérias de coelhos - Tratamento E

Figura 9. Determinação planimétrica das placas de ateroma e artérias de coelhos - Tratamento F.

Figura 10. Determinação planimétrica das placas de ateroma e artérias de coelhos - Tratamento G.

Figura 11. Gráfico da análise da expressão da enzima LDL-receptor em artérias de coelhos do período total de experimento. Tratamentos: A (n-6:n-3 de 4:1); B (0,5\% de colesterol e n-6:n-3 de 2:1; C (0,5\% de colesterol e n-6:n-3 de 15:1; D (n-6:n-3 de 15:1); E (0,5\% de colest colesterol e n-6:n-3 de 1:15; F(n-6:n-3 de 1:15) e G (ração comercial de coelho).

Figura 12. Análise imunohistoquímica em artérias de coelhos do segundo período, anticorpo

LDL-r - Tratamento A 57

Figura 13. Análise imunohistoquímica em artérias de coelhos do segundo período, anticorpo LDL-r - Tratamento B.

Figura 14. Análise imunohistoquímica em artérias de coelhos do segundo período, anticorpo LDL-r - Tratamento C 58 
Figura 15. Análise imunohistoquímica em artérias de coelhos do segundo período, anticorpo LDL-r - Tratamento D.

Figura 16. Análise imunohistoquímica em artérias de coelhos do segundo período, anticorpo LDL-r - Tratamento E.

Figura 17. Análise imunohistoquímica em artérias de coelhos do segundo período, anticorpo LDL-r - Tratamento F.

Figura 18. Análise imunohistoquímica em artérias de coelhos do segundo período, anticorpo LDL-r - Tratamento G. 59

Figura 19. Identificação celular por citometria de fluxo através de parâmetros físicos (tamanho $\mathrm{x}$ complexidade) e seleção da população celular. 64

Figura 20. Histogramas das porcentagens de fluorescência e quantidade relativa de células para o controle negativo. 64

Figura 21. Histogramas das porcentagens de fluorescência e quantidade relativa de células para o controle positivo. 64

Figura 22. Histogramas das porcentagens de fluorescência e quantidade relativa de células para a placa 5 65

Figura 23. Histogramas das porcentagens de fluorescência e quantidade relativa de células para a placa 6 65

Figura 24. Histogramas das porcentagens de fluorescência e quantidade relativa de células para a placa 7 65

Figura 25. Histogramas das porcentagens de fluorescência e quantidade relativa de células para a placa 8 


\section{LISTA DE TABELAS}

Tabela 1. Composição e níveis nutricionais calculados das dietas experimentais. ..................... 30

Tabela 2. Maior composição de ácidos graxos em soro $(\mathrm{g} / 100 \mathrm{~g})$......................................... 37

Tabela 3. Dose de Omega-3 e Omega-6 em células endoteliais de coelhos.............................. 38

Tabela 4. Resultados do Perfil de Ácidos Graxos em soro de coelhos no período de 75 dias de

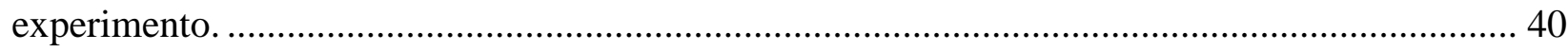

Tabela 5. Teor médio de colesterol total, LDL-colesterol, HDL-colesterol e triacilgliceróis (mg/dL) em soro de coelhos nos períodos de 75 dias e 150 dias de experimento...................... 44

Tabela 6. Teor de colesterol total e determinação planimétrica em artérias de coelhos nos

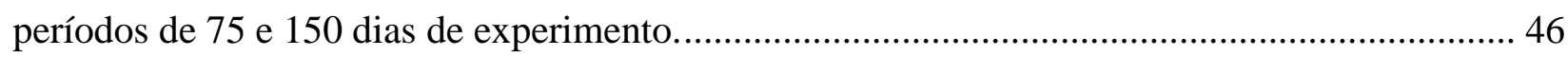

Tabela 7. Determinações histopatológicas em artérias e tecidos em coelhos no período de 75

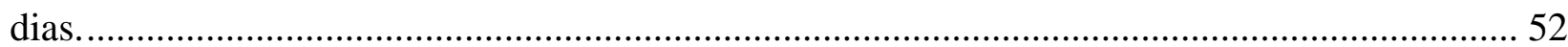

Tabela 8. Determinações histopatológicas em artérias e tecidos em coelhos no período de 150 dias. 53

Tabela 9. Quantificação de DNA e RNA em células endoteliais de coelhos que receberam óleo de peixe.......

Tabela 10. Citometria de fluxo das células endoteliais de aorta de coelhos que receberam óleo de peixe. 


\section{SUMÁRIO}

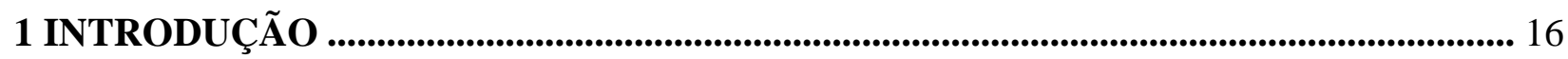

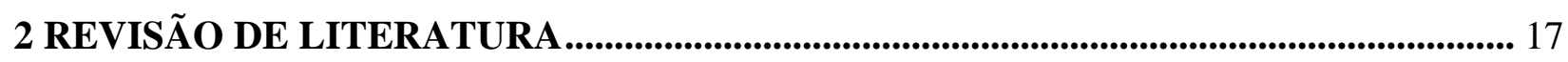

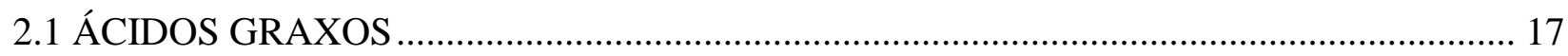

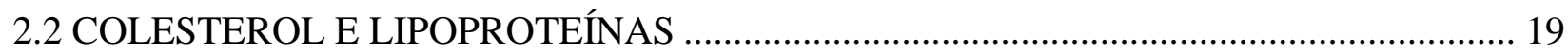

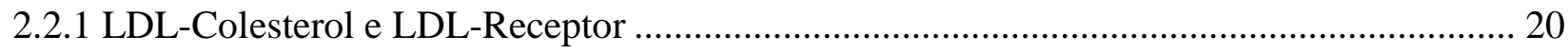

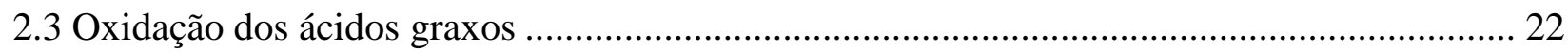

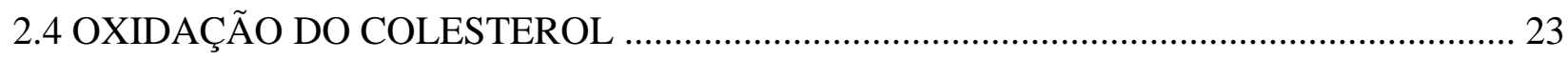

2.5 Efeitos Biológicos da Oxidação do Colesterol .................................................................... 25

2.6 Efeitos das Fontes de Ácidos Graxos Poli-insaturados Sobre a Saúde Humana...................... 26

3 OBJETIVOS ........................................................................................................................................ 28

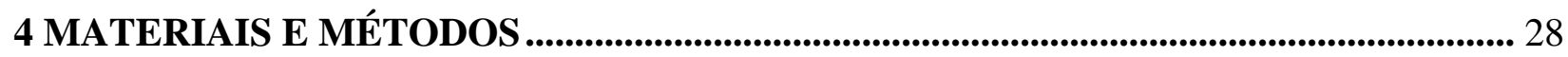

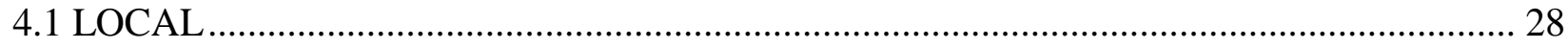

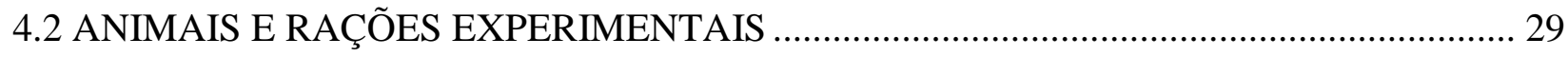

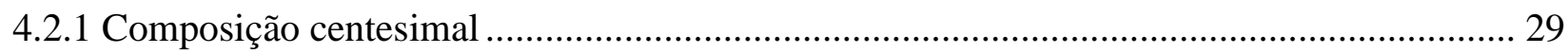

4.3 ABATE DOS COELHOS, COLETA DE SANGUE E OBTENÇÃO DO SORO. .................. 31

4.3.1 Abate dos Coelhos .......................................................................................................... 31

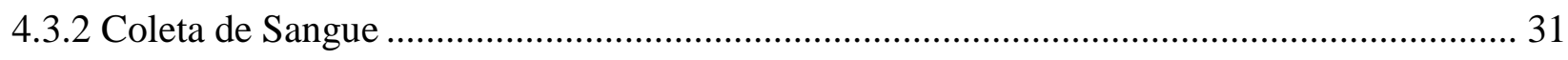

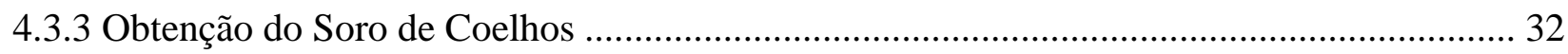

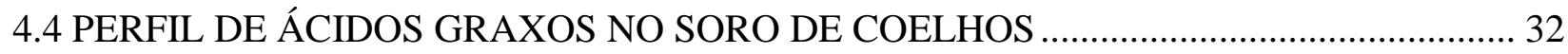

4.5 DETERMINAÇÕES DAS LIPOPROTEÍNAS LDL E HDL-COLESTEROL E

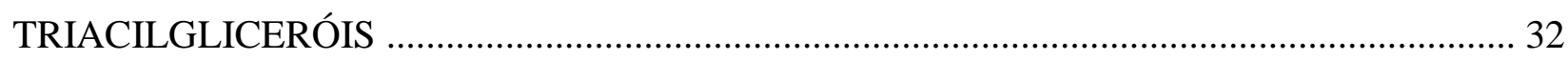

4.6 OBTENÇÃO DOS TECIDOS DA ARTÉRIA AORTA E FÍGADO ………………….......... 32

4.6.1 Determinação do Teor de Colesterol Total da Artéria …………………………................ 33

4.6.2 Determinação Planimétrica de Placas Lipídicas na Artéria Aorta ........................................ 33

4.6.3 Análise Histopatológica de Artéria Aorta e Fígado............................................................. 33

4.6.4 Análise da Expressão Gênica da LDL-Receptor por Imunohistoquímica em Artérias no

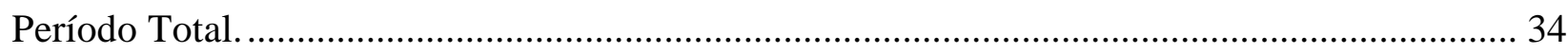


4.7 DETERMINAÇÃO IN VITRO DA MELHOR RELAÇÃO DE ÁCIDOS GRAXOS N-

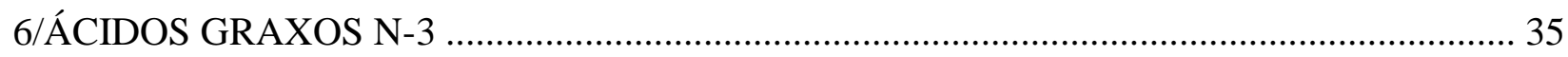

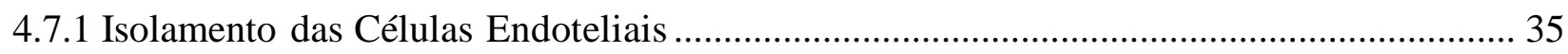

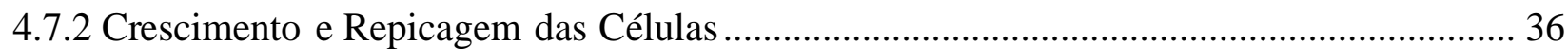

4.7.3 Determinação de Ácidos Graxos no Soro de Coelhos e Soro Fetal Bovino de Referência . 36

4.7.4 Teste Dose-Resposta Induzido por Ácido Graxo Poli-insaturado Omega-3 em Células

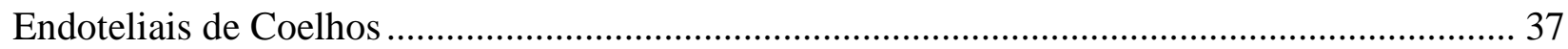

4.7.4.1 Extração e Quantificação de RNA, DNA ………………………………….................... 38

4.7.4.2 Potencial de Membrana Mitocondrial ........................................................................... 38

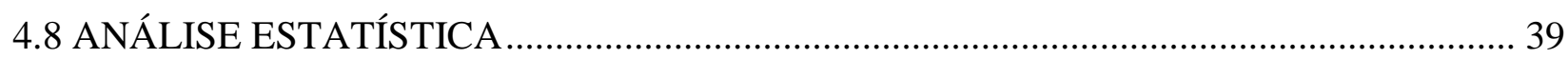

4.8.1 Estatística da Análise de Imunohistoquímica......................................................................... 39

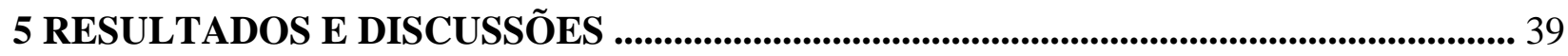

5.1 PERFIL DE ÁCIDOS GRAXOS NO SORO DE COELHOS …............................................. 39

5.2 TEOR DE COLESTEROL TOTAL, LDL-COLESTEROL, HDL-COLESTEROL E

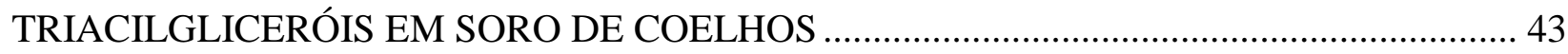

5.3 TEOR DE COLESTEROL TOTAL E DETERMINAÇÕES PLANIMÉTRICAS DE PLACAS LIPÍDICAS NA ARTÉRIA AORTA EM COELHOS ………………………............... 46

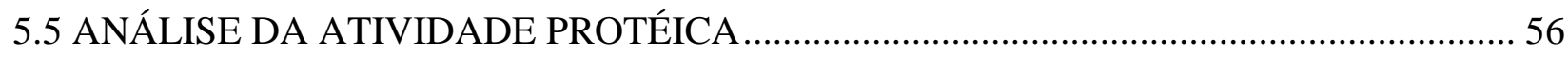

5.5.1 Análise Imunohistoquímica da Enzima LDL-Receptor em Artérias de Coelhos no Período

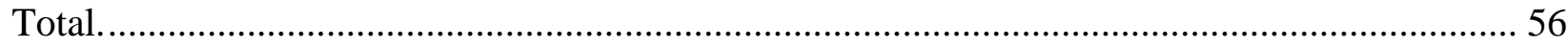

5.6 DETERMINAÇÃO IN VITRO DA MELHOR RELAÇÃO DE ÁCIDOS GRAXOS N-

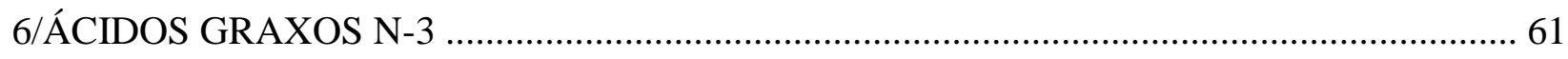

5.6.1 Quantificação de ácidos graxos n-3 e n-6 em Soro de Coelhos e Soro Fetal Bovino de Referência

5.6.2 Teste dose-resposta induzido por Ácido Graxo Poli-insaturados Omega-3 em Células Endoteliais de Coelhos 61

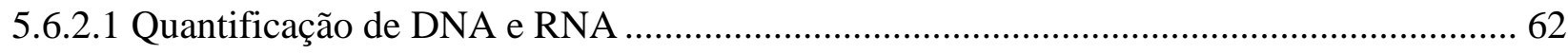

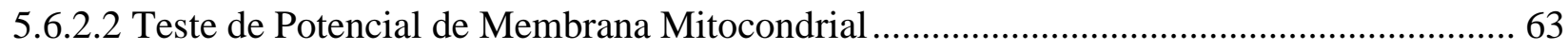

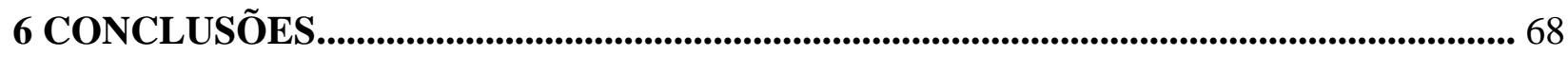

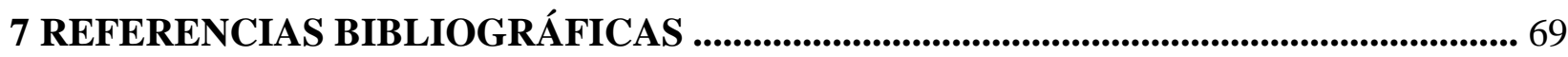




\section{INTRODUÇÃO}

Atualmente a interação ambiente e dieta nos seres humanos difere da qual sua constituição genética foi selecionada. Essa mudança na dieta é caracterizada pelo aumento da gordura total, especialmente as gorduras saturadas e os ácidos graxos Omega 6. Por outro lado, o consumo de ácidos graxos Omega 3 diminuiu em comparação ao de Omega 6 durante nossa evolução (BLASBALG et. al., 2011; SIMOPOULOS 2008a; SIMOPOULOS, 2008b). Na vida primitiva, a relação entre os ácidos graxos poli-insaturados (PUFA) Omega 6/Omega3 (n-6:n-3) era de 2:1. Com o abandono dos hábitos primitivos e a consequente evolução da espécie humana, os hábitos alimentares foram intensamente modificados, passando essa relação para 15-20:1 (EATON et al., 1998a; 1998b).

O equilíbrio da relação de ácidos graxos n-6 / ácidos graxos n-3 ainda não está claramente estabelecido para indivíduos saudáveis. A maioria dos estudos são realizados em indivíduos que apresentaram hipercolesterolemia e outras enfermidades crônicas. Além disso, as recomendações para um consumo ideal de ácidos graxos n-6 / ácidos graxos n-3 não apresentam evidências científicas suficientes dos órgãos oficiais, variando na proporção de 4 a 10:1, respectivamente.

É evidente que o decréscimo na ingestão de n-3 está relacionado com a baixa ingestão de peixes e as novas tecnologias de criação animal que adotaram uma alimentação rica em cereais e, portanto, com altas taxas de n-6 e baixas taxas de n-3, levando consequentemente a um empobrecimento destes últimos em seus produtos.

Com a sociedade atual caracterizada pelo aumento do consumo de energia além da redução do seu gasto, resultante do sedentarismo e o fácil acesso a alimentos industrializados ricos em gorduras saturadas, ácidos graxos n-6, ácidos graxos trans e pobres em ácidos graxos n3, aumento na ingestão de grãos e diminuição no consumo de frutas e vegetais causou um conflito em nosso genoma. Assim, as doenças cardiovasculares se tornaram uma das principais causas de mortalidade no mundo, resultando em uma preocupação na associação dieta e saúde, principalmente, na relação entre nutrição lipídica e essas enfermidades (REAVEN, 2005; SIMOPOULOS, 2008a).

De fato, o elevado consumo de ácidos graxos n-6, em detrimento de ácidos graxos n-3 promovem a patogênese de diversas doenças degenerativas, tais como: aterosclerose, hipertensão, 
obesidade, diabetes, doenças autoimunes, câncer de mama, cólon e próstata (HUGHESFULFORD et al., 2005, HEDELIN et al., 2007, SHANNON et al., 2007, HAVEL, 2010, MAYNERIS-PERXACHS et al., 2010).

A proporção dos diferentes tipos de ácidos graxos poli-insaturados na membrana da célula influencia as propriedades das membranas (VAJRESWARI et al., 2002) e a liberação de mediadores inflamatórios (JAMES; GIBSON; CLELAND, 2000). Além disso, alguns estudos revelaram que o excesso de ácidos graxos da série n-6 tem efeitos deletérios, como provocar a diminuição de lipoproteína de alta densidade (HDL), aumentando a suscetibilidade à oxidação da lipoproteína de baixa densidade (LDL) que é a principal responsável pelo transporte de colesterol para os tecidos periféricos e pela severidade dos danos causados às paredes coronárias (GIRAO et al., 2008; LICHTENSTEIN et al., 1994; LOUHERANTA et al., 1996).

Considerada uma "doença ocidental", a aterosclerose é a enfermidade que mais causa mortes. A patologia consiste em um processo crônico, progressivo e sistêmico que se caracteriza por uma resposta inflamatória e fibroproliferativa da parede arterial, causada por agressões à superfície arterial (ROSS, 2005; LUZ; UINT, 2003; CALZOLARI; FUMAGALLI; MARCHIONNI, 2009).

Coelhos têm sido amplamente utilizados como um modelo animal para o estudo da aterosclerose (YANNI, 2004), sendo induzida por meio do fornecimento de colesterol na ração (KOLODGIE et al., 2003 e CAYLI; SATI; SEVAL-CELIK, 2010). O método se mostra muito efetivo na formação das lesões ateroscleróticas nas aortas torácica e abdominal como também demonstra ser fidedigno no estudo da aterosclerose (McMAHAN; GIDDING; McGILL, 2008).

\section{REVISÃO DE LITERATURA}

\section{1 ÁCIDOS GRAXOS}

A designação de Omega (n) tem relação com a posição da primeira dupla ligação, contando a partir do carbono terminal $(\mathrm{CH} 3)$ do grupo metila, tendo maior significado do que o grupo carboxila, o que relaciona à importância nutricional destes ácidos graxos. $\mathrm{O}$ ácido linoleico e o ácido $\alpha$-linolênico são ácidos graxos essenciais por possuírem duplas ligações no terceiro e 
sexto átomos de carbono e não serem sintetizados pela espécie mamífera, por falta de enzimas que introduzam essas duplas ligações.

O processo de alongamento dos ácidos graxos ocorre no retículo endoplasmático e consiste em uma sequência de reações cíclicas que agregam duas moléculas de carbono a um substrato ocorrendo em quatro etapas: condensação, redução, desidratação e redução. Os carbonos formam-se por meio da condensação do acetil-CoA com o malonil-CoA, atuando como doador e o NADPH como agente redutor, obtendo o 3-cetoacil-CoA, sendo que a redução deste, origina o 3-hidróxiacil-CoA, que após sofrer desidratação, produz trans-2-enoil-CoA, que finalmente sofre redução para formar o Acetil-CoA alongado (CINTI et al., 1992; JAKOBSSON et al., 2006; GUILLOU et al., 2010). O processo de dessaturação caracteriza-se pela adição de duplas ligações em posições específicas das cadeias de ácidos graxos. Essa reação é catalisada por enzimas chamadas dessaturases ou acil CoA dessaturases. Essas enzimas introduzem a dupla ligação nas cadeias de acila dos ácidos graxos de cadeia longa, influenciando, assim, as principais propriedades biológicas do ácido graxo e de lipídios mais complexos que contêm esta cadeia acil em sua composição (GUILLOU et al., 2010). Em plantas estão presentes a $\Delta$-12 dessaturase e $\Delta$ 15 dessaturase, nas células animais estão presentes as $\Delta-5, \Delta-6$ e $\Delta-9$ dessaturases (TEITELBAUM e WALKER, 2001). O número $\Delta$ indica a posição na qual a dupla ligação será introduzida (GUILLOU et al., 2010). Além disso, os processos de dessaturação e alongamentos que originam os ácidos graxos poli-insaturados (PUFA) são os mesmos (Figura 1), o que gera competição no metabolismo das duas séries n-6 e n-3, sendo assim, o excesso de n-6 presente na dieta limita a formação de PUFA n-3.

Por serem deficientes de forma endógena, torna-se importante uma dieta contendo linoleico n-6 e da série n-3 como: $\alpha$ linolênico (LNA), eicosapentaenóico (EPA) e docosahexaenóico (DHA). (SIMOPOULOS, 2008a). Gorduras, óleos, carnes bovinas e de aves, cereais, vegetais, oleaginosas e sementes são importantes fontes de ácidos graxos poli-insaturados Omega-6. O óleo de girassol contém aproximadamente $11 \%$ de ácido graxo saturado, $69 \%$ de PUFA e $20 \%$ de ácido graxo monoinsaturado. Há variedades de girassol contendo $18 \%$ de ácidos Graxos da família $n$-9 e outra com $21 \%$ de LA da família $n-6$ (NETTLETON, 1995).

Já peixes e frutos do mar, são as principais fontes de ácidos graxos poli-insaturados Omega-3 (MEYER et al., 2003). 
n-6

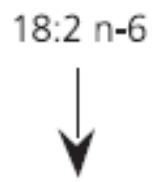

$18: 3 n-6$

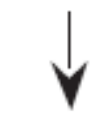

$20: 3 n-6$

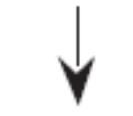

$20: 4 n-6$

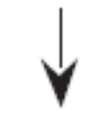

$22: 4 n-6$
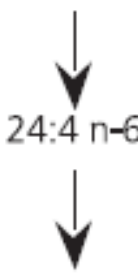

$24: 5 n-6$

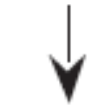

$22: 5 n-6$ $n-3$

$18: 3 n-3$

$\Delta 6$-dessaturase

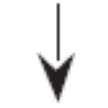

$18: 4 n-3$

alongase

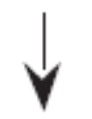

20:4 n-3

$\Delta 5$-dessaturase

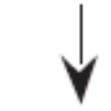

20:5 n-3

alongase

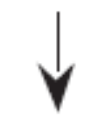

$22: 5 n-3$

alongase

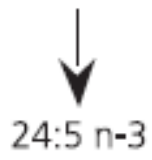

$\Delta 6$-dessaturase

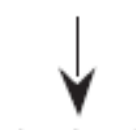

$24: 6 n-3$

$\beta$-oxidação

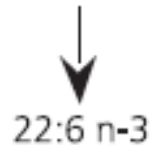

Figura 1. Esquema ilustrativo da síntese de ácidos graxos insaturados (CHAMPE e HARVEY, 1997).

\subsection{COLESTEROL E LIPOPROTEÍNAS}

O colesterol é um lipídio essencial que atua como o principal constituinte estrutural das membranas celulares e lipoproteínas plasmáticas e também é um precursor de hormonios esteróides e ácidos biliares.

O colesterol contém uma dupla ligação no carbono 5, e deste modo, os pontos susceptíveis da estrutura à oxidação são os carbonos nas posições 4 e 7 . Entretanto, devido à 
possível influência do grupo hidroxila no carbono 3, o oxigênio raramente ataca nas posições dos carbonos 4 e 5, sendo predominante no carbono 7 (WASOWICZ, 2003).

As lipoproteínas são estruturas organizadas responsáveis pelo transporte de lipídios, após sua absorção, no plasma. As lipoproteínas plasmáticas desempenham um papel principal na remoção e deposição de lipídios que se acumulam em lesões ateroscleróticas (CASTELLI et al., 1992) e são geralmente associadas a papéis fisiológicos específicos considerando as frações de densidade (HAVEL, 2010). O excesso de tracilgliceróis e colesterol necessários ao fígado são exportados para o sangue em forma de VLDL, tanto estes como os quilomícrons sofrem hidrólise pela ação das lipases hepáticas originando as IDL que terão duas vias: sendo metade captada pelo

fígado e a outra parte convertida em LDL que irá transportar colesterol para os tecidos periféricos e regular sua síntese nestes locais (BERG; TYMOCZKO; STRYER, 2002).

Segundo Ganong (1995), as lipoproteínas são classificadas com a densidade crescente, essa classificação é baseada no diferencial de flutuação: quilomícrons que transportam os triacilgliceróis da dieta pela mucosa intestinal até o tecido muscular e adiposo e os quilomícrons remanescentes (ésteres de colesterol da dieta) que são captados pelo fígado.

A VLDL (lipoproteína de muita baixa densidade) é sintetizada pelo fígado e transporta colesterol e triacilgliceróis para o tecido extra-hepático e são hidrolisados pela lipoproteína lipase até ácidos graxos livres e colesterol. A IDL (lipoproteínas de densidade intermediária) produto da ação da lipoproteína lipase na VLDL, sendo precursora da LDL (lipoproteínas de baixa densidade): fonte primária do colesterol (BERG, 2002), transportam lipídios para os tecidos periféricos, sua remoção da circulação é feita por receptores LDL. As HDL (lipoproteínas de alta densidade): recolhem lipídios do tecido periférico, transportando-os para o fígado para reutilização ou excreção (WALZEM, 1996).

\subsubsection{LDL-Colesterol e LDL-Receptor}

A lipoproteína LDL (lipoproteínas de baixa densidade) é a principal portadora de lípidos no plasma humano, consiste principalmente de ésteres de colesterol (29\%), fosfolípidos (28\%), proteínas (21\%), colesterol livre (11\%) e triacilgliceróis (9\%) (SCANU; SPECTOR, 1986). 
Cada partícula de LDL (Figura 2) contém uma molécula de apolipoproteína B-100 (apoB). A ApoB é sintetizada no fígado e no intestino delgado para formar lipoproteína de muito baixa densidade (VLDL) e quilomícrons, respectivamente (INNERARITY, 1996).
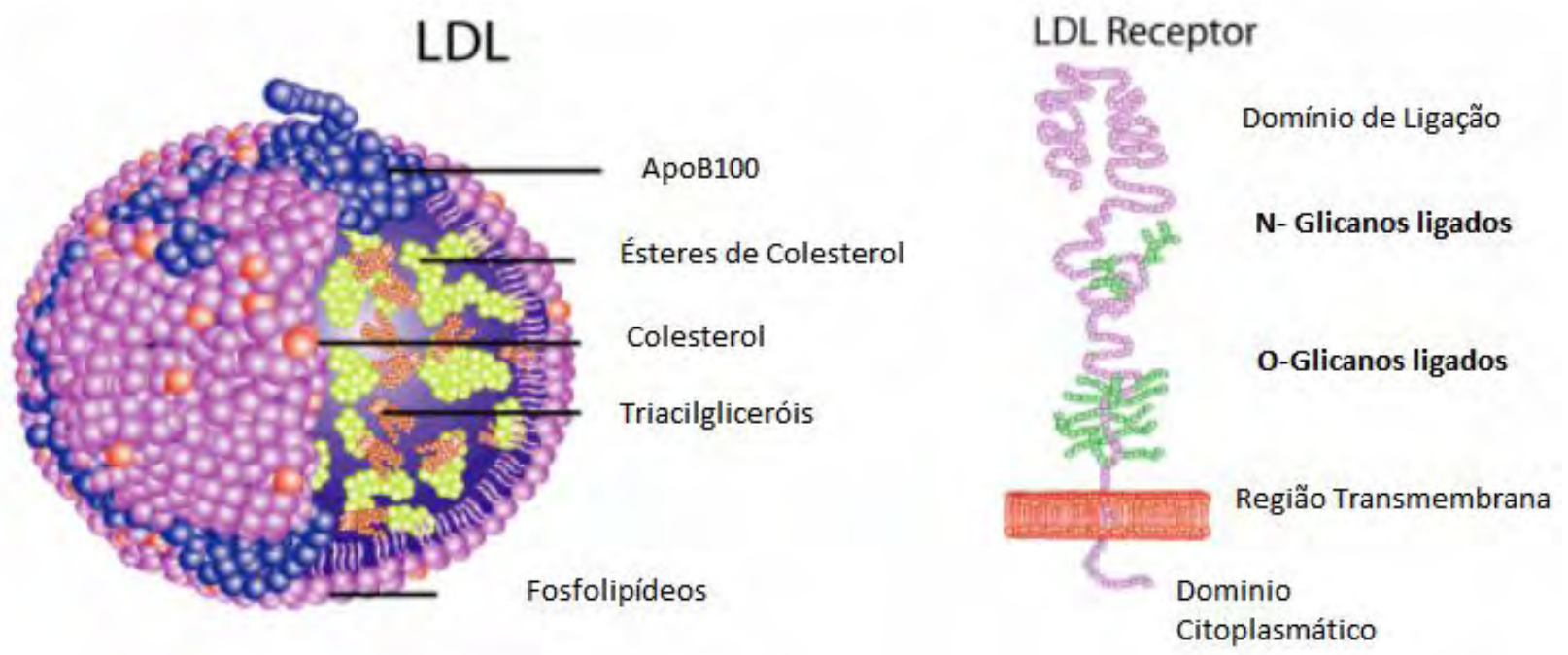

Figura 2. Partículas de LDL (Lipoproteína de Baixa Densidade) e seus componentes; Estrutura da enzima LDL-Receptor (Sigma-Aldrich, 2014).

A LDL é formada da seguinte maneira: após os quilomícrons circulantes serem hidrolisados pela lipoproteína lipase, os quilomícrons remanescentes resultantes são absorvidos pelo fígado, onde seus componentes lipídicos e a recém-sintetizada apolipoproteína B são reagrupados em VLDL nas células hepáticas. A VLDL liberada pelo fígado também é hidrolisada pelas lipases na circulação e através da hidrólise dos triacilgliceróis ocorre a redução do seu teor e diâmetro, perdendo apolipoproteínas C e E para formar a LDL. O principal papel fisiológico da LDL é fornecer o colesterol para os tecidos periféricos, onde é absorvida através do receptor de LDL, que reconhece apolipoproteínas B e E sobre a LDL. Um dos principais mecanismos de regulação do nível de LDL no soro é a absorção celular de LDL da circulação (BROWN; GOLDSTEIN, 1986).

O receptor de lipoproteína de baixa densidade (LDL-r) é uma glicoproteína de superfície celular que desempenha um papel crítico no controle homeostático de colesterol no sangue mediando a remoção de partículas de lipoproteínas contendo colesterol da circulação (BROWN; GOLDSTEIN, 1986) (Figura 2). Este complexo receptor - lipoproteína reconhecem apoproteínas 
B e E por um processo de alta afinidade de ligação e internalização onde removem estas lipoproteínas da circulação, regulando os níveis de colesterol plasmático. Estes receptores localizam-se em regiões da célula, denominadas fossetas revestidas que contêm clatrina (onde estas moléculas receptoras se aglomeram na superfície da célula e no caso da LDL ligam-se a apoB-100 da superfície, internalizando por endocitose para os endossomos, formando-se vesículas endocíticas, que em $\mathrm{pH}$ baixo, dissociam a molécula LDL de seu receptor . O receptor volta à superficie da célula num processo chamado reciclagem, onde irá retomar outro ciclo de endocitose. Os componentes das partículas de LDL são hidrolizados pelos lisossomos, em aminoácidos e colesterol livre, este reutilizado pela célula, associando-se às membranas celulares (JEON; BLACKLOW, 2005).

\subsection{OXIDAÇÃO DOS ÁCIDOS GRAXOS}

A oxidação do colesterol inclui a autoxidação de ácidos graxos insaturados, que por serem extremamente susceptíveis à oxidação, originam principalmente radicais livres e hidroperóxidos que catalisam a formação dos óxidos de colesterol (WASOWICZ, 2003).

O DHA tem um maior número de duplas ligações em comparação ao ácido araquidônico, por isso o DHA é mais suscetível à oxidação mediada por radicais livres (ROBERTS, 1998). De acordo com Smith (1990), a oxidação dos ácidos graxos atinge a porção colesteril do éster de colesterol.

$\mathrm{Na}$ autoxidação de ácidos graxos insaturados os iniciadores são radicais livres em fases distintas, provavelmente produzidos pela decomposição de hidroperóxidos já presentes ou produzidos inicialmente por fotoxidação. A primeira etapa é a de iniciação, onde se descreve a abstração de um hidrogênio, de um carbono do ácido graxo formando o radical de um ácido graxo conhecido como radical alquil. A abstração do hidrogênio ocorre preferencialmente nos átomos de carbono onde há necessidade de baixa energia para a dissociação da ligação C-H. Existem duas etapas clássicas de propagação, uma etapa em que oxigênio é adicionado ao radical alquil (peroxidação) e outra semelhante à etapa de iniciação, envolvendo a transferência de hidrogênio da espécie não radicalar para o peróxido. Inúmeras outras reações podem ocorrer na etapa de propagação, tais como decomposição de hidroperóxidos (pode ser térmica, mas é mais

provável a promoção por traços de íons metálicos que variam seu estado redox) e isomerização 
de peróxidos. Esta fase é comumente catalisada por metais de transição, fase em que a entalpia da reação é mais baixa do que a de iniciação, por isso ocorre mais rapidamente. Na etapa de terminação acontece a formação de espécies não radicais, como aldeídos, cetonas, éteres, alcanos e polímeros combinando-se entre si e formando moléculas estáveis (SMITH, 1987; SMITH; MARCH, 2007; ADHVARYU et al., 2000; ADHVARYU; ERHAN; PEREZ, 2002; PRATT; MILLS; PORTER, 2003; TALLMAN; ROSCHEK; PORTER, 2004; SHAHIDI, 2005.), em situações de pouco oxigênio, por exemplo no caso de óleos de fritura, é susceptível a ocorrência de reações de terminação entre radicais alquil, possibilitando a formação de dímeros de ácidos graxos, cetonas e epóxidos (GORDON, 2001; DAMODARAN; PARKIN; FENNEMA, 2010).

Os ácidos graxos também podem ser oxidados enzimaticamente, a reação é catalisada pelas enzimas lipoxigenase (LOX) e cicloxigenase (COX), ambas possuem átomos de ferro em suas estruturas. A ativação inicial é dada pela oxidação deste átomo de ferro por pequenas quantidades de hidroperóxidos, em seguida a enzima abstrai o grupo metilênico dos ácidos graxos poli-insaturados e o ferro é reduzido, formando-se um complexo radical enzima-peroxi (GORDON, 2001). No mecanismo de catálise da COX, há uma ciclização do radical peroxila, formando um endoperóxido. Em seu mecanismo completo, a COX envolve a redução do grupamento hidroperóxido deste endoperóxido por atividade peroxidásica, já mecanismo de catálise da LOX, o radical peroxila é reduzido a um ânion peróxido e protonado, originando hidroperóxidos (SCHILSTRA et al., 1992; GORDON, 2001).

\subsection{OXIDAÇÃO DO COLESTEROL}

A oxidação do colesterol é desencadeada por alguns fatores como: presença de luz, oxigênio, radiação, calor, metais de transição e ácidos graxos poli-insaturados (PANIANGVAIT et al., 1995 e SMITH, 1996). Óxidos de colesterol referem-se a um grupo de esteróis com estrutura similar à molécula de colesterol que contém grupos cetona, hidroxila, ou grupo epóxido em um dos anéis no núcleo esterol ou na cadeia lateral do grupo hidroxila (MOREL; LIN, 1996; WASOWICZ, 2003).

A oxidação do colesterol pode ocorrer por reações enzimáticas e não enzimáticas, a primeira ocorre no organismo e a segunda pelos alimentos em processos de autoxidação, peroxidação lipídica, oxidação fotoquímica, radiação, calor, metais de transição e ácidos graxos 
poli-insaturados (PANIANGVAIT et al., 1995; GUARDIOLA et al., 1997; SMITH, 1996). A oxidação enzimática do colesterol ocorre por algumas enzimas do citocromo P-450, como colesterol 7 $\alpha$-hidrolase, 26-hidrolase, 7-cetodesidrogenase e 5 $\alpha$, 6 $\alpha$-epoxidase (LEONARDUZZI; SOTTERO; POLI, 2002). A oxidação não enzimática ocorre através do processo de autoxidação através de reações em cadeia que formam radicais livres de forma semelhante à oxidação de lipídios insaturados (SMITH, 1996).

A oxidação do colesterol (Figura 3) pode-se iniciar com a formação de um radical no carbono 7, pela abstração do hidrogênio, ocasionada por radiação ou outros radicais. O radical formado reage com um oxigênio molecular triplete $\left({ }_{2}^{3} \mathbf{0}\right)$ produzindo o radical peroxila, estabilizado pela fixação de um hidrogênio, formando os $7 \alpha$ e $7 \beta$ - hidroperóxicolesterol, estes produtos primários da oxidação do colesterol. Estes dois epímeros encontram-se em equilíbrio, mas com tendência a predominância da forma $\beta$, que é termodinamicamente mais estável. Após a decomposição dos $7 \alpha$ e $7 \beta$ - hidroperóxicolesterol o produto é a formação de seus alcoóis correspondentes o $7 \alpha$ e $7 \beta$ - hidroxicolesterol, a desidrogenação destes produtos ou a desidratação dos $7 \alpha$ e $7 \beta$ - hidroperóxicolesterol resulta no 7-cetocolesterol. O 7-cetocolesterol e os $7 \alpha$ e $7 \beta$ - hidróxicolesterol são produtos secundários da oxidação do colesterol (SMITH, 1990; 1996; NIELSEN et al., 1995).

\subsection{Efeitos Biológicos da Oxidação do Colesterol}

O colesterol está presente em todas as células e regula a fluidez das bicamadas lipídicas. Os produtos de oxidação do colesterol, os oxiesteróis, têm sido vistos como mensageiros de sinalização celular e colesterol de transporte (DICZFALUSY, 2004), sendo considerados como possíveis mediadores de alterações reativas, estruturais e funcionais da parede vascular, as quais são afetadas pelo processo aterosclerótico (LEONARDUZZI; SOTTERO; POLI, 2002). Estes óxidos podem ser componentes da LDL - colesterol que ao ser oxidada exerce potencial efeito aterogênico (BERLINER; HEINECKE, 1996).

No processo inicial de desenvolvimento da aterosclerose ocorre uma modificação da barreira funcional do endotélio vascular, que permite a penetração da LDL e outros constituintes, ativando monócitos para esta área, onde se tornam macrófagos. Os macrófagos degradam a LDL 
internamente, formando células espumosas (GUARDIOLA et al., 1997; BROWN ; JESSUP, 1999).

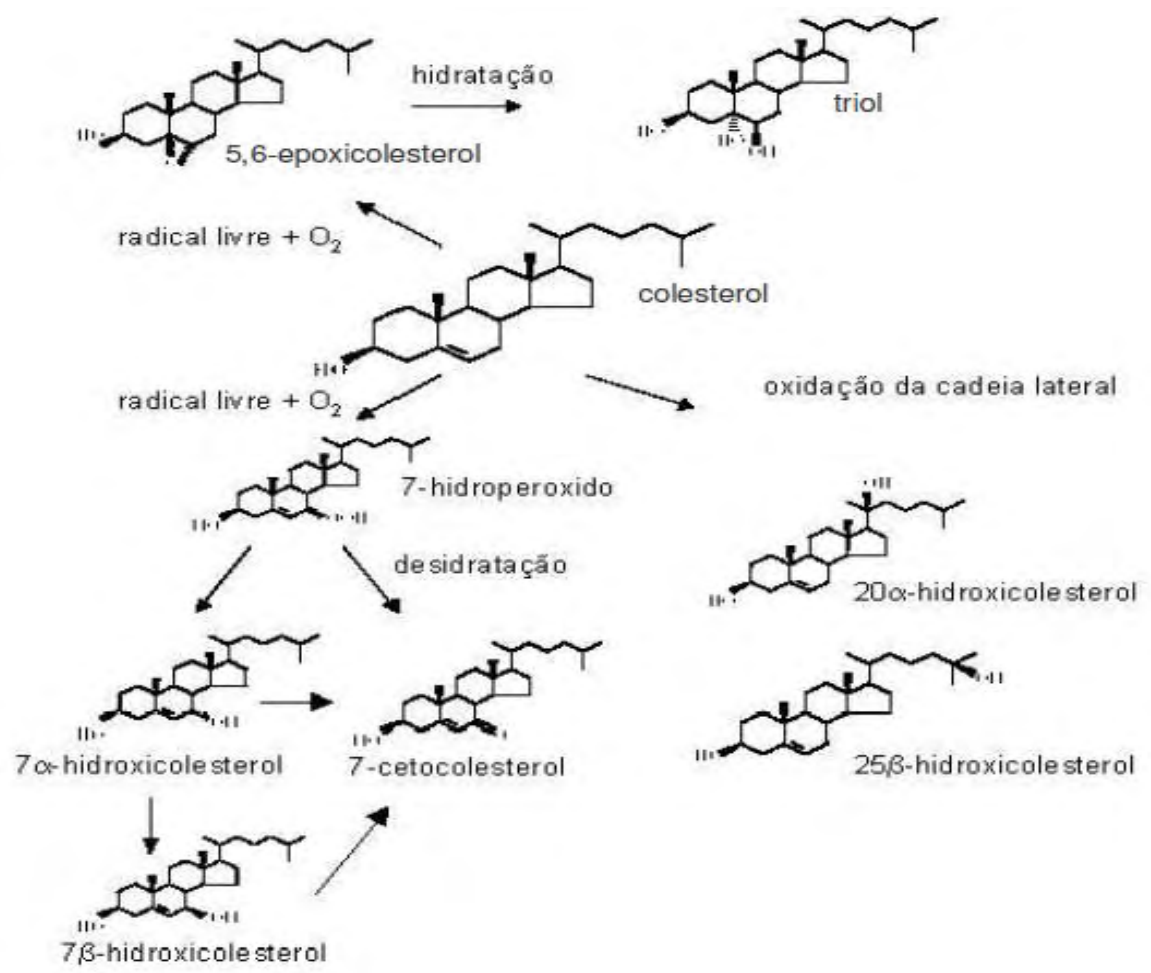

Figura 3. Mecanismos de autoxidação do colesterol (SMITH, 1990; 1996).

O colesterol por ser vulnerável à oxidação, os inúmeros produtos desse processo têm implicações importantes na saúde humana. Estes compostos são documentados como potencialmente citotóxicos, mutagênicos, cancerígenos e associados à promoção da aterosclerose (BROWN; JESSUP, 1999; LEONARDUZZI; SOTTERO; POLI， 2002; LORDAN; MACKRILL;O’BRIEN, 2009; OTAEGUI-ARRAZOLA et al., 2010, OLKKONEN; BÉASLAS; NISSILÄ., 2012). Vários óxidos de colesterol têm sido detectados em quantidades apreciáveis nos tecidos e fluídos biológicos de humanos, incluindo plasma, lipoproteínas aterogênicas e placas ateroscleróticas (BROWN; JESSUP, 1999). Os óxidos mais comuns em alimentos, como o 7-ceto, 25-OH, 7 $\alpha-\mathrm{OH}, 7 \beta-\mathrm{OH}, 5,6 \alpha$-epóxido, 5,6 $\beta$-epóxido e Triol, contêm diferentes graus de aterogenicidade e citotoxicidade (BÖSINGER; LUF; BRANDI, 1993). 
Os óxidos de colesterol estimulam a agregação plaquetária porque inibem as prostaglandinas, estas essenciais para a integridade vascular (RONG et al., 1998; 1999). Estudos utilizando coelhos evidenciaram maior potência dos óxidos de colesterol do que o colesterol, no dano endotelial e formação da placa ateromatosa (IMAI et al., 1980) e efeitos do colestanotriol ao inibir a biossíntese de prostaglandinas nas artérias desses animais (PENG; HU; MORIN, 1991). Porém, alguns óxidos de colesterol têm algumas funções biológicas importantes, garantindo a homeostase do colesterol, com efeitos melhores que o próprio colesterol, como o $7 \alpha-\mathrm{OH}$, que é formado enzimaticamente durante o início da produção de ácidos biliares, e como já se sabe a secreção biliar é o mecanismo de eliminação de muitos esteróis, incluindo o colesterol. Outro exemplo é o 25-OH, que tem um importante papel na modulação da biossíntese do colesterol, inibindo a hidroximetilglutaril-CoA redutase (HMG-CoA redutase) (MOREL; LIN, 1996).

Outros estudos demonstram também a citotoxicidade desses produtos da oxidação do colesterol estimulando o mecanismo de morte celular, a apoptose (BEST et al., 1998) e evidenciaram sua indução na via mitocondrial, nas células endoteliais, células da musculatura lisa e ocasionam necrose de fibroblastos (LIZARD et al., 1999; YAO; TABAS, 2000).

\subsection{EFEITOS DAS FONTES DE ÁCIDOS GRAXOS POLI-INSATURADOS SOBRE A SAÚDE HUMANA}

Os efeitos benéficos dos ácidos graxos Omega 3, ácido eicosapentaenóico (EPA) e ácido docosahexanóico (DHA) foram descritos a primeira vez em esquimós da Groenlândia, que consumiam dietas ricas em peixes e apresentaram baixas taxas de doenças coronárias, asma, diabetes Mellitus tipo 1 e esclerose múltipla. Desde essa observação, os efeitos benéficos dos acidos graxos poli-insaturados principalmente da família n-3 têm se estendido a benefícios relacionados a níveis de lipídios séricos, ação antitrombocitária sobre as plaquetas e proteção contra algumas doenças como o câncer, doença inflamatória intestinal e artrite reumatóide (SIMOPOULOS, 2008a; 2008b; ERKKILA et al., 2008; BROWN; CHUNG; SAWYER, 2010).

Estes ácidos contém maior efeito sobre os lipídios séricos em humanos e animais, reduzindo a concentração de triglicerídeos (TG) nas lipoproteínas de muito baixa densidade (VLDL). As particulas de VLDL, que por serem ricas em TG, sofrem hidrólise pela ação da lipoproteína lipase e passam por interações com outras particulas de lipoproteínas do plasma, originando às 
lipoproteínas de baixa densidade (LDL), que são indesejáveis. As LDL no homem são responsáveis pelo transporte da maior parte de colesterol sérico. Humanos que receberam dietas ricas em ácidos graxos n-3, apresentaram LDL diminuída no plasma, ocorrendo também um aumento das lipoproteínas de alta densidade (HDL), estão desejáveis, já que são responsáveis pelo trasporte reverso do colesterol, onde é feito o transporte dos tecidos periféricos para o fígado (SIMOUPOULOS, 2006; BROWN; CHUNG; SAWYER, 2010).

Dietas ricas em ácidos graxos poli-insaturados da familia n-3 inibem o metabolismo do ácido araquidônico (C20:4N-6), através da competição pelas enzimas elongases e dessaturases como visto anteriormente, este que é o principal substrato para enzimas lipoxigenase (LOX) e cicloxigenase (COX) na biossíntese dos eicosanóides (prostaglandinas, tromboxanas, prostaciclinas e leucotrienos), que apresentam função na aterosclerose, reações imunológicas, alergias e inflamações, considerando que a tromboxana A2 é fortemente proagregatória e vasoconstritora (PARKINSON et al., 1994; VOSS, 2004; TULETA; BAURIEDEL; HASENBANK, 2009).

A ingestão inadequada de Omega-3 em desequilíbrio com Omega-6 ou defeito na dessaturação e/ou alongamento são fatores já conhecidos que influenciam o metabolismo de ácidos graxos poli-insaturados (PUFAs) da família n-3. Na presença de um ou mais destes fatores, a produção dos derivados de cadeias longas de ácido linolénico- $\alpha$ é diminuída (SIMOPOULOS, 2003).

A metabolização do ácido araquidônico pelas enzimas cicloxigenase e lipoxigenase dão origem aos eicosanoides PGE2 e o LTB4, responsáveis por um potencial efeito pró-inflamatório (HAWTHORNE et al., 1990). Já os eicosanóides produzidas a partir do EPA, por exemplo as prostaglandinas da série 3 e LT5, têm efeito inflamatório e proliferativo menor (HARDMAN, 2004).

Da mesma forma em que sugeriu-se que dietas ricas em Omega-3 diminuiam os riscos de algumas doenças em determinadas populações que as consumiam. Por outro lado autores levantaram hipóteses contrárias, expondo que um excesso também pode ser deletério, como no caso dos próprios esquimós em que são observadas altas taxas de mortes acidentais por sangramento (BANG; DYERBERG; NIELSON, 1971) e alta mortalidade por acidente vascular cerebral hemorrágico em comunidades pesqueiras do Japão com dieta semelhante (HIRAI; HAMAZAKI; TERANO, 1980). 


\section{OBJETIVOS}

O objetivo geral deste trabalho foi avaliar os efeitos do fornecimento de rações hipercolesterolêmicas e com diferentes relações de ácidos graxos n-6:ácidos graxos n-3 sobre o teor de colesterol total, LDL-colesterol, HDL-colesterol e triacilgliceróis em sangue, artérias e em tecidos de coelhos.

Os objetivos específicos foram:

- Verificar se a determinação planimétrica de placas lipídicas e o teor de colesterol das mesmas estão relacionados com o desequilíbrio da relação n-6:n-3 na dieta e/ou com a indução da hipercolesterolemia em coelhos;

- Averiguar se o fornecimento da dieta com equilíbrio e desequilíbrio das proporções de n-6:n-3 interrompe ou mesmo regride ou desencadeia a doença aterosclerótica;

- Desenvolver metodologia in vitro para representar os experimentos in vivo, com o objetivo de se investigar a melhor relação de ácidos graxos n-6/ácidos graxos n-3 na prevenção do desenvolvimento da aterosclerose;

- Investigar o efeito dos ácidos graxos sobre a atividade da proteína LDL - receptor no endotélio da aorta em coelhos.

\section{MATERIAIS E MÉTODOS}

\subsection{LOCAL}

O ensaio biológico foi realizado no Biotério Experimental do Campus Administrativo da USP em Pirassununga - SP.

As análises de perfil de ácidos graxos no soro de coelhos foram realizadas no Laboratório de Desenvolvimento de Alimentos Funcionais no Departamento de Alimentos e Nutrição Experimental (LDAF) na Faculdade de Ciências Farmacêuticas da Universidade de São Paulo

A obtenção dos tecidos e preparo dos mesmos foram realizados no Laboratório de Morfofisiologia Molecular e Desenvolvimento (LMMD) e Laboratório de Histologia-ZAB e 
Didático de Anatomia dos Animais Domésticos (ANATOMIA) da Faculdade de Ciências Básicas da USP de Pirassununga.

As análises de ácidos graxos em soro de coelhos e soro fetal bovino de referência foram realizadas no Laboratório de Engenharia de Separações no Departamento de Engenharia de Alimentos (LES) da Universidade de São Paulo.

\subsection{ANIMAIS E RAÇÕES EXPERIMENTAIS}

Foram utilizados 42 coelhos machos em crescimento com peso médio inicial de 2,5Kg, da raça Nova Zelândia, mantidos em gaiolas metálicas individuais, medindo $600 \mathrm{~cm} \mathrm{x} 600 \mathrm{~cm}$ durante todo o experimento. A água foi fornecida ad libitum, utilizando bebedouro tipo Nipple. A ração utilizada foi comercial para coelhos em crescimento, enriquecida com fontes de ácidos graxos poli-insaturados das famílias Omegas.

\subsubsection{Composição centesimal}

O ensaio biológico foi executado num período de 150 dias, dividido em duas fases. A Fase 1 correspondeu a 75 dias de estudo, utilizando animais submetidos às seguintes dietas: com indução de hipercolesterolemia, com desequilíbrio na proporção de n-6:n-3 e vice-versa e balanço na proporção de n-6:n-3 (grupo controle). Foram formados sete ensaios para a Fase 1, com animais adaptados às condições ambientais de estudo por duas semanas, os quais foram divididos aleatoriamente em sete grupos de seis coelhos cada, descritos abaixo:

Grupo A: Animais alimentados com 100g diários de ração e proporção de n-6:n-3 de 4:1;

Grupo B: Animais alimentados com $100 \mathrm{~g}$ diários de ração enriquecida com $0,5 \%$ de colesterol e proporção de n-6:n-3 de 2:1;

Grupo C: Animais alimentados com $100 \mathrm{~g}$ diários de ração enriquecida com 0,5\% de colesterol e proporção de n-6:n-3 de 15:1;

Grupo D: Animais alimentados com 100g diários de ração e proporção de n-6:n-3 de 15:1;

Grupo E: Animais alimentados com $100 \mathrm{~g}$ diários de ração enriquecida com 0,5\% de colesterol e proporção de n-6:n-3 de 1:15;

Grupo F: Animais alimentados com 100g diários de ração e proporção de n-6:n-3 de 1:15; 
Grupo G: Animais alimentados com 100g diários de ração comercial de coelhos.

A dieta hipercolesterolêmica foi preparada dissolvendo-se colesterol em pó (Dolder, Suíça) em etanol, à temperatura de $60^{\circ} \mathrm{C}$, com incorporação imediata à ração e evaporação do etanol. Como fontes de ácidos graxos n-6 e n-3 foram utilizados óleo de girassol e óleo de peixe, respectivamente. A segunda fase correspondeu ao tempo de 75 dias de estudo, sequenciais à Fase 1 (sem interrupção). Os animais remanescentes (três animais de cada grupo) continuaram recebendo as mesmas dietas da Fase 1, exceto no grupo B com indução de hipercolesterolemia (ração comercial enriquecida com $0,5 \%$ de colesterol) que recebeu além desta última o tratamento controle (proporção de n-6:n-3 de 4:1) para verificar o possível efeito benéfico nos parâmetros analisados.

A determinação da composição centesimal das rações utilizou as metodologias oficiais da AOAC (1985). A composição química das rações encontra-se na Tabela 1.

Tabela 1. Composição e níveis nutricionais calculados das dietas experimentais.

\begin{tabular}{lccccccc}
\hline $\begin{array}{l}\text { Ingredientes por } \\
\text { Kg/tonelada }\end{array}$ & Grupo A & $\begin{array}{c}\text { Grupo } \\
\text { B }\end{array}$ & $\begin{array}{c}\text { Grupo } \\
\text { C }\end{array}$ & $\begin{array}{c}\text { Grupo } \\
\text { D }\end{array}$ & $\begin{array}{c}\text { Grupo } \\
\text { E }\end{array}$ & Grupo F & Grupo G \\
\hline Farelo de Arroz & 248 & 248 & 248 & 248 & 248 & 248 & 272 \\
Desengordurado & & & & & & & \\
Farelo de Cascas de & 257 & 263 & 213 & 213 & 152 & 152 & 250 \\
Soja & & & & & & & \\
Farelo de Soja 45.5\% & 98 & 96 & 105 & 105 & 103 & 103 & 91 \\
PB & & & & & & & \\
Farelo de Trigo & 200 & 200 & 214 & 214 & 267 & 267 & 200 \\
Farelo de Glúten de & 100 & 100 & 100 & 100 & 100 & 100 & 100 \\
Milho & & & & & & & \\
Sorgo Moído 8.5\% PB & 59 & 58 & 55 & 55 & 50 & 50 & 61 \\
Fosfato bicálcico & 8 & 8 & 7 & 7 & 7 & 7 & 7 \\
Cálcario 38\% Ca & 15 & 15 & 15 & 15 & 16 & 16 & 15 \\
Óleo de Girassol & 3 & 3 & 3 & 3 & - & - & - \\
Óleo de Peixe & 9 & 5 & 36 & 36 & 53 & 53 & - \\
Colesterol & - & 0,5 & 0,5 & - & 0,5 & - & - \\
Suplemento Vitamínico & 4,0 & 4,0 & 4,0 & 4,0 & 4,0 & 4,0 & 4,0 \\
e Mineral Completo & & & & & & & \\
para Coelhos & & & & & & &
\end{tabular}




\begin{tabular}{|c|c|c|c|c|c|c|c|}
\hline \multicolumn{8}{|c|}{ Nutrientes } \\
\hline Energia Digestívell & 2500 & 2500 & 2500 & 2500 & 2500 & 2500 & 2500 \\
\hline $\mathrm{kcal} / \mathrm{kg}$ & & & & & & & \\
\hline Proteína Bruta \% & 17 & 17 & 17 & 17 & 17 & 17 & 17 \\
\hline Fibra Bruta\% & 15 & 15 & 14 & 14 & 12 & 12 & 15 \\
\hline Extrato etéreo \% & 3 & 3 & 3 & 3 & 2 & 2 & 2 \\
\hline Cálcio \% & 1 & 1 & 1 & 1 & 1 & 1 & 1 \\
\hline Fósforo disponível \% & 0 & 0 & 0 & 0 & 0 & 0 & 0 \\
\hline Fósforo total \% & 1 & 1 & 1 & 1 & 1 & 1 & 1 \\
\hline MetCis Total \% & 1 & 1 & 1 & 1 & 1 & 1 & 1 \\
\hline Metionina Total \% & 0 & 0 & 0 & 0 & 0 & 0 & 0 \\
\hline Lisina Total\% & 1 & 1 & 1 & 1 & 1 & 1 & 1 \\
\hline Sódio \% & 0 & 0 & 0 & 0 & 0 & 0 & 0 \\
\hline Treonina Total \% & 1 & 1 & 1 & 1 & 1 & 1 & 1 \\
\hline Xantofilas mg & 1 & 1 & 1 & 1 & 1 & 1 & 1 \\
\hline
\end{tabular}

\subsection{EUTANÁSIA DOS COELHOS, COLETA DE SANGUE E OBTENÇÃO DO SORO}

\subsubsection{Eutanásia dos Coelhos}

No final da Fase 1 (75 dias) e da Fase 2 (150 dias), três animais (aleatórios) de cada grupo foram eutanasiados. Os coelhos foram anestesiados intramuscularmente com uma mistura de 1 $\mathrm{mL} / \mathrm{kg}$ de peso vivo de quetamina (Virbac, São Paulo) e 0,6 mL/kg de peso vivo de xilasina (Coopers, São Paulo). Após confirmação da sedação, foram aplicados $10 \mathrm{~mL}$ de cloreto de potássio $(\mathrm{KCl})$ por injeção intracardíaca até cessamento total dos sinais vitais.

\subsubsection{Coleta de Sangue}

A coleta do sangue por punção cardíaca, nos coelhos, foi realizada no início do estudo (controle basal) e durante a eutanásia dos coelhos. 


\subsubsection{Obtenção do Soro de Coelhos}

As amostras de sangue foram coletadas de cada animal e centrifugadas a $3000 \mathrm{rpm}$ por 15 minutos a $4^{\circ} \mathrm{C}$ para a obtenção do soro.

\subsection{Perfil de Ácidos Graxos no Soro de Coelhos}

As amostras de soro foram derivatizadas usando a técnica de esterificação direta, como descrito por Shirai et al. (2005) e a composição foi determinada por cromatografia gasosa GC (Agilent 7890 A, Agilent Technologies Inc., Santa Clara, EUA). As condições cromatográficas foram: coluna capilar de sílica fundida (J; W DB-23 Agilent 122-236; 60m x 250 mm de diâmetro interno, hélio foi o gás de arraste, fluxo de $1 \mathrm{~mL} / \mathrm{min}$, com injecção split de 50:1. A programação da temperatura da coluna foi a seguinte: início a $80^{\circ} \mathrm{C}$, com aquecimento de $5^{\circ} \mathrm{C}$ por minuto até $175^{\circ} \mathrm{C}$, seguido por gradiente de $3^{\circ} \mathrm{C}$ por minuto até $230^{\circ} \mathrm{C}$ e mantida nesta temperatura por 5 minutos. A temperatura do injetor e do detector (FID) foram de $250^{\circ} \mathrm{C}$ e $280^{\circ} \mathrm{C}$, respectivamente. Os ácidos graxos foram identificados comparando-se os tempos de retenção com aqueles das quatro misturas purificadas de padrão de ésteres metílicos de ácidos graxos (Sigma Chemical Co.: 4-7801; 47085-U; 49453-U e U-47885). Os resultados foram expressos como \% do total de ácidos graxos.

\subsection{DETERMINAÇÕES DAS LIPOPROTEÍNAS LDL E HDL-COLESTEROL E TRIACILGLICERÓIS}

No soro foi analisado o teor de LDL-colesterol, HDL-colesterol e triacilgliceróis, segundo método enzimático-colorimétrico (Laborlab) e com leitura de absorbâncias em espectrofotômetro $\mathrm{UV}-\mathrm{Vis}$ a $500 \mathrm{~nm}$ para cada item.

\subsection{OBTENÇÃO DOS TECIDOS DA ARTÉRIA AORTA E FÍGADO}


Após os animais serem eutanasiados foi realizada a abertura do tórax para a retirada da artéria aorta, sendo esta dissecada e seccionada em porções para as análises laboratoriais.

O fígado foi retirado da cavidade e fragmentos extraídos a partir de cortes triangulares do lobo esquerdo. Os tecidos foram fixados em solução de formaldeído a 10\% por 24 horas. Após fixação o material foi desidratado em soluções de etanol com concentrações crescentes de 70 a $100 \%$, diafanizado em solvente xilol e posterior impregnação e inclusão em parafina histológica. A partir da seleção dos blocos de parafina foram obtidos cortes sequenciais de $4 \mu \mathrm{m}$ por micrótomo (Leica, modelo RM2125, Alemanha) para análise histopatológica para fígado e artéria e também análise planimétrica e imunohistoquímica para artérias.

\subsubsection{Determinação do Teor de Colesterol Total da Artéria}

Para a determinação de colesterol total na artéria dos coelhos, o método foi desenvolvido baseando-se na metodologia de Mazalli et al., 2003, utilizando cromatografia líquida de alta eficiência (CLAE).

\subsubsection{Determinação Planimétrica de Placas Lipídicas na Artéria Aorta}

A determinação planimétrica de placas lipídicas foi realizada submetendo os cortes de artérias aortas à coloração para lipídeos totais, utilizando-se corante oil-red, sendo posteriormente aderidos em lâminas de vidro e fotografados por microscopia (Microscópio Olympus BX 60 e câmera acoplada Carl Zeiss MC80 DX). As áreas de artérias e placas foram mensuradas utilizando-se o programa Image J. Calcula-se a área da espessura da artéria e da placa de ateroma e o valor é expresso pela média da razão entre gordura/artéria (área).

\subsubsection{Análise Histopatológica de Artéria Aorta e Fígado}

Foi realizada a análise histopatológica dos cortes de fígado e artéria, posteriormente coradas em hematoxilina e eosina (HE). Em fígado, o alvo foi a identificação de patologias como 
esteatose e cirrose e suas localizações e em artérias placas ateromatosas, bem como o grau de acometimento.

\subsubsection{Análise da Expressão Gênica da LDL-Receptor por Imunohistoquímica em Artérias no Período Total}

A técnica de imunohistoquímica baseou-se no reconhecimento de antígenos por determinados anticorpos. O princípio dos métodos utilizados foi através da identificação de antígenos celulares ou teciduais por uma reação antígeno - anticorpo, onde a reação foi visualizada por moléculas reveladoras, como enzimas e fluorocromos, por exemplo. Neste estudo, utilizou-se a imunohistoquímica para identificar e compreender a distribuição e a localização de proteínas expressas em diversas partes do organismo dos animais estudados.

Para a realização da imunohistoquímica foram seccionados os tecidos de artéria a partir do material emblocado em parafina histológica e aderidos em lâminas de vidro silanizadas (StarFrost Adhäsiv-Silan, Knittel, Alemanha), desparafinizados em banhos de xilol e reidratados em solução decrescente de etanol (de 100 a 70\%) e por fim lavados em água corrente. Após a etapa de desparafinização as lâminas foram acondicionadas em cubas de vidro contendo tampão citrato $(0,384 \mathrm{~g}$ de ácido cítrico monohidratado; $2,352 \mathrm{~g}$ de citrato de sódio tribásico diidratado; $1 \mathrm{~L}$ de água destilada, $\mathrm{pH}$ 6,0) por duas vezes de 20 minutos cada em forno de microondas, para a recuperação antigênica. $\mathrm{O}$ bloqueio da atividade de peroxidase tecidual endógena foi realizado por incubação em solução de peróxido de hidrogênio a 5\% por duas vezes de 20 minutos cada, posteriormente lavadas em solução tampão TBS $10 \%$ por três vezes de 5 minutos cada. Para o bloqueio de ligações inespecíficas, os cortes foram incubados com soro de cabra a $10 \%$ em TBS por 1 hora. Para a identificação da proteína LDL - Receptor foi utilizado o anticorpo Anti LDL-Receptor antibody (Rabbit polyclonal to LDL-Receptor - Abcam ab30532) O anticorpo primário foi diluído na proporção de 1:50 utilizando tampão TBS com 1\% de soro de cabra e adicionados $50 \mu \mathrm{l}$ em cada lâmina, cortes contendo anticorpo irrelevante para controle de isotipo (IgG) (Anti Rabbit IgG monoclonal - Abcam ab99702) na concentração 1:25 também foram incubados (50 $\mu 1$ em cada lâmina) overnight a $4^{\circ}$ em câmara úmida. Após a incubação com anticorpo primário, foram feitas lavagens dos cortes com tampão TBS contendo $1 \%$ de soro de cabra. Em seguida, foi utilizado o kit polivalente Dako-advance HRP Link (Dako, EUA), 
seguindo as recomendações do fabricante, para que fosse verificada a reação e lavagem em tampão TBS.

A revelação das lâminas realizou-se com o substrato cromógeno diaminobenzidina (Liquid DAB + substrate, Chromogen System, cat\# K3468, DAKOCytomation, USA). Posteriormente, os cortes foram contra-corados com hematoxilina, desidratados e diafanizados e a montagem de lâminas realizada para análise sob microscopia de luz.

A análise do anticorpo anti-LDL - receptor foi pelo método de Remmele e Stegnerl (1987). Após a análise, as marcações foram ranqueadas pela porcentagem de células positivas por campo (negativo $=0 ; 1-25 \%=1 ; 26-50 \%=2 ; 51-75 \%=3 ;$ e $76-100 \%=4$ ), e também pela intensidade (negativa $=0$, baixa $=1$, moderada $=2$ e intensa $=3$ ). Ao final, essas mensurações (porcentagem e intensidade) foram multiplicadas por esses níveis para a realização da análise estatística.

\subsection{DETERMINAÇÃO IN VITRO DA MELHOR RELAÇÃO DE ÁCIDOS GRAXOS N- 6/ÁCIDOS GRAXOS N-3}

Foi desenvolvida metodologia in vitro para avaliar a melhor relação de ácidos graxos n6/ácidos graxos n-3 na prevenção do desenvolvimento da aterosclerose segundo o delineamento experimental demonstrado em seguida:

\subsubsection{Isolamento das Células Endoteliais}

A partir da retirada da artéria aorta dos coelhos, foi realizado o procedimento de isolamento das células endoteliais a partir do seguinte protocolo:

A artéria recebeu lavagem do lúmen com solução salina tamponada (PBS) e foi preenchida com o meio de cultivo Iscove's Modified Dulbecco's Medium, IMDM (Gibco BRL, Grand Island, NY, EUA) suplementado com soro fetal bovino SFB (Sigma-Aldrich, St Louis, MO, USA) e antibióticos. Em seguida, foi preenchida com colagenase tipo 1 (Sigma-Aldrich, St Louis, MO, USA) na concentração de $0,5 \%$ e colocada em estufa a $37^{\circ} \mathrm{C}$ e $5 \%$ de $\mathrm{CO}_{2}$ por 15 minutos juntamente com mais duas placas de Petri contendo $500 \mu \mathrm{L}$ de meio de cultivo IMDM. Posteriormente, houve coleta das células do interior da artéria que foram transferidas para um 
microtubo e neste adicionou-se $1 \mathrm{~mL}$ de meio de cultivo IMDM, para ser centrifugado a 1200 rpm por 5 minutos. Após o descarte do sobrenadante, foi adicionando de 50 a $100 \mu \mathrm{L}$ de meio IMDM, sendo homogeneizado e distribuído em duas placas. A suspensão celular foi incubada na estufa a $37^{\circ} \mathrm{C}$ e após 24 horas foi acrescentado $750 \mu \mathrm{L}$ de meio de cultivo IMDM em cada placa. Após 24 horas o meio foi substituído e foi acrescentado $2 \mathrm{~mL}$ de IMDM contendo $20 \mu \mathrm{L}$ de suplemento celular Endothelial Cell Growth Supplement (ECGS) (SigmaAldrich, St Louis, MO, USA) e estocadas por dez dias em estufa, sendo o meio trocado no quinto dia. As células foram então congeladas a $-80^{\circ} \mathrm{C}$ com $1 \mathrm{~mL}$ do seguinte meio: $5 \mathrm{~mL}$ IMDM, $0,5 \mathrm{~mL}$ do crioprotetor dimetilsulfóxido (DMSO, 10\%) e $1 \mathrm{~mL}$ de soro fetal bovino SFB $(20 \%)$.

\subsubsection{Crescimento e Repicagem das Células}

Nas células foram adicionados 2 mL de IMDM e então após centrifugação a 3000 rpm por 15 minutos o sobrenadante foi descartado para adição de $40 \mu \mathrm{L}$ de ECGS e estocados na estufa a $37^{\circ} \mathrm{C}$. Para a repicagem das células o meio foi trocado a cada 48 horas num período total de 15 dias, obtendo-se um total de $60 \times 10^{5}$ células em $1000 \mu \mathrm{L}$ que foram divididas em 10 placas que receberam $2 \mathrm{~mL}$ de IMDM e foram estocadas na estufa a $37^{\circ} \mathrm{C}$.

\subsubsection{Determinação de Ácidos Graxos no Soro de Coelhos e Soro Fetal Bovino de Referência}

As condições de análise utilizadas para a determinação de ácidos graxos em soro de coelhos (extração por metodologia descrita anteriormente) e soro fetal bovino de referência (Gibco, EUA) foram por cromatografia gasosa de ésteres metílicos de ácidos graxos de acordo com a metodologia oficial 1-62 da AOCS (1998), utilizando um cromatógrafo gasoso (Shimaszu, modelo GC 2010 AF, Japão) com detector de ionização de chama e coluna SP-2560 0.2 $\mu \mathrm{m}, 100$ $\mathrm{m} \times 0.25 \mathrm{~mm}$ i.d. (Supelco); hélio como gás de arraste na taxa de 1,12 $\mathrm{mL} / \mathrm{min}$; temperatura do injetor de $250^{\circ} \mathrm{C}$; temperatura da coluna de $140^{\circ} \mathrm{C}(5 \mathrm{~min}),(140$ a 240$){ }^{\circ} \mathrm{C}\left(\right.$ taxa de $\left.4{ }^{\circ} \mathrm{C} / \mathrm{min}\right)$ e $240^{\circ} \mathrm{C}(15 \mathrm{~min})$; temperatura do detector de $250^{\circ} \mathrm{C}$. Os ésteres metílicos dos ácidos graxos foram identificados por comparação com os tempos de retenção dos padrões Supelco 37 (PA, EUA) e a 
quantificação foi realizada por normalização interna, sendo o tempo total de análise de 45 minutos.

A composição de ácidos graxos em soro $(\mathrm{g} / 100 \mathrm{~g})$ de coelho e soro fetal bovino encontram-se na Tabela 2.

Tabela 2. Maior composição de ácidos graxos em soro (g/100g).

\begin{tabular}{lcc}
\hline Ácidos Graxos & Soro de Coelho & Soro Fetal Bovino \\
\hline C18:2 cis 9,12 n-6 Linoleico & 30,51 & 21,86 \\
C20:4n-6 5,8,11,14 Araquidônico & 1,50 & 1,14 \\
\hline$\Sigma \mathrm{n}-6$ & 32,01 & 23,00 \\
\hline
\end{tabular}

Não foram encontrados valores de ácidos graxos poliinsaturados da família n-3 nos soros analisados. A partir desses resultados foram determinadas as concentrações utilizadas no Teste Dose-Resposta descrito a seguir.

\subsubsection{Teste Dose-Resposta Induzido por Ácido Graxo Poli-insaturado Omega-3 em Células Endoteliais de Coelhos}

Esse experimento foi realizado para obtenção de dose-resposta utilizando óleo de peixe de uma marca comercial com 180mg/g de ácido docosahexaenóico (DHA) e 120mg/g de ácido eicosapentaenóico (EPA) totalizando 300mg/g de Omega 3. Um total de dez placas com células endoteliais receberam óleo de peixe comercial e/ou soro de coelho e soro bovino de referência, apenas as células das placas nove e dez foram o controle (sem adição de óleo de peixe). Em oito tubos de centrífuga, enumerados de um a oito foram adicionados em cada um $500 \mu \mathrm{L}$ de meio de IMDM e procedeu-se à diluição seriada do óleo de peixe como descrita a seguir: No primeiro tubo houve adição de $500 \mu \mathrm{L}$ de óleo de peixe e o conteúdo foi fortemente homogeneizado. No segundo tubo, houve adição de $500 \mu \mathrm{L}$ do conteúdo do primeiro com seguida homogeneização, sendo realizado este procedimento de diluição até o tubo de número oito. As concentrações de Omega-3 adicionadas nos soros de coelho e bovino variaram de 0,00030 a $0,0000023 \mathrm{mg} / \mathrm{mg}$, respectivamente. As concentrações de Omega- 6 adicionadas nos soros de coelho foram 0,000032 a $0,00000025 \mathrm{mg} / \mathrm{mg}$ e bovino foram 0,000023 a $0,000000175 \mathrm{mg} / \mathrm{mg}$, respectivamente (Tabela 3 ). 
Tabela 3. Dose de Omega-3 e Omega-6 em células endoteliais de coelhos.

\begin{tabular}{ccccc}
\hline & \multicolumn{2}{c}{ Soro de Coelho $(\mathrm{mg} / \mathrm{mg})$} & \multicolumn{2}{c}{ Soro Fetal Bovino $(\mathrm{mg} / \mathrm{mg})$} \\
\hline $\begin{array}{c}\text { Placas com } \\
\text { células }\end{array}$ & Omega-3 & Omega-6 & Omega-3 & Omega-6 \\
\hline 1 & $3 \times 10^{-4}$ & $3,2 \times 10^{-5}$ & $3 \times 10^{-4}$ & $2,3 \times 10^{-5}$ \\
2 & $1,5 \times 10^{-4}$ & $1,6 \times 10^{-5}$ & $1,5 \times 10^{-4}$ & $1,15 \times 10^{-5}$ \\
3 & $7,5 \times 10^{-5}$ & $8 \times 10^{-6}$ & $7,5 \times 10^{-5}$ & $5,7 \times 10^{-6}$ \\
4 & $3,75 \times 10^{-5}$ & $4 \times 10^{-6}$ & $3,75 \times 10^{-5}$ & $2,8 \times 10^{-6}$ \\
5 & $1,87 \times 10^{-5}$ & $2 \times 10^{-6}$ & $1,87 \times 10^{-5}$ & $1,4 \times 10^{-6}$ \\
6 & $9,3 \times 10^{-6}$ & $1 \times 10^{-6}$ & $9,3 \times 10^{-6}$ & $7 \times 10^{-7}$ \\
7 & $4,6 \times 10^{-6}$ & $5 \times 10^{-7}$ & $4,6 \times 10^{-6}$ & $3,5 \times 10^{-7}$ \\
8 & $2,3 \times 10^{-6}$ & $2,5 \times 10^{-7}$ & $2,3 \times 10^{-6}$ & $1,75 \times 10^{-7}$ \\
\hline
\end{tabular}

\subsubsection{Extração e Quantificação de RNA e DNA}

Para a extração de DNA e RNA das amostras, foi utilizado o reagente Trizol (Invitrogen, Califórnia, USA) seguindo o protocolo de extração do fabricante. Para a determinação das concentrações de DNA e RNA e seu grau de pureza, foi utilizado o espectrofotômetro (NanoDrop 2000c UV-Vis Spectrophotometer Thermo Scientific, Wilmington, USA). As concentrações foram determinadas pela absorbância de $260 \mathrm{~nm}$ e a pureza foi determinada pelo cálculo da relação de absorbância a 260 e 280 nm

\subsubsection{Potencial de Membrana Mitocondrial}

O Teste de Potencial de Membrana Mitocondrial foi realizado por citômetria de fluxo para demonstrar a viabilidade celular através da capacidade de um corante fluorescente específico se ligar à mitocôndria de células viáveis (JOHNSON, 1980). Após cinco dias, as placas com a células foram retiradas da estufa, receberam tripsina para o descolamento das células e após centrifugação foram ressuspendidas em $1 \mathrm{~mL}$ de meio IMDM. Em cada tubo de $15 \mathrm{~mL}$ contendo 
as células, foram adicionados 2,5 $\mu \mathrm{L}$ de corante Mitotracker Red (Invitrogen, Califórnia, USA). O conteúdo do tubo nove (controle) foi dividido em dois tubos, um recebeu o corante denominado controle positivo, e o outro não, denominado controle negativo. Todo o material foi novamente colocado na estufa e a cada 5 minutos foi promovida agitação manual de todas as amostras num período total de 30 minutos e o citômetro de fluxo utilizado foi um BD FACSAria $^{\mathrm{TM}}$ II e o software o FACSDiva (BDBiosciences, Brazil).

\subsection{ANÁLISE ESTATÍSTICA}

Os resultados obtidos foram analisados com auxílio do software STATISTICA versão 12 (StatSoft, 2014) as médias comparadas pelo teste de Tukey, ao nível de 5\% de probabilidade.

\subsubsection{Estatística da Análise de Imunohistoquímica}

Para a estatística da análise de imunohistoquímica foi utilizando o software ASSISTAT (SILVA; AZEVEDO, 2006) e as médias comparadas foram submetidas a correlação simples pelo Teste $\mathrm{t}$, ao nível de $5 \%$ de probabilidade.

\section{RESULTADOS E DISCUSSÕES}

\subsection{PERFIL DE ÁCIDOS GRAXOS NO SORO DE COELHOS}

Segundo os resultados da Tabela 4, não houve diferença significativa no perfil de ácidos graxos entre os períodos experimentais.

No período de 75 dias, para o total de ácidos graxos saturados, os maiores teores foram observados no tratamento F (n-6:n-3 de 1:15) e menores nos tratamentos B (0,5\% de colesterol e n-6:n-3 de 2:1), C (0,5\% de colesterol e n-6:n-3 de 15:1) e D (n-6:n-3 de 15:1). No total de ácidos 
graxos poli-insaturados n-3, o maior valor foi no tratamento $E(0,5 \%$ de colesterol e n-6:n-3 de $1: 15)$ e menores nos tratamentos $C(0,5 \%$ de colesterol e n-6:n-3 de 15:1) e G (comercial).

Tabela 4. Resultados do Perfil de Ácidos Graxos em soro de coelhos no período de 75 dias de experimento.

\begin{tabular}{|c|c|c|c|c|c|c|c|}
\hline \multirow[t]{2}{*}{ Ácidos Graxos } & \multicolumn{7}{|c|}{ Tratamentos $(75 \text { dias })^{a}$} \\
\hline & $\mathbf{A}$ & $\mathbf{B}$ & $\mathbf{C}$ & $\mathbf{D}$ & $\mathbf{E}$ & $\mathbf{F}$ & $\mathbf{G}$ \\
\hline C14:0 & $1,29 a b$ & $0,61 \mathrm{ab}$ & $0,59 \mathrm{~b}$ & $1,20 \mathrm{ab}$ & $0,76 a b$ & $1,07 \mathrm{ab}$ & $1,92 \mathrm{a}$ \\
\hline C15:0 & $0,59 \mathrm{ab}$ & $0,51 \mathrm{abc}$ & $0,42 \mathrm{c}$ & $0,47 \mathrm{abc}$ & $0,42 \mathrm{abc}$ & $0,58 \mathrm{ab}$ & $0,63 a$ \\
\hline C16:0 & $23,64 \mathrm{a}$ & $25,24 \mathrm{a}$ & $22,77 \mathrm{ab}$ & $19,56 b$ & $21,50 \mathrm{ab}$ & $25,18 \mathrm{a}$ & $25,65 \mathrm{a}$ \\
\hline C17:0 & $0,62 \mathrm{ab}$ & $0,62 \mathrm{ab}$ & $0,53 \mathrm{ab}$ & $0,48 b$ & $0,52 \mathrm{ab}$ & $0,70 \mathrm{a}$ & $0,73 \mathrm{ab}$ \\
\hline C18:0 & $12,54 \mathrm{a}$ & $10,85 \mathrm{a}$ & $11,12 \mathrm{a}$ & $10,25 \mathrm{a}$ & $8,71 \mathrm{a}$ & $12,01 \mathrm{a}$ & $11,77 \mathrm{a}$ \\
\hline C16:1n7cis & $0,43 b$ & $0,36 b$ & $0,35 b$ & $0,59 b$ & $0,32 \mathrm{a}$ & ND & ND \\
\hline C16:1n9cis & $0,97 b$ & $2,19 a$ & $1,28 \mathrm{ab}$ & $0,68 b$ & $1,79 \mathrm{abc}$ & $1,74 \mathrm{c}$ & $1,49 \mathrm{abc}$ \\
\hline C18:1n9trans & $1,16 \mathrm{a}$ & $0,84 \mathrm{a}$ & $1,14 \mathrm{a}$ & $1,54 \mathrm{a}$ & $0,75 \mathrm{a}$ & $0,98 \mathrm{a}$ & $1,41 \mathrm{a}$ \\
\hline C18:1n9cis & $19,44 \mathrm{ab}$ & $16,52 \mathrm{ab}$ & $18,09 \mathrm{ab}$ & $17,97 \mathrm{ab}$ & $14,53 b$ & $14,97 b$ & $21,21 \mathrm{a}$ \\
\hline C18:1n7 & $0,86 b$ & $1,43 \mathrm{a}$ & $0,94 b$ & $0,69 b$ & $1,50 \mathrm{a}$ & $1,41 \mathrm{a}$ & $1,18 \mathrm{ab}$ \\
\hline C18:2n-6trans & $0,30 \mathrm{bc}$ & $0,22 \mathrm{bcd}$ & $0,42 b$ & $0,75 \mathrm{a}$ & $0,13 \mathrm{c}$ & ND & ND \\
\hline C18:2n-6c & $30,58 b c$ & $29,85 b$ & $33,25 \mathrm{ab}$ & $36,91 \mathrm{a}$ & $20,29 d$ & $18,62 d$ & $29,94 b c$ \\
\hline C18:3n-3 & $0,89 \mathrm{a}$ & $1,06 \mathrm{a}$ & $0,76 a$ & $0,85 \mathrm{a}$ & $0,93 a$ & ND & ND \\
\hline C20:3n-3 & $0,74 \mathrm{ab}$ & $0,28 b$ & $0,37 b$ & $0,69 \mathrm{ab}$ & $0,17 b$ & $1,11 \mathrm{a}$ & ND \\
\hline C20:4n-6 & $1,78 \mathrm{a}$ & $2,79 a$ & $2,47 \mathrm{a}$ & $1,80 \mathrm{a}$ & $2,58 \mathrm{a}$ & $2,82 \mathrm{a}$ & $1,99 \mathrm{a}$ \\
\hline C20:5 n-3-EPA & $0,45 b$ & $0,42 b$ & $0,27 b$ & $0,54 b$ & $7,27 \mathrm{a}$ & $6,85 a$ & ND \\
\hline C22:5 n-3-DPA & $0,52 b$ & $0,61 b$ & $0,44 b$ & $0,44 b$ & $2,92 \mathrm{a}$ & $2,24 \mathrm{a}$ & ND \\
\hline C22:6 n-3-DHA & $0,95 b$ & $0,95 b$ & $0,84 b$ & $1,01 b$ & $7,05 \mathrm{a}$ & ND & ND \\
\hline Total SAT & $39,09 b$ & $38,15 b c$ & $35,71 b c$ & $32,00 \mathrm{c}$ & $32,29 b$ & $47,58 \mathrm{a}$ & $40,03 b$ \\
\hline POLIN-3 & $3,52 \mathrm{c}$ & $3,22 \mathrm{c}$ & $2,52 \mathrm{~cd}$ & $2,72 \mathrm{c}$ & $18,40 \mathrm{a}$ & $10,19 b$ & $0,35 \mathrm{~d}$ \\
\hline POLIN-6 & $32,36 a b$ & $32,77 \mathrm{ab}$ & $35,77 \mathrm{ab}$ & $38,71 \mathrm{a}$ & $23,06 \mathrm{c}$ & $21,44 \mathrm{c}$ & $31,93 b$ \\
\hline MONO & $21,82 \mathrm{a}$ & $21,79 \mathrm{a}$ & $21,46 a$ & $19,61 \mathrm{a}$ & $19,77 \mathrm{a}$ & $18,25 \mathrm{a}$ & $24,13 \mathrm{a}$ \\
\hline
\end{tabular}




\begin{tabular}{|c|c|c|c|c|c|c|c|}
\hline & \multicolumn{7}{|c|}{${\text { Tratamentos }(150 \text { dias })^{a}}^{a}$} \\
\hline & $\mathbf{A}$ & B & $\mathbf{C}$ & D & $\mathbf{E}$ & $\mathbf{F}$ & $\mathbf{G}$ \\
\hline C14:0 & $0,96 a b$ & $1,01 \mathrm{a}$ & $0,46 b$ & $0,82 \mathrm{ab}$ & $0,94 \mathrm{ab}$ & $1,08 \mathrm{a}$ & $1,38 \mathrm{a}$ \\
\hline C15:0 & $0,51 \mathrm{a}$ & $0,53 a$ & $0,41 \mathrm{a}$ & $0,49 \mathrm{a}$ & $0,45 \mathrm{a}$ & $0,58 \mathrm{a}$ & ND \\
\hline C16:0 & $24,18 \mathrm{ab}$ & $25,71 \mathrm{ab}$ & $23,81 \mathrm{ab}$ & $21,33 b$ & $22,87 \mathrm{ab}$ & $22,91 \mathrm{ab}$ & $26,94 a$ \\
\hline C17:0 & $0,66 \mathrm{a}$ & $0,72 \mathrm{a}$ & $0,53 \mathrm{a}$ & $0,66 \mathrm{a}$ & $0,52 \mathrm{a}$ & $0,62 \mathrm{a}$ & ND \\
\hline C18:0 & $12,73 \mathrm{ab}$ & $13,72 \mathrm{a}$ & $10,74 b$ & $14,12 \mathrm{a}$ & $9,75 b$ & $10,03 b$ & $13,07 \mathrm{a}$ \\
\hline C16:1n7cis & ND & ND & ND & ND & ND & ND & ND \\
\hline C16:1n9cis & $1,07 b$ & $1,73 b c$ & $1,05 \mathrm{bc}$ & $0,83 \mathrm{c}$ & $2,05 \mathrm{a}$ & $2,14 \mathrm{a}$ & $2,12 \mathrm{a}$ \\
\hline C18:1n9trans & $0,98 b$ & $1,58 \mathrm{a}$ & $0,79 b c$ & $1,29 \mathrm{abc}$ & $0,79 b$ & $0,84 b c$ & $1,86 \mathrm{a}$ \\
\hline C18:1n9cis & $17,02 b$ & $18,12 \mathrm{abc}$ & $16,42 b c$ & $18,46 \mathrm{abc}$ & $15,43 b c$ & $15,40 b c$ & $21,52 \mathrm{a}$ \\
\hline C18:1n7 & $0,84 b$ & $1,03 b$ & $0,92 b$ & $0,77 b$ & $1,58 \mathrm{a}$ & $1,52 \mathrm{a}$ & $1,00 \mathrm{~b}$ \\
\hline C18:2n-6trans & $0,47 \mathrm{a}$ & $0,46 \mathrm{a}$ & $0,33 b$ & $0,54 \mathrm{a}$ & $0,18 b$ & $0,42 \mathrm{ab}$ & ND \\
\hline C18:2n-6cis & $32,45 a$ & $25,98 \mathrm{a}$ & $33,58 \mathrm{a}$ & $33,84 \mathrm{a}$ & $20,87 \mathrm{a}$ & $48,84 a$ & $27,07 \mathrm{a}$ \\
\hline C18:3n-3 & $1,10 \mathrm{a}$ & $0,94 \mathrm{a}$ & $0,68 b$ & $0,79 \mathrm{a}$ & $0,93 \mathrm{a}$ & $0,91 \mathrm{a}$ & $1,19 \mathrm{a}$ \\
\hline C20:3n-3 & $1,10 \mathrm{a}$ & $0,92 \mathrm{ab}$ & $0,30 \mathrm{bc}$ & $1,00 \mathrm{ab}$ & $0,25 \mathrm{c}$ & $0,76 a b c$ & $1,22 \mathrm{abc}$ \\
\hline C20:4n-6 & $1,98 \mathrm{a}$ & $2,08 \mathrm{a}$ & $2,99 \mathrm{a}$ & $2,03 \mathrm{a}$ & $2,07 \mathrm{a}$ & $2,96 a$ & $1,82 \mathrm{a}$ \\
\hline C20:5 n-3-EPA & $0,60 \mathrm{~b}$ & $0,34 b$ & $0,25 b$ & ND & $6,20 \mathrm{a}$ & $7,52 \mathrm{a}$ & ND \\
\hline C22:5 n-3-DPA & $0,55 \mathrm{c}$ & $0,42 \mathrm{c}$ & $0,59 \mathrm{c}$ & ND & $2,73 a$ & $2,35 b$ & ND \\
\hline C22:6 n-3-DHA & $1,22 b$ & $0,99 b$ & $0,95 b$ & $1,21 b$ & $5,49 \mathrm{a}$ & ND & ND \\
\hline Total SAT ${ }^{*}$ & $39,31 \mathrm{ab}$ & $42,12 \mathrm{a}$ & $36,29 \mathrm{ab}$ & $37,19 \mathrm{ab}$ & $35,24 b$ & $42,34 \mathrm{ab}$ & $41,39 \mathrm{ab}$ \\
\hline POLI n-3* & $3,40 \mathrm{~b}$ & $3,32 b$ & $2,69 b$ & $3,00 \mathrm{~b}$ & $15,59 \mathrm{a}$ & $11,59 a$ & $0,80 \mathrm{c}$ \\
\hline POLI n-6* & $34,43 \mathrm{ab}$ & $28,09 b$ & $36,63 a$ & $35,87 \mathrm{a}$ & $23,05 \mathrm{c}$ & $24,84 \mathrm{bc}$ & $28,88 b$ \\
\hline MONO* & $19,05 b$ & $21,35 \mathrm{ab}$ & $19,71 \mathrm{ab}$ & $20,07 \mathrm{ab}$ & $20,43 a b$ & $19,06 b$ & $24,30 \mathrm{a}$ \\
\hline
\end{tabular}

${ }^{a}$ Médias e desvio padrão $\mathrm{n}=3$. Valores seguidos de mesma letra minúscula em cada linha e maiúscula em cada coluna não diferem (P> 0.05). ND (não determinado). ${ }^{\mathrm{b}}$ Tratamentos: A (n-6:n-3 de 4:1); B (0,5\% de colesterol e n-6:n-3 de 2:1; C (0,5\% de colesterol e n-6:n3 de 15:1; D (n-6:n-3 de 15:1); E (0,5\% de colesterol e n-6:n-3 de 1:15; F ( n-6:n-3 de 1:15) e G (ração comercial de coelho). *SAT (saturados), POLIN (poli-insaturados), MONO (monoinsaturados). 
Nos valores totais de ácidos graxos polinsaturados n-6, os maiores foram nos tratamentos A (n-6:n-3 de 4:1), B (0,5\% de colesterol e n-6:n-3 de 2:1), C (0,5\% de colesterol e n-6:n-3 de 15:1) e D (n-6:n-3 de 15:1) e os menores nos tratamentos E (0,5\% de colesterol e n-6:n-3 de 1:15) e F (n-6:n-3 de 1:15). Entre os monoinsaturados não houve diferença significativa. Em relação aos principais ácidos graxos da família Omega, o C18:2 n-6 cis (ácido linoleico), foram maiores nos tratamentos $C(0,5 \%$ de colesterol e n-6:n-3 de 15:1) e D (n-6:n-3 de 15:1), menor no F (n6:n-3 de 1:15) e não houve diferença significativa para o C20:4 n-6 (ácido araquidônico).

Nos da família n-3, C20:5 n-3 (ácido eicosapentaenóico, EPA), C22:5 n-3 (ácido docosapentaenóico, DPA), C22:6 n-3 (ácido docosahexaenóico, DHA), os maiores valores foram nos soros dos coelhos alimentados com o maior nível destes, nas dietas (tratamentos E $(0,5 \%$ de colesterol e n-6:n-3 de 1:15) e F (n-6:n-3 de 1:15).

No período de 150 dias, para o total de ácidos graxos saturados, o maior teor foi observado no tratamento $B(0,5 \%$ de colesterol e n-6:n-3 de $2: 1)$ e menor no $E(0,5 \%$ de colesterol e n-6:n-3 de 1:15). Nos totais de ácidos graxos poli-insaturados n-3, os maiores valores foram nos tratamentos E (0,5\% de colesterol e n-6:n-3 de 1:15) e F (n-6:n-3 de 1:15) e menor no tratamento $\mathrm{G}$ (comercial). Nos totais de ácidos graxos poli-insaturados $n-6$, os maiores valores foram nos tratamentos A (n-6:n-3 de 4:1), C (0,5\% de colesterol e n-6:n-3 de 15:1) e D (n-6:n-3 de 15:1) e menores nos tratamentos $\mathrm{E}(0,5 \%$ de colesterol e n-6:n-3 de 1:15) e F (n-6:n-3 de 1:15). Entre os monoinsaturados, os menores valores foram nos tratamentos A (n-6:n-3 de 4:1) e F (n-6:n-3 de 1:15). Em relação aos principais ácidos graxos da família Omega 6, C18:2 n-6 cis (ácido linoleico) não diferiu entre os tratamentos, assim como o C20:4 n-6 (ácido araquidônico). Nos ácidos graxos da família n-3, C20:5 n-3 (ácido eicosapentaenóico, EPA), C22:5 n-3 (ácido docosapentaenóico, DPA), C22:6 n-3 (ácido docosahexaenóico, DHA) também foram maiores nos tratamentos E (0,5\% de colesterol e n-6:n-3 de 1:15) e F (n-6:n-3 de 1:15). No geral, o perfil de ácidos graxos correspondeu diretamente com a dieta consumida pelos coelhos (Tabela 4).

Ishii et al. (1984) compararam uma dieta hipercolesterolêmica (1\% de colesterol) e uma dieta comercial (controle) em coelhos de 1 a 3 meses e os níveis de ácidos graxos no plasma, observaram aumento do ácido araquidônico C20:4 n-6 e diminuição do ácido docosaexanóico C22:6 n-3 pertencente à familia n-3, respectivamente, semelhante ao presente estudo, onde ocorreu a redução do total de ácidos graxos poli-insaturados n-3 quando os coelhos receberam ração comercial. 
Ihara-Watanabe et al. (2000) suplementaram ratos com fonte de ácido linoleico conjugado cis-9, trans-11 (CLA/ n-6) e ácido $\alpha$-linolênico (LNA/ n-3), durante sete dias, nenhuma grande diferença foi encontrada, porém ambos apresentaram maior concentração de n-6, apesar do curto tempo em que se realizou o experimento. Foi sugerido que o ácido $\alpha$-linolênico pode não ser incorporado tão eficientemente pelas moléculas de fosfolipídios e lipoproteínas.

Balková et al. (2009) utilizaram camundongos como modelo experimental para comparar ácidos graxos saturados, monoinsaturados e poli-insaturados, suplementando os animais durante dez semanas com ração sem gordura, enriquecida com $10 \%$ de gordura suína no primeiro grupo, $10 \%$ de óleo de peixe como fonte de n-3 no grupo 2 e óleo de milho como fonte de n-6 no grupo 3. Ao serem analisados no soro dos camundongos, observou-se que houve um decréscimo dos ácidos graxos saturados e monoinsaturados a favor dos poli-insaturados na seguinte sequência: gordura suína > óleo de peixe > óleo de milho.

\subsection{TEOR DE COLESTEROL TOTAL, LDL-COLESTEROL, HDL-COLESTEROL E TRIACILGLICERÓIS EM SORO DE COELHOS}

Os resultados de colesterol total, LDL-colesterol, HDL-colesterol e triacilgliceróis em soro de coelhos encontram-se na Tabela 5.

No período de 75 dias os maiores teores de colesterol total foram nos tratamentos B (0,5\% de colesterol e n-6:n-3 de 2:1), C (0,5\% de colesterol e n-6:n-3 de 15:1) e E (0,5\% de colesterol e n-6:n-3 de 1:15). Porém, no período de 150 dias houve redução do teor de colesterol total no soro dos coelhos do tratamento B (0,5\% de colesterol e n-6:n-3 de 2:1) que passaram a receber o tratamento A (n-6:n-3 de 4:1), refletindo também no menor teor de LDL-colesterol.

No geral, os maiores teores de colesterol total e das demais lipoproteínas foram nos tratamentos B (0,5\% de colesterol e n-6:n-3 de 2:1), C (0,5\% de colesterol e n-6:n-3 de 15:1) e E (0,5\% de colesterol e n-6:n-3 de 1:15), no período de 75 dias com posterior diminuição apenas no tratamento B (0,5\% de colesterol e n-6:n-3 de 2:1), no período de 150 dias. Em ambos os períodos, os coelhos que receberão ração comercial (tratamento G) apresentaram valores reduzidos de triacilgliceróis e consequentemente de VLDL sendo o mesmo observado no tratamento A, onde foram determinados os menores teores de colesterol total e LDL-colesterol no maior período de experimento. 
Tabela 5. Teor médio de colesterol total, LDL-colesterol, HDL-colesterol e triacilgliceróis (mg/dL) em soro de coelhos nos períodos de 75 dias e 150 dias de experimento.

Período experimental de 75 dias $^{\mathrm{a}}$

\begin{tabular}{|c|c|c|c|c|c|}
\hline Tratamentos $^{\mathrm{b}}$ & Colesterol Total & LDL-colesterol & HDL-colesterol & Triacilgliceróis & VLDL \\
\hline A & $53 \mathrm{Ab}$ & $20 \mathrm{Ab}$ & $17 \mathrm{Ab}$ & $81 \mathrm{Ac}$ & $16 \mathrm{Ab}$ \\
\hline B & $1180 A a$ & $52 \mathrm{Ab}$ & $1002 \mathrm{Aa}$ & 630Aa & $126 \mathrm{Aa}$ \\
\hline $\mathrm{C}$ & $535 \mathrm{Bab}$ & $28 \mathrm{Bb}$ & $436 \mathrm{Ab}$ & $356 \mathrm{Ab}$ & $71 \mathrm{Aab}$ \\
\hline $\mathrm{D}$ & $78 \mathrm{Ab}$ & $36 \mathrm{Ab}$ & $29 \mathrm{Ab}$ & $67 \mathrm{Ac}$ & $13 \mathrm{Ac}$ \\
\hline $\mathrm{E}$ & $1055 \mathrm{Aa}$ & $222 \mathrm{Ba}$ & $705 \mathrm{Aa}$ & 638Aa & $128 \mathrm{Aa}$ \\
\hline $\mathrm{F}$ & $45 \mathrm{Bb}$ & $26 \mathrm{Bb}$ & $9 \mathrm{Ab}$ & $52 \mathrm{Bcd}$ & $10 \mathrm{Bbc}$ \\
\hline $\mathrm{G}$ & $33 \mathrm{Ab}$ & $8 \mathrm{Bc}$ & $17 \mathrm{Ab}$ & $40 \mathrm{Ad}$ & $8 \mathrm{Abc}$ \\
\hline \multicolumn{6}{|c|}{ Período experimental de 150 dias $^{\mathrm{a}}$} \\
\hline Tratamentos $^{\mathrm{b}}$ & Colesterol Total & LDL-colesterol & HDL-colesterol & Triacilgliceróis & VLDL \\
\hline A & $23 \mathrm{Bb}$ & $6 \mathrm{Bc}$ & $1 \mathrm{Bc}$ & $82 \mathrm{Ac}$ & $16 \mathrm{Abc}$ \\
\hline B & $168 \mathrm{Bb}$ & $27 \mathrm{Bb}$ & $126 \mathrm{Bb}$ & 77Bcd & $15 \mathrm{Bc}$ \\
\hline $\mathrm{C}$ & 773Aa & 251Aa & $463 \mathrm{Aa}$ & 294Bb & $59 \mathrm{Ba}$ \\
\hline $\mathrm{D}$ & $33 \mathrm{Bb}$ & $19 \mathrm{Bb}$ & $2 \mathrm{Bc}$ & $62 \mathrm{Ad}$ & $12 \mathrm{Ac}$ \\
\hline $\mathrm{E}$ & $975 \mathrm{Ba}$ & $308 \mathrm{Aa}$ & $572 \mathrm{Ba}$ & $473 \mathrm{Ba}$ & $95 \mathrm{Aa}$ \\
\hline $\mathrm{F}$ & $78 \mathrm{Ab}$ & $54 \mathrm{Ab}$ & $3 \mathrm{Bc}$ & $104 \mathrm{Ac}$ & $21 \mathrm{Ab}$ \\
\hline G & $20 \mathrm{Bb}$ & $17 \mathrm{Ab}$ & $1 \mathrm{Bc}$ & $26 \mathrm{Be}$ & $5 \mathrm{Ad}$ \\
\hline
\end{tabular}

${ }^{a}$ Médias e desvio padrão $\mathrm{n}=3$. Valores seguidos de mesma letra maiúscula em cada linha e minúscula em cada coluna não diferem (P>0.05). ND (não determinado). ${ }^{b}$ Tratamentos: A (n-6:n-3 de 4:1); B (0,5\% de colesterol e n-6:n-3 de 2:1); C (0,5\% de colesterol e n-6:n-3 de 15:1); D (n-6:n-3 de 15:1); E (0,5\% de colesterol e n-6:n-3 de 1:15); F (n6:n-3 de 1:15) e G (ração comercial de coelho).

Um dos principais efeitos dos ácidos graxos poli-insaturados n-3 sobre os lipídios séricos é a redução parcial de triacilgliceróis nas lipoproteínas de muito baixa densidade (VLDL), pela inibição hepática da secreção destes triacilgliceróis nas VLDL e/ou também pelo próprio decréscimo da síntese hepática dos triacilgliceróis (HARRIS; BULCHANDANI, 2006), que após hidrólise dão origem às lipoproteínas de baixa densidade (LDL), que são indesejáveis, por serem responsáveis pelo transporte da maior parte do colesterol sérico. Esse mecanismo de redução na síntese de triacilgliceróis nas VLDL parece estar associado com o decréscimo na transcrição de 
fatores que controlam a expressão de enzimas responsáveis pela formação dos triacilgliceróis dentro dos hepatócitos e pela própria oxidação do ácido graxo (HARRIS et al., 2009). Os níveis de LDL plasmáticas de indivíduos tratados com dietas ricas em PUFA n-3, são diminuídos. Oposto a isso, ocorre o aumento do colesterol das lipoproteínas de alta densidade (HDL), estas que são desejáveis, por serem responsáveis pelo transporte de colesterol dos tecidos periféricos para o fígado, conhecido como transporte reverso do colesterol (SIMOPOULOS, 2006; BROWN; CHUNG; SAWYER., 2010).

Embora no presente estudo não foi evidenciado o aumento de HDL associado aos tratamentos A (n-6:n-3 de 4:1), E (0,5\% de colesterol e n-6:n-3 de 1:15) e F (n-6:n-3 de 1:15), ricos nestes ácidos em comparação aos demais. Resultado semelhante foi observado por Ribeiro Jorge et al. (1997), onde não houve interferência nos níveis de HDL colesterol, porém houve redução dos triacilgliceróis e aumento de colesterol e VLDL com o fornecimento de dieta hipercolesterolêmica $(0,5 \%$ colesterol $)$ e $2 \%$ de gordura de coco, com administração de 300 mg/dia de Omega 3 nos últimos 15 dias totalizando 30 dias de experimento, embora em um período bem inferior em relação ao nosso estudo.

Chen et al. (1992) dividiu coelhos em três grupos: grupo 1: ração comercial (controle); grupo $2: 1 \%$ de colesterol e grupo 3:1\% de colesterol + óleo de peixe. O experimento durou apenas seis semanas, mas já apresentou como resultado no perfil lipídico dos animais um aumento significativo dos lipídios séricos nos animais do grupo 2 e para os animais do grupo 3, houve redução significativa (exceto de LDL) dos teores de triacilgliceróis, colesterol total e HDL.

Parwaresch et al. (1978) ofereceram dieta suplementada com colesterol a 3\%, durante 12 semanas. Os animais que receberam ração comercial não apresentaram diferenças no perfil lipídico, já os animais da dieta hipercolesterolêmica obtiveram elevação maciça da LDLcolesterol desenvolvendo também lesões ateroscleróticas graves.

Bo-qing zhu et al. (1988) ofereceram dietas com quantidades crescentes de colesterol e óleo de peixe nas concentrações $1 \mathrm{~mL}$ (contendo 180mg/EPA e 120mg/ DHA), 2mL (310mg/EPA e $240 \mathrm{mg} / \mathrm{DHA})$ e $3 \mathrm{~mL}$ (540mg/EPA e $360 \mathrm{mg} / \mathrm{DHA})$, durante dez semanas, o colesterol total aumentou em todos os grupos, porém sem diferença significativa entre os três grupos. Apesar de a dose média ministrada no citado estudo ser bem inferior ao nosso trabalho, ocorreu diminuição dos triacilgliceróis, sendo sugerido pela inibição da VLDL ou dos triacilgliceróis. Por outro lado, Shimamura e Wilson (1991), após suplementarem ratos em períodos superiores, ou seja, de 12 e 
18 meses com óleo de peixe e de milho (6\% em ambos), demonstraram significativa redução do colesterol plasmático e triacilgliceróis no grupo que recebeu óleo de peixe em comparação ao que recebeu óleo de milho.

Harris, Connor e McMurray (1983) relataram que seres humanos com uma dieta suplementada com óleo de salmão apresentaram diminuição de triacilgliceróis no plasma de 77 para $48 \mathrm{mg} / \mathrm{dL}$, enquanto que o teor de ácidos graxos n-3 aumentou de 1 para 30\% no plasma.

\subsection{TEOR DE COLESTEROL TOTAL E DETERMINAÇÕES PLANIMÉTRICAS DE PLACAS LIPÍDICAS NA ARTÉRIA AORTA EM COELHOS}

Os resultados de colesterol total em artérias e análise planimétrica das artérias de coelhos encontram-se na Tabela 6.

Tabela 6. Teor de colesterol total e determinação planimétrica em artérias de coelhos nos períodos de 75 e 150 dias de experimento.

\begin{tabular}{|c|c|c|c|c|}
\hline Tratamentos $^{\mathrm{b}}$ & \multicolumn{2}{|c|}{ CT Artérias $(\mathrm{mg} / \mathrm{g})^{\mathrm{c}}$} & \multicolumn{2}{|c|}{ Ateromas $\left(\mu \mathrm{m}^{2}\right)^{\mathrm{d}}$} \\
\hline \multicolumn{5}{|c|}{ Médias \pm desvio padrão } \\
\hline & 75 dias & 150 dias & 75 dias & 150 dias \\
\hline $\mathrm{A}$ & $\mathrm{ND}^{\mathrm{e}}$ & ND & $\mathrm{NM}^{\mathrm{f}}$ & NM \\
\hline $\mathrm{B}$ & $0,0035 \pm 0,00008 \mathrm{Bb}$ & $0,38 \pm 0,03 \mathrm{Ab}$ & 0,21 & 6,70 \\
\hline $\mathrm{C}$ & $0,0062 \pm 0,001 \mathrm{Ba}$ & $1,64 \pm 0,28 \mathrm{Aa}$ & 1,42 & 6,81 \\
\hline $\mathrm{D}$ & $0,0023 \pm 0,0002 \mathrm{Bbc}$ & $0,48 \pm 0,02 \mathrm{Ab}$ & NM & NM \\
\hline $\mathrm{E}$ & $0,0015 \pm 0,001 \mathrm{Bc}$ & $0,57 \pm 0,2 \mathrm{Ab}$ & 2,30 & 11,10 \\
\hline $\mathrm{F}$ & $0,0020 \pm 0,0002 \mathrm{Bc}$ & $0,22 \pm 0,06 \mathrm{Ab}$ & NM & NM \\
\hline $\mathrm{G}$ & $0,00191 \pm 0,0003 \mathrm{Bc}$ & $0,15 \pm 0,03 \mathrm{Ab}$ & NM & NM \\
\hline
\end{tabular}

\footnotetext{
${ }^{a}$ Médias e desvio-padrão de $n=3$. Valores seguidos de mesma letra minúscula em cada coluna e maiúscula em cada linha não diferem (P>0.05). ${ }^{\mathrm{b}}$ Tratamentos: A (n-6:n-3 de 4:1); B (0,5\% de colesterol e n-6:n-3 de 2:1; C $(0,5 \%$ de colesterol e n-6:n-3 de 15:1; D (n-6:n-3 de 15:1); E (0,5\% de colesterol e n-6:n-3 de 1:15; F(n-6:n-3 de 1:15) e G (ração comercial de coelho). ${ }^{\mathrm{c}} \mathrm{CT}$ : Colesterol Total. ${ }^{\mathrm{d}}$ (somatório: espessura da artéria/área da placa lipídica), ${ }^{\mathrm{e}} \mathrm{ND}$ (não determinado), ${ }^{\mathrm{f}} \mathrm{NM}$ : não mensurado.
}

O maior teor de colesterol total foi observado no tratamento $C(0,5 \%$ de colesterol e n-6: n-3 de 15:1) tanto no período de 75 dias quanto no período total experimental de 150 dias. Os menores teores foram nos tratamentos D (n-6:n-3 de 15:1), E (0,5\% de colesterol e n-6:n-3 de 
1:15), F ( n-6:n-3 de 1:15) e G (ração comercial) no período de 75 dias. No período de 150 dias o tratamento $C(0,5 \%$ de colesterol e n-6:n-3 de 15:1) também foi maior em relação aos demais.

Apesar dos animais remanescentes do tratamento B (0,5\% de colesterol e n-6:n-3 de 2:1) terem recebido o tratamento A (n-6:n-3 de 4:1) nos 75 dias restantes de experimento, não houve redução do colesterol total nas artérias. Provavelmente, pelo fato de que o desenvolvimento da aterosclerose inicia-se com a modificação da barreira funcional do endotélio vascular que permite a penetração da LDL-colesterol e uma vez desencadeando este processo, torna-se crônico, progressivo e sistêmico. Por outro lado, a diferenciação, proliferação e apoptose das células da musculatura lisa localizada na camada íntima arterial são modificações que ocorrem no início das lesões ateroescleróticas, quando a enfermidade ainda é reversível (CAMPBELL; CAMPBELL, 1994).

De acordo com os resultados da determinação planimétrica (Tabela 6), foram mensurados ateromas nos tratamentos B (0,5\% de colesterol e n-6:n-3 de 2:1), C (0,5\% de colesterol e n-6: n3 de 15:1) e E (0,5\% de colesterol e n-6:n-3 de 1:15), e estes foram de crescimento significativo até o final do experimento.

É fato que o elevado consumo de ácidos graxos n-6 em detrimento de ácidos graxos n-3 ocasiona o desenvolvimento de doença degenerativa como a aterosclerose (MAYNERISPERXACHS et al., 2010), em adição, o excesso de ácidos graxos n-6 promove a oxidação da lipoproteína de baixa densidade (LDL) que transporta o colesterol para os tecidos periféricos e é responsável pela severidade dos danos causados nas artérias coronárias (GIRAO et al., 2008). Ao contrário, os ácidos graxos Omega 3 foram relacionados com estabilização de placas ateroscleróticas (CALDER, 2004).

A extensão e o tipo da lesão aterosclerótica em coelhos são proporcionais à concentração do colesterol plasmático (BOCAN et al., 1993). No presente estudo, observa-se também que o desequilíbrio tanto em ácidos graxos n-6 como em n-3 contribuíram para a formação das placas. No tratamento A, onde a proporção é de 4:1 entre os ácidos graxos n-6:n-3, respectivamente, não foram observadas lesões significativas. Em estudo semelhante, Chen et al. (1999) induziu coelhos machos à dieta hipercolesterolêmica (1\% de colesterol) e $10 \%$ óleo de peixe, durante seis semanas, observando aumento significativo das lesões nos animais que receberam a dieta contendo apenas colesterol e atenuação das lesões nos grupos que receberam juntamente com o colesterol (0.3\%), o óleo de peixe e/ou vitamina E. 
Bo-Qing Zhu et al. (1988) descreveram que quando forneceram aos coelhos uma dose de óleo de peixe de $2 \mathrm{~mL}$ (contendo 310mg/EPA e 240mg/DHA), durante 10 semanas, houve maior eficácia na redução da aterosclerose. Comparando com os resultados obtidos em nosso estudo, pode-se afirmar que onde houve grandes alterações no desenvolvimento das placas nos tratamentos com excesso de n-6 e n-3. Os efeitos redutores foram inexistentes, talvez por efeito imunossupressor no caso de maior quantidade de n-3 e esperados efeitos deletérios quando os tratamentos continham elevadas concentrações de n-6, mas ambos associados à adição de colesterol nestes.

Parwaresch, Haacke e Mäder (1978) ofereceram dieta suplementada com colesterol a 3\%, durante 12 semanas, para coelhos e obtiveram aumento significativo nas lesões ateroscleróticas severas em relação ao grupo de controle suplementado com ração comercial. O resultado mostrou que em média 57\% da área de superfície aórtica foi afetada. Echeverri et al., 2013, fornecendo dieta hipercolesterolêmica (1\%) para coelhos, durante três meses, apresentou o desenvolvimento de aterosclerose avançada, com deposição de colesterol, formação nuclear lipídica e cápsula fibroblástica. Esses estudos mostram que mesmo com porcentagens pequenas de colesterol administradas e independente do tempo, todos os grupos submetidos apresentaram lesões ateroscleróticas, apenas o estudo de Parwaresch, Haacke e Mäder (1978) descreveu que os coelhos utilizados eram machos. Sabe-se que as fêmeas apresentam fatores hormonais que dificultam a formação de placas ateroscleróticas, porém não foi o caso em nenhum dos estudos. Shimamura e Wilson (1991) suplementaram camundongos com 6\% de óleo de peixe e óleo de milho em dieta comercial durante dois períodos de 12 e 18 meses, observando uma redução significativa nas placas de ateroma dos animais que receberam óleo de peixe com relação aos que receberam óleo de milho.

As figuras representando um animal de cada tratamento, onde foram mensuradas as artérias e placas de ateroma estão nas Figuras de 4 a 10 mostradas a seguir: 


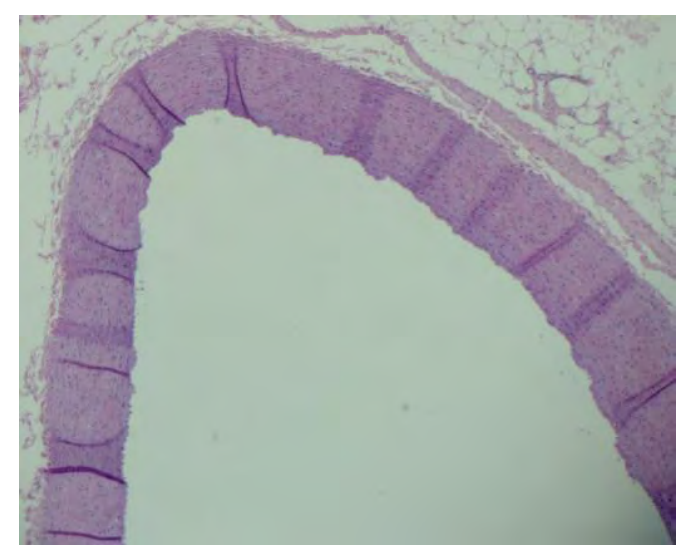

Figura 4. Determinação planimétrica das placas de ateroma e artérias de coelhos - Tratamento A.

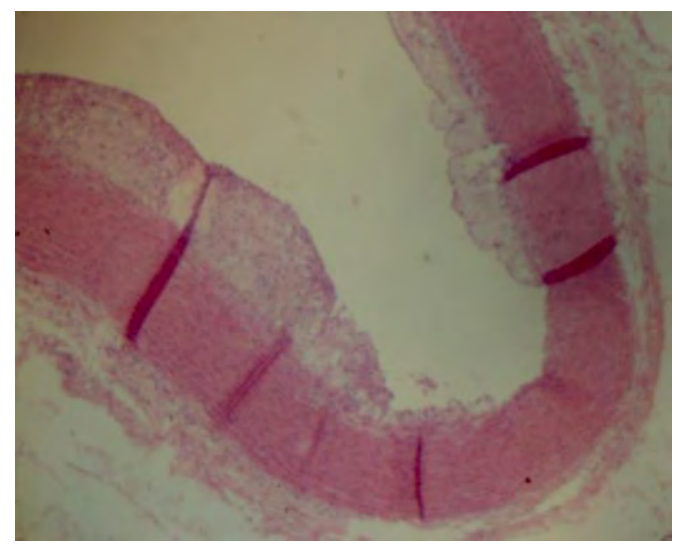

Figura 5. Determinação planimétrica das placas de ateroma e artérias de coelhos - Tratamento B

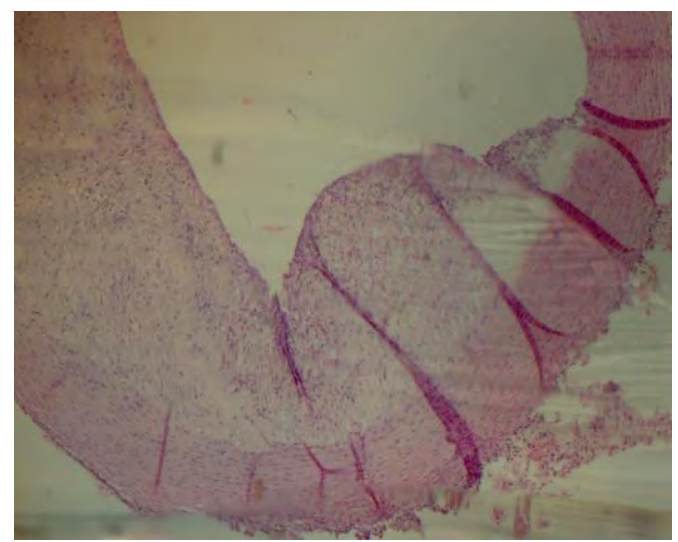

Figura 6. Determinação planimétrica das placas de ateroma e artérias de coelhos - Tratamento C 


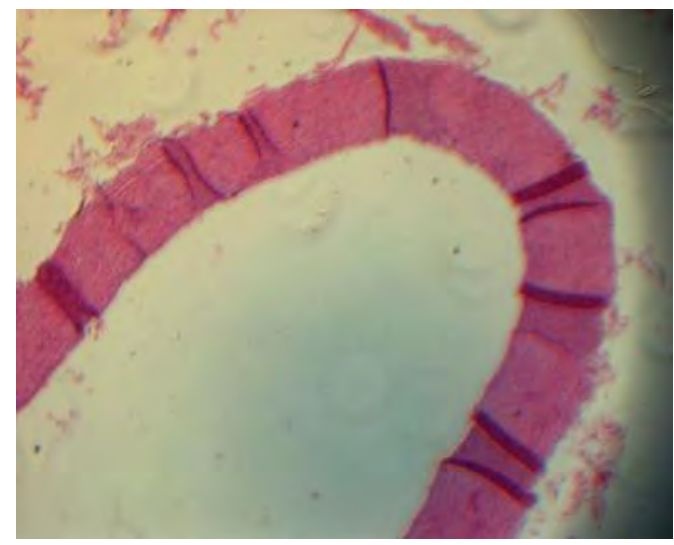

Figura 7. Determinação planimétrica das placas de ateroma e artérias de coelhos - Tratamento D

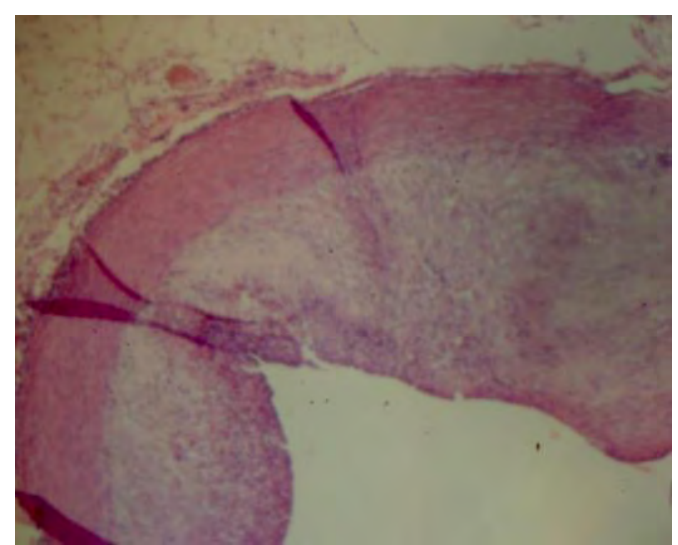

Figura 8. Determinação planimétrica das placas de ateroma e artérias de coelhos - Tratamento E

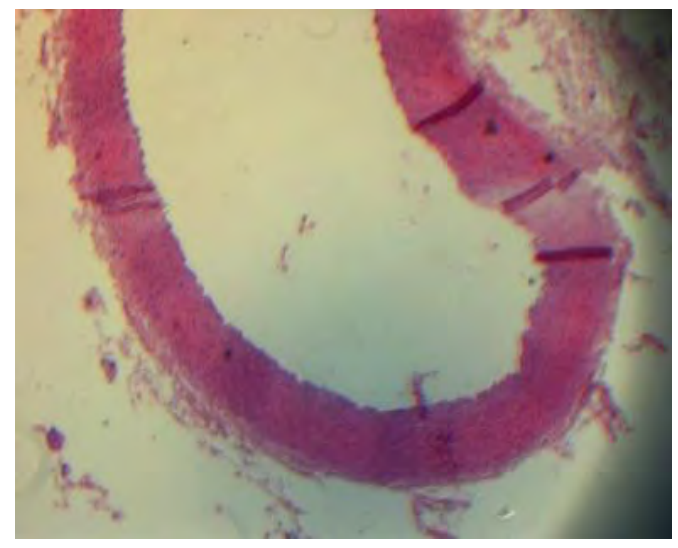

Figura 9. Determinação planimétrica das placas de ateroma e artérias de coelhos - Tratamento F. 


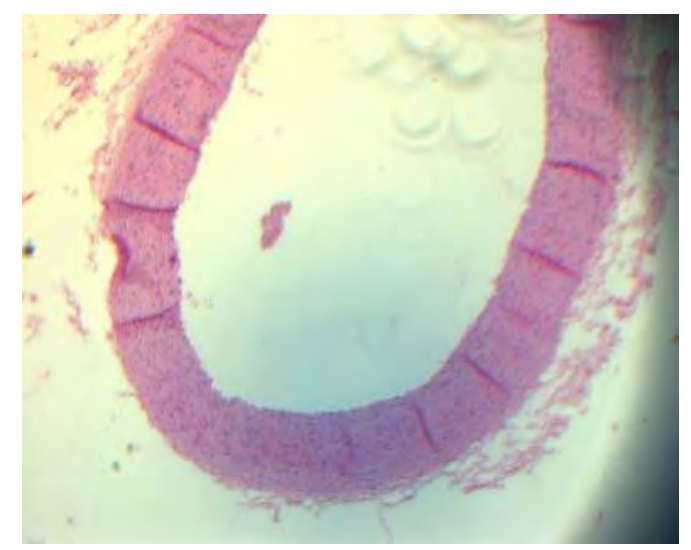

Figura 10. Determinação planimétrica das placas de ateroma e artérias de coelhos - Tratamento G

\subsection{DETERMINAÇÕES HISTOPATOLÓGICAS EM ARTÉRIA E FÍGADO EM COELHOS}

Os resultados das análises histopatológicas em artérias e fígados de coelhos referentes aos dois períodos de tratamento 1 (75 dias) e 2 (150) encontram-se nas Tabelas 7 e 8 , respectivamente.

No geral, houve maior severidade de lesões tanto no fígado quanto nas artérias no maior período experimental (Tabela 8). Observou-se que no tratamento A (n-6:n-3 de 4:1) hepatite crônica periportal leve em aproximadamente $33 \%$ dos coelhos, em artérias nada digno de nota em $100 \%$ dos coelhos. No tratamento B (0,5\% de colesterol e n-6:n-3 de 2:1), houve esteatose centro lobular de leve a moderada presente em $83 \%$ dos coelhos, sendo que no segundo período houve evolução para hepatite crônica em 33\% dos coelhos, no caso das artérias, observaram-se placas ateromatosas em $100 \%$ deles. No tratamento $C$ (0,5\% de colesterol e n-6: n-3 de 15:1), foi observado esteatose em $100 \%$ dos coelhos, sendo que $67 \%$ centro lobular e médio zonal e $50 \%$ microgoticular difusa com presença de fibrose, além das artérias terem apresentado placas ateromatosas em $100 \%$ dos animais. 
Tabela 7. Determinações histopatológicas em artérias e tecidos em coelhos no período de 75 dias.

\begin{tabular}{|c|c|c|c|c|c|c|}
\hline \multirow{2}{*}{$\begin{array}{c}\text { Tratamentos } \\
{ }^{\mathbf{a}} \mathbf{A} \\
\end{array}$} & \multicolumn{6}{|c|}{ Coelhos } \\
\hline & 1 & 2 & 3 & 4 & 5 & 6 \\
\hline FÍGADO & NDN & NDN & NDN & NDN & NDN & NDN \\
\hline ARTÉRIA & NDN & NDN & NDN & NDN & NDN & NDN \\
\hline \multicolumn{7}{|l|}{$\mathbf{B}$} \\
\hline FÍGADO & Esteatose (+) & NDN & Esteatose $(++)$ & NDN & Esteatose $(++)$ & NDN \\
\hline ARTÉRIA & Placa (+) & NDN & Placa (+) & NDN & Placas $(+/++)$ & NDN \\
\hline \multicolumn{7}{|l|}{$\mathbf{C}$} \\
\hline FÍGADO & Esteatose (+) & NDN & NDN & NDN & $\begin{array}{c}\text { Esteatose micro/ } \\
\text { macrogotícular } \\
(+++)\end{array}$ & NDN \\
\hline ARTÉRIA & Placa (+) & Placas (+) & NDN & NDN & Placa $(+/++)$ & NDN \\
\hline \multicolumn{7}{|l|}{$\mathbf{D}^{\mathbf{a}}$} \\
\hline FÍGADO & NDN & NDN & NDN & NDN & NDN & NDN \\
\hline ARTÉRIA & NDN & NDN & NDN & NDN & NDN & NDN \\
\hline Tratamentos & \multicolumn{6}{|c|}{ Coelhos } \\
\hline $\mathbf{E}$ & 1 & 2 & 3 & 4 & 5 & 6 \\
\hline FÍGADO & $\begin{array}{c}\text { Esteatose } \\
\text { macrogotícular } \\
(++)\end{array}$ & $\begin{array}{c}\text { Esteatose } \\
\text { macrogotícular } \\
(++)\end{array}$ & $\begin{array}{l}\text { Esteatose }(+++) \\
\text { micro/ } \\
\text { macrogotícular }\end{array}$ & NDN & NDN & NDN \\
\hline ARTÉRIA & Placas $(+++)$ & NDN & Placas $(+++)$ & NDN & NDN & NDN \\
\hline \multicolumn{7}{|l|}{$\mathbf{F}$} \\
\hline FÍGADO & NDN & Esteatose (+) & NDN & NDN & NDN & NDN \\
\hline ARTÉRIA & NDN & NDN & NDN & NDN & NDN & NDN \\
\hline \multicolumn{7}{|l|}{$\mathbf{G}$} \\
\hline FÍGADO & NDN & NDN & $\begin{array}{c}\text { Esteatose } \\
\text { microgoticular (+) }\end{array}$ & NDN & NDN & NDN \\
\hline ARTÉRIA & NDN & NDN & NDN & NDN & NDN & NDN \\
\hline
\end{tabular}


Tabela 8. Determinações histopatológicas em artérias e tecidos em coelhos no período de 150 dias.

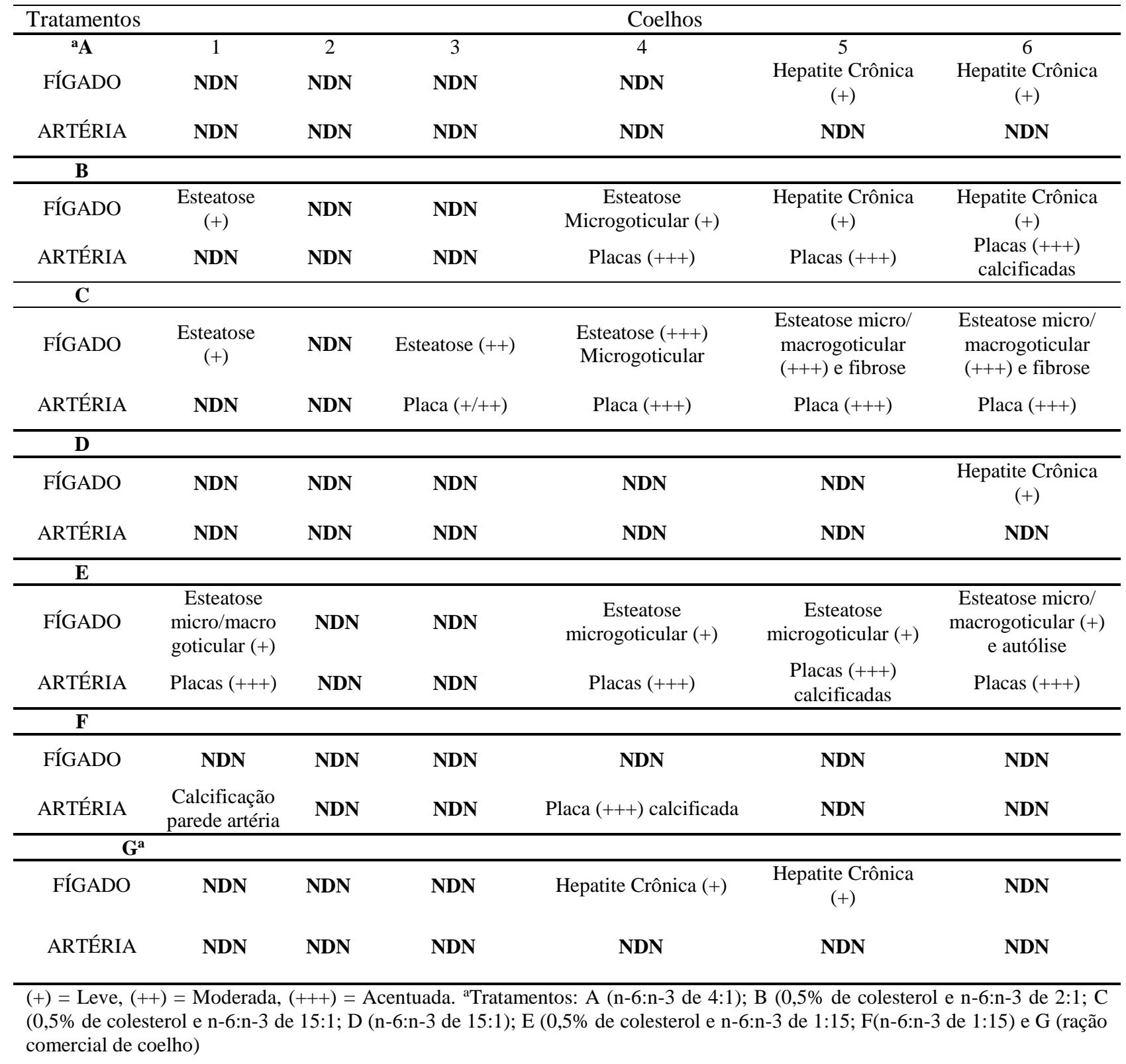

No tratamento D (n-6:n-3 de 15:1), 17\% dos animais apresentaram hepatite crônica periportal leve e artérias nada digno de nota em $100 \%$ deste tratamento. No tratamento E (0,5\% de colesterol e n-6:n-3 de 1:15), 100\% apresentaram esteatose, com características macrogoticular difusa ou centro lobular e médio zonal e/ou centro lobular leve microgoticular e/ou centro lobular e periportal leve micro e macrogoticular e placas ateromatosas grandes por toda a extensão em $100 \%$ dos animais e com $17 \%$ apresentando calcificação. No tratamento F (n6:n-3 de 1:15), 17\% do animais apresentaram esteatose centro lobular leve e em artérias placas 
calcificadas em $17 \%$ e calcificação da parede arterial também em $17 \%$ dos animais. No tratamento $\mathrm{G}$ (ração comercial), foram observados hepatite crônica periportal leve, em 33\% e esteatose microgoticular leve difusa, em $17 \%$ dos animais já em artérias nada digno de nota.

Observamos nos resultados histopatológicos de fígado que os grupos que receberam ração comercial (grupo G) e com relação recomendada 4:1 de n-6:n-3 (Grupo A), ambos apresentaram hepatite crônica leve (33\%), além do grupo D (15:1 de n-6:n-3) que apresentou 17\% dos animais com lesões. Nos tratamentos A e G pode-se sugerir um estudo realizado por Silva et al. (2012) que observou a presença de fragmentos de vírus HCV endógenos causadores de hepatite C no genoma de coelhos, tais vírus com capacidade de infecção e multiplicação, o que pode ter sido desencadeado por fatores ambientais desconhecidos. Esteatose hepática foi observada no restante dos grupos com taxas de $100 \%$ (grupos C e E, que continham respectivamente as proporções de 15:1 e 1:15 de n-6:n-3, com colesterol 1\%), $83 \%$ (Grupo B - 2:1 n-6:n-3, colesterol 1\%) e 17\% nos grupos F e G (1:15 e controle, respectivamente). Inicialmente na patogenia da esteatose, os triacilgliceróis (TAG) acumulam-se nos hepatócitos por causas multifatoriais, uma delas é o aumento do aporte de ácidos graxos livres circulantes (BODEN, 1997), que inibem a captação periférica de glicose estimulada pela insulina e fator de necrose $\alpha$ tumoral (HOTAMISLIGIL et al., 1996). A resistência à insulina leva ao acúmulo de gordura nos hepatócitos por dois mecanismos principais: lipólise e hiperinsulinemia (ÂNGULO, 2002), isso pode explicar a presença de esteatose no grupo $\mathrm{F}$ e nos grupos $\mathrm{C}$ e $\mathrm{E}$, o que se confirma nos dois últimos grupos com a presença de colesterol adicionado à dieta, já que é fato a ocorrência de esteatose quando a dieta é rica em colesterol. Nos grupos $\mathrm{C}$ e E, a esteatose foi classificada como macrogoticular.

Singer, Honigmann e Schliack (1980), demonstraram que o consumo de PUFAs n-3 está associado com o aumento do tamanho das gotículas de gordura em pacientes com esteatose hepática e diabéticos e também ao conteúdo hepático reduzido de EPA, sendo este último inversamente proporcional ao tamanho das gotículas de gordura. Macrogoticular é uma característica da esteato-hepatite não alcoólica caracterizada pelo acúmulo de triacilgliceróis no fígado associado ao desequilíbrio proporção de n-3:n-6 e ao conteúdo reduzido de PUFAs n-3 e elevado de n-6 (SANYAL, 2005; ARAYA et al., 2004). Por outro lado, em muitos casos o efeito primário na esteatose microgoticular é uma anomalia mitocondrial que inclui a betaoxidação mitocondrial de ácidos graxos (HAUTEKEETE; DEGOTT; BENHAMOU, 1990). 
Marsman et al. (2011) induziram esteatose em ratos Wistar durante três semanas suplementando esses animais posteriormente com solução enriquecida com Omega 3 e outra solução com baixíssimo teor deste ácido graxo e alto teor de Omega 6 e um grupo controle que recebeu ração comercial. Após três semanas de tratamento observaram acentuada redução da esteatose nos animais que receberam Omega 3 e lesão significativa nos animais que receberam lipídios com alto teor de Omega 6 e baixo em Omega 3. Isto também foi observado nos coelhos que receberam o tratamento F (1:15 de n-6:n-3) excesso de Omega 3 sem adição de colesterol onde não foi observada a regressão de esteatose no tecido destes animais. Embora o excesso de Omega 6 do tratamento D (15:1 de n-6:n-3) sem colesterol induziu a hepatite crônica.

Os resultados obtidos em artérias mostraram que havia placas de ateroma em todos os animais que receberam dieta hipercolesterolêmica, porém com presença de calcificação apenas no grupo E que continha relação (n-6:n-3 de 1:15 mais 0,5\% de colesterol). Outro fator que chama atenção, é que o grupo $F$ (n-6:n-3 de 1:15, em dieta não colesterolêmica) também apresentou placas calcificadas e calcificação em parede das artérias. Dessa maneira, evidencia-se que tanto o excesso de Omega-3 associado ou não ao consumo de colesterol interfere no crescimento e agravamento das placas ateroscleróticas. No entanto, na literatura, crescimento e agravamento das placas está associado ao excesso de Omega-6 que atua sobre a oxidação da LDL-colesterol (LDLox) que é responsável pela injúria do endotélio. Vários fatores inflamatórios foram relacionados com a oxidação da LDL, promovida pelo excesso de n-6 (GIRAO et al., 2008). Em adição, os leucotrienos da série 4 (LTB4), provenientes do ácido araquidônico da série 6, estão associados a atividades pró-inflamatórias e pró-trombóticas e os da série 3 são precursores de leucotrienos da série 5 que estão associados a atividades anti-inflamatórias e antitrombóticas (McKENNEY; SICA, 2007).

O processo inflamatório é amplificado pela presença de moléculas de adesão, da secreção de interleucinas, proteínas C-reativa e de proteínas morfogênicas de osso pelo endotélio e por células musculares lisas (LIBERMAN et al., 2013). O início da calcificação vascular está relacionado com o desprendimento de condrócitos e osteoblastos normalmente encontrados em cartilagens e ossos que influenciam na nucleação e crescimento de cristais de cálcio (DOHERTY et al., 2004).

Liberman et al. (2011) sugerem que a calcificação arterial é semelhante à formação óssea. A calcificação da placa é a forma mais relevante da aterosclerose e em estudos recentes 
demonstra crescimento dinâmico e estreita ligação com o grau de inflamação vascular. Além disso, LDLox inicia o processo e, posteriormente, durante toda a fase da formação da aterosclerose, induz a expressão e ativa as células osteoblásticas presentes na parede arterial que acabam por promover a deposição de cálcio (LIBERMAN et al., 2013).

A maioria dos estudos com administração de colesterol em dietas de coelhos foi em

períodos bem menores do presente estudo e, mesmo assim, já foi possível observar o desenvolvimento de placa e lesões nas artérias. Bocan et al. (2001), coelhos suplementados com 0,5\% de colesterol durante seis semanas, apresentaram lesões ateroscleróticas com fendas de colesterol e/ou deposição de cálcio. Gavel et al. (2011) utilizou coelhos Nova Zelândia, machos suplementados com colesterol $0,5 \%$ por oito semanas, que também apresentaram considerável desenvolvimento de placas ateroscleróticas.

Kertész et al. (2013), com coelhos alimentados por 12 semanas com e sem colesterol (2\%) e por 40 semanas da mesma maneira, apresentaram crescimento significativo quando feita a comparação tempo e indução de hipercolesterolemia, semelhante aos nossos resultados que apresentaram relação tempo e lesão.

Cayli, Sati e Seval-Celik (2010) alimentou um grupo de coelhos com ração comercial enriquecida com $1 \%$ de colesterol por 12 semanas e outro grupo que recebeu a mesma dieta nas primeiras quatro semanas e nas oito semanas posteriores contendo EPA (ácido eicosapentanóico). O primeiro grupo apresentou placas maiores e infiltradas por células diferenciadas, tais como: macrófagos e células espumosas. Já o segundo grupo, após o tratamento com EPA, continham menor quantidade de células infiltradas e placas de tamanhos bem menores.

Coelhos desenvolvem hipercolesterolemia e lesões arteriais similares aos de humanos, representando um excelente modelo experimental para pesquisar esta doença (McMAHAN, 2008).

\subsection{ANÁLISE DA ATIVIDADE PROTÉICA}

\subsubsection{Análise Imunohistoquímica da Enzima LDL-Receptor em Artérias de Coelhos no Período Total.}


Os resultados da expressão da enzima LDL-receptor no período total do experimento estão representados no Gráfico representado a seguir pela Figura 11.

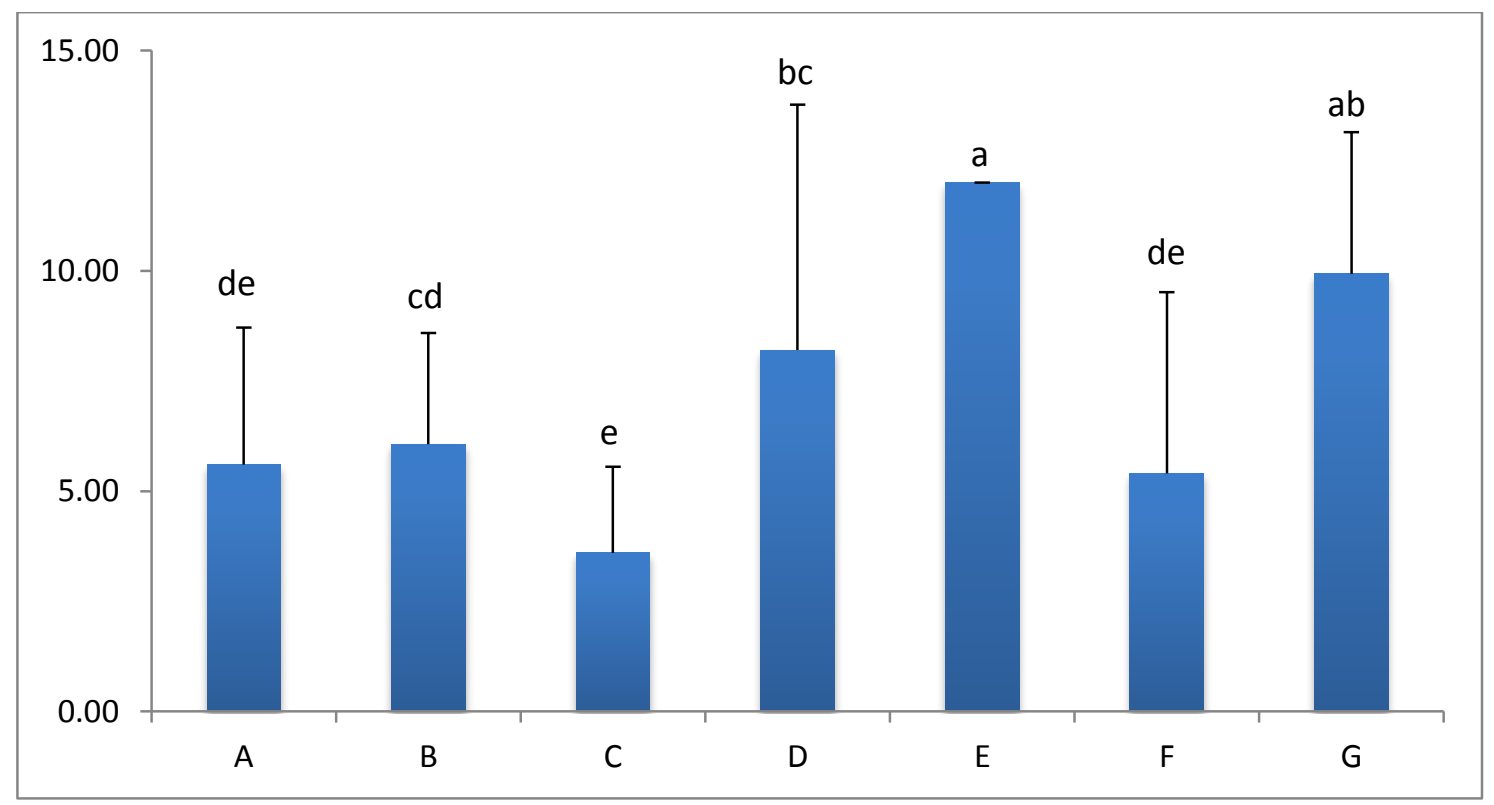

Figura 11. Gráfico da análise da expressão da enzima LDL-receptor em artérias de coelhos do período total de experimento. Tratamentos: A (n-6:n-3 de 4:1); B (0,5\% de colesterol e n-6:n-3 de 2:1; C (0,5\% de colesterol e n-6:n-3 de 15:1; D (n-6:n-3 de 15:1); E (0,5\% de colest colesterol e n-6:n-3 de 1:15; F(n-6:n-3 de 1:15) e G (ração comercial de coelho).

As figuras das análises de imunohistoquímica utilizando o anticorpo LDL - receptor estão representadas com fotos de um animal por tratamento abaixo (Figuras de 12 a 18):

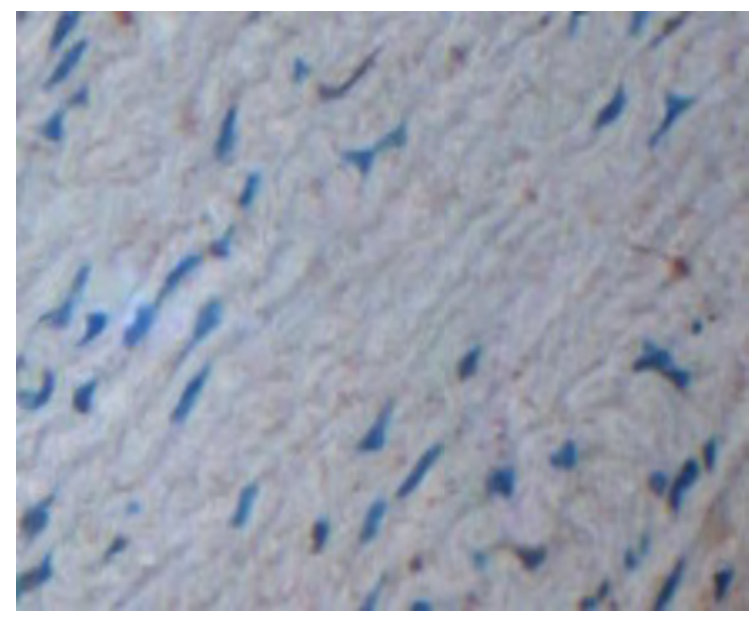

Figura 12. Análise imunohistoquímica em artérias de coelhos do segundo período, anticorpo LDL-r - Tratamento A 


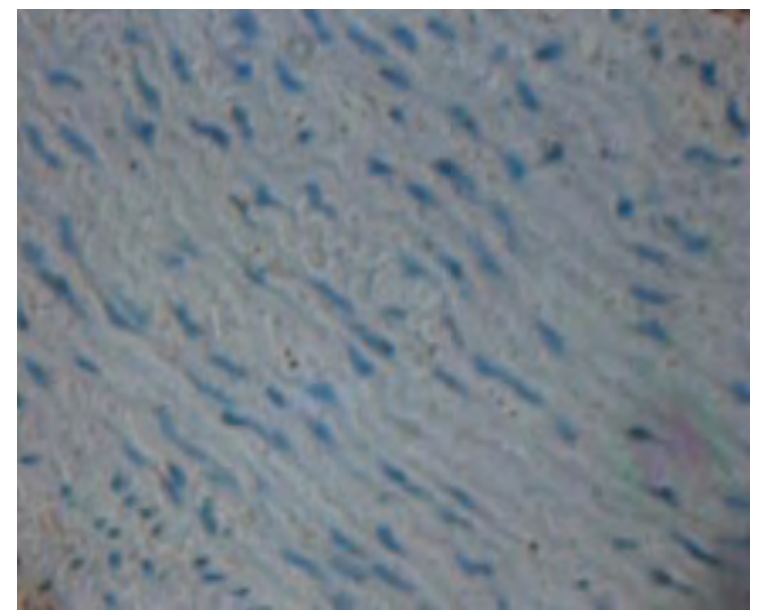

Figura 13. Análise imunohistoquímica em artérias de coelhos do segundo período, anticorpo LDL-r - Tratamento B.

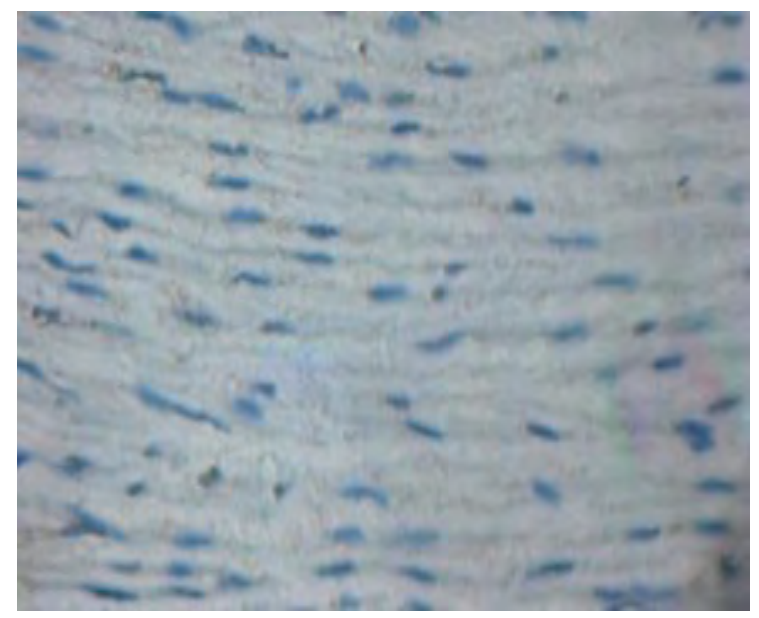

Figura 14. Análise imunohistoquímica em artérias de coelhos do segundo período, anticorpo LDL-r - Tratamento C.

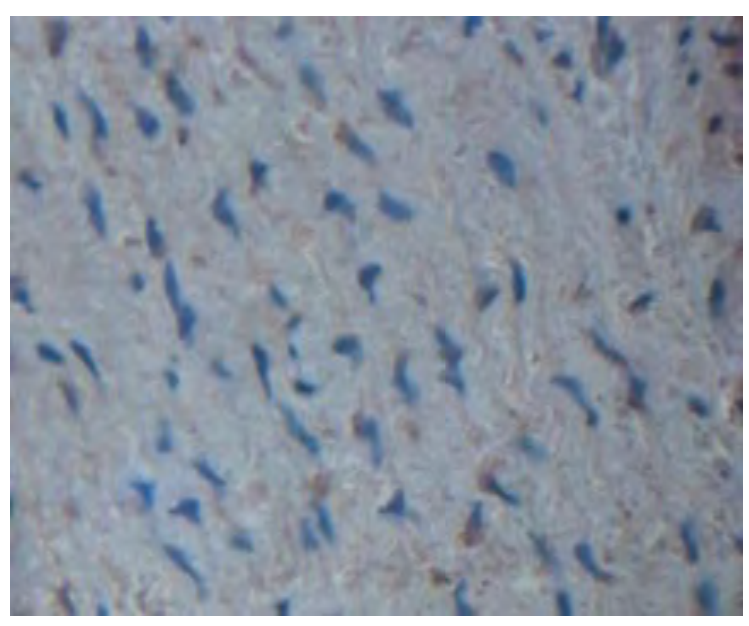

Figura 15. Análise imunohistoquímica em artérias de coelhos do segundo período, anticorpo LDL-r - Tratamento D. 


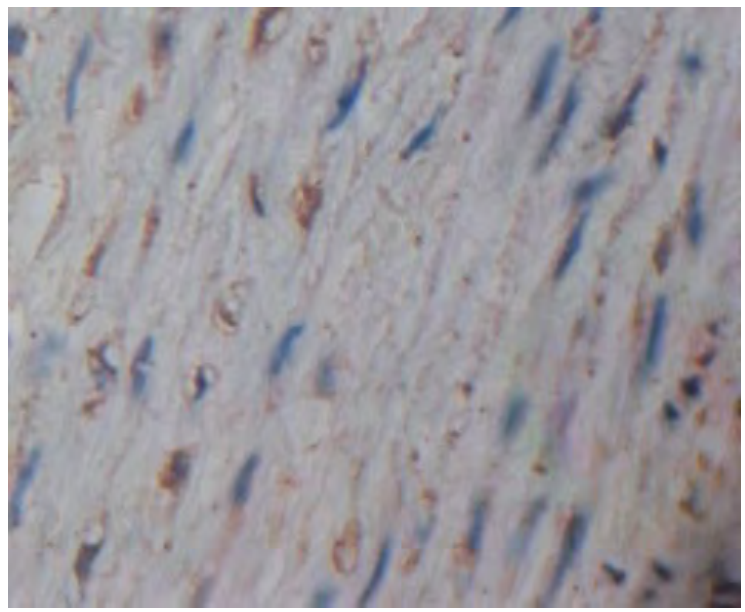

Figura 16. Análise imunohistoquímica em artérias de coelhos do segundo período, anticorpo LDL-r - Tratamento E.

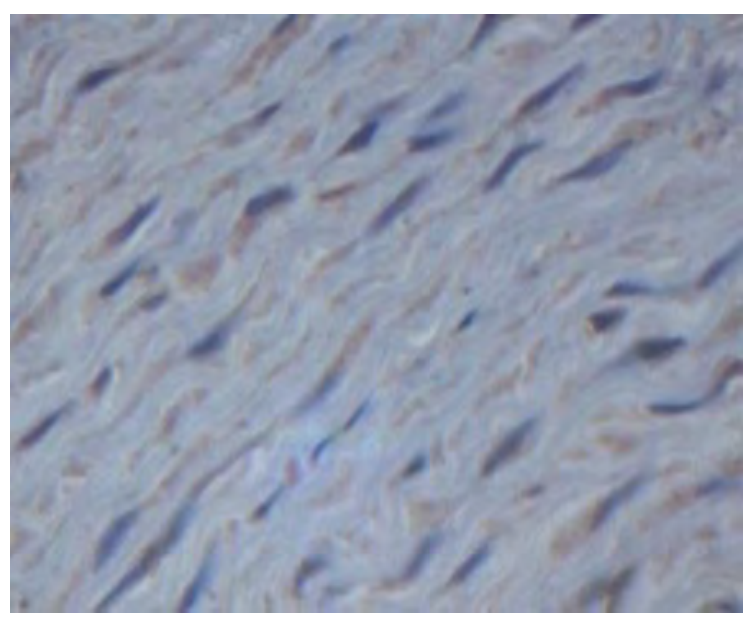

Figura 17. Análise imunohistoquímica em artérias de coelhos do segundo período, anticorpo LDL-r - Tratamento F.

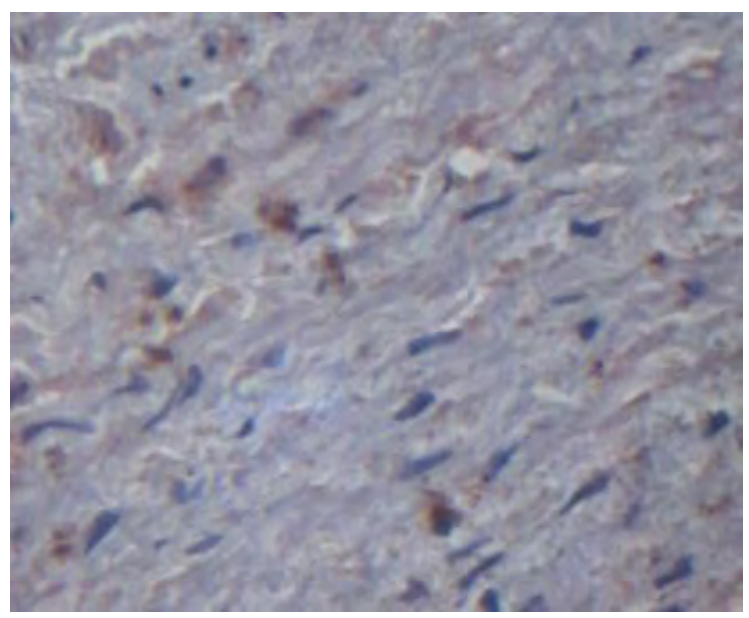

Figura 18. Análise imunohistoquímica em artérias de coelhos do segundo período, anticorpo LDL-r - Tratamento G. 
As maiores expressões da enzima LDL-r em relação aos demais tratamentos foram no tratamento E (n-6:n-3 de 1:15 + 0,5\% de colesterol) e G (ração comercial de coelhos), por sua vez o tratamento $\mathrm{G}$ foi semelhante ao tratamento D (n-6:n-3 de 15:1). O tratamento D, assim como o B (n-6:n-3 de 2:1 + 0,5\% de colesterol) também foram semelhantes na expressão da LDL-r. As menores expressões da enzima LDL-r foram nos tratamentos A (n-6:n-3 de 4:1 grupo controle), B (n-6:n-3 de 2:1 + 0,5\% de colesterol), C (n-6:n-3 de 15:1 + 0,5\% de colesterol) e F (n-6:n-3 de $1: 15)$.

Diante dos resultados podemos observar que tanto o excesso de n-6 quanto de n-3 associados ou não à adição de colesterol foram responsáveis pela maior atividade da LDL-r no endotélio das aortas de coelho que funciona como um mediador, levando a LDL rica em colesterol para dentro das células por um processo de endocitose sendo sua síntese mediada pelo colesterol livre. Por outro lado, quando os coelhos do tratamento B (n-6:n-3 de 2:1 + 0,5\% de colesterol) receberam o tratamento A, que representa o equilíbrio da relação (n-6:n-3), apresentaram a menor expressão da LDL-r, colaborando com os dados da literatura que ressaltam a importância do consumo equilibrado dos ácidos graxos poli-insaturados das séries n-6 e n-3 (SIMOPOULOS, 2008a; 2008b). Isso também é relevante porque a menor expressão da LDLreceptor representa redução de LDL-colesterol circulante, já que esta absorve a LDL-colesterol no sangue. A síntese do receptor LDL é por feedback quando o colesterol é abundante no interior da célula, novos receptores de LDL não são sintetizados e assim a absorção de colesterol do plasma é bloqueado (BERG; TYMOCZKO; STRYER 2002).

No estudo de GROSSO, et al. (2008) com camundongos, a remoção da LDL oxidada reduziria a formação da peroxidação lipídica tanto no plasma quanto no fígado sugerindo um efeito protetor da aterosclerose. As partículas de LDL oxidada aumentam os produtos da peroxidação lipídica, bem como alterações na conformação da apo B (AVOGARO; BITTOLOBON; CAZZOLATO, 1988; 1991). Tais moléculas são citotóxicas em células endoteliais, promovendo o aumento do recrutamento leucocitário, induzindo a liberação de interleucina 8 (IL8, que tem como principal característica a quimiotaxia dos neutrófilos) e MCP-1 (proteína quimiotática dos monócitos 1), prejudicando a angiogênese e diminuindo a afinidade para o receptor de LDL (AVOGARO; BITTOLO-BON; CAZZOLATO, 1988; 1991; HODIS et al., 1994; De CASTELLARNAU et al., 2000; CHEN et al., 2003; BENITEZ et al., 2004). 
Embora, também o excesso de consumo de n-3 poderia proporcionar uma redução na resposta imune do organismo humano (AZEVEDO et al., 2002), já que este atua sobre grupos de eicosanóides específicos que causariam esse efeito pela ação local nas plaquetas, paredes dos vasos sanguíneos, macrófagos e monócitos, aumentando, especialmente, o risco de acidente vascular cerebral hemorrágico (CLARKE et al., 2005). Terano et al. (1983) relataram diminuição da viscosidade do sangue, sendo mais uma causa que contribui para hemorragias, além de diminuir fatores de coagulação da via intrínseca (RYLANCE et al., 1986).

\subsection{DETERMINAÇÃO IN VITRO DA MELHOR RELAÇÃO DE ÁCIDOS GRAXOS N- 6/ÁCIDOS GRAXOS N-3}

\subsubsection{Quantificação de ácidos graxos n-3 e n-6 em Soro de Coelhos e Soro Fetal Bovino de Referência}

As doses de Omega-3 do óleo de peixe testados nas células endoteliais da aorta de coelho variaram de 0,00030 a 0,0000023mg de Omega-3 e de Omega-6, sua variação foi de 0,000032 a $0,00000025 \mathrm{mg}$, para o soro de coelho e de 0,000023 a 0,000000175 mg, para o soro de referência bovino (Tabela 2). As concentrações de Omega-6 já existentes nos soros de coelho e do bovino de referência estão na Tabela 2, em ambos os soros não foi determinada a presença de ácidos graxos Omega-3.

Um estudo realizado por Boone et al. (1971), testou a quantidade de ácidos graxos livres presentes em soro fetal bovino comercial e correlacionou a grande quantidade de ácidos graxos com um menor aporte de crescimento celular. Diascro et al. (1998) comparou a quantidade de ácidos graxos presentes em soro fetal bovino e soro de coelhos e demonstrou uma quantidade quatro vezes maior de ácidos graxos livres no soro de coelho, sendo predominante o ácido linoleico da família n-6, semelhante ao presente estudo.

\subsubsection{Teste dose-resposta induzido por Ácido Graxo Poli-insaturados Omega-3 em Células Endoteliais de Coelhos}




\subsubsection{Quantificação de DNA e RNA}

Após uma semana nas placas com células que apresentavam viabilidade foi realizada a quantificação de DNA e RNA. Os resultados da quantificação estão na Tabela 9.

Foi possível obter quantidades significativas dos ácidos nucleicos RNA e DNA, porém, pode-se observar que a qualidade/pureza de tais eluições ficaram aquém do esperado em algumas amostras, especialmente na extração de DNA.

Tabela 9. Quantificação de DNA e RNA em células endoteliais de coelhos que receberam óleo de peixe.

\begin{tabular}{|c|c|c|c|}
\hline Amostras & Concentração de ácidos nucleicos $(\mathrm{ng} / \mu \mathrm{L})$ & $260 / 280$ & Tipo \\
\hline 1 & 72,7 & 1,58 & RNA \\
\hline 2 & 3,2 & 2,09 & RNA \\
\hline 3 & 152,5 & 1,63 & RNA \\
\hline 4 & 223,4 & 1,68 & RNA \\
\hline 5 & 529,7 & 1,89 & RNA \\
\hline 6 & 275,8 & 1,74 & RNA \\
\hline 7 & 331,4 & 1,75 & RNA \\
\hline 8 & 343,1 & 1,75 & RNA \\
\hline controle & 195,7 & 1,67 & RNA \\
\hline 1 & 39,8 & 1,4 & DNA \\
\hline 2 & 24,8 & 1,32 & DNA \\
\hline 3 & 42,1 & 1,41 & DNA \\
\hline 4 & 70 & 1,38 & DNA \\
\hline 5 & 56 & 1,38 & DNA \\
\hline 6 & 43,1 & 1,39 & DNA \\
\hline 7 & 24,2 & 1,35 & DNA \\
\hline 8 & 42,6 & 1,35 & DNA \\
\hline controle & 44,7 & 1,41 & DNA \\
\hline
\end{tabular}


Com algumas pequenas variações de valores aceitáveis na literatura, para essa relação A260/A280 de indicação de pureza, tivemos como referência valores de 1.7-2.0 provenientes da relação A260/A280 que prediz a pureza do DNA (AHN; COSTA; EMANUEL, 1996) e 1,75-2,01 de RNA, sendo um valor aceitável de indicador para um bom RNA, acima de 1,80 (SAMBROOK; FRITSCH; MANIATIS, 1989).

\subsubsection{Teste de Potencial de Membrana Mitocondrial}

Na Tabela 10, estão os resultados de citometria de fluxo das células endoteliais de aorta de coelhos que receberam óleo de peixe.

Tabela 10. Citometria de fluxo das células endoteliais de aorta de coelhos que receberam óleo de peixe.

\begin{tabular}{cccc} 
& & $\begin{array}{c}\text { Média da } \\
\text { intensidade de } \\
\text { Amostras }\end{array}$ & $\begin{array}{c}\text { Média da intensidade } \\
\text { menos a média da }\end{array}$ \\
& & $\begin{array}{c}\text { corescência do } \\
\text { corante }\end{array}$ & intensidade do negativo \\
Controle & 98,8 & 111 & 14651 \\
negativo & 97,8 & 14762 & 8870 \\
Controle & & 8981 & 10654 \\
positivo & 88,8 & 10765 & 9109 \\
Placa 5 & 94,0 & 9220 & 7679 \\
Placa 6 & 80,0 & 7790 & \\
Placa 7 & 83,8 & & \\
Placa 8 & & & \\
\hline
\end{tabular}

Na Figura 19 está a identificação celular por citometria de fluxo através de parâmetros físicos (tamanho x complexidade) e seleção da população celular. 


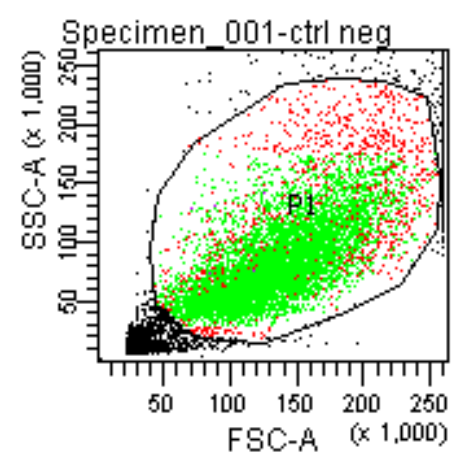

Figura 19. Identificação celular por citometria de fluxo através de parâmetros físicos (tamanho $\mathrm{x}$ complexidade) e seleção da população celular.

Nas Figuras 20 a 25 estão os histogramas das porcentagens de fluorescência e quantidade relativa de células.

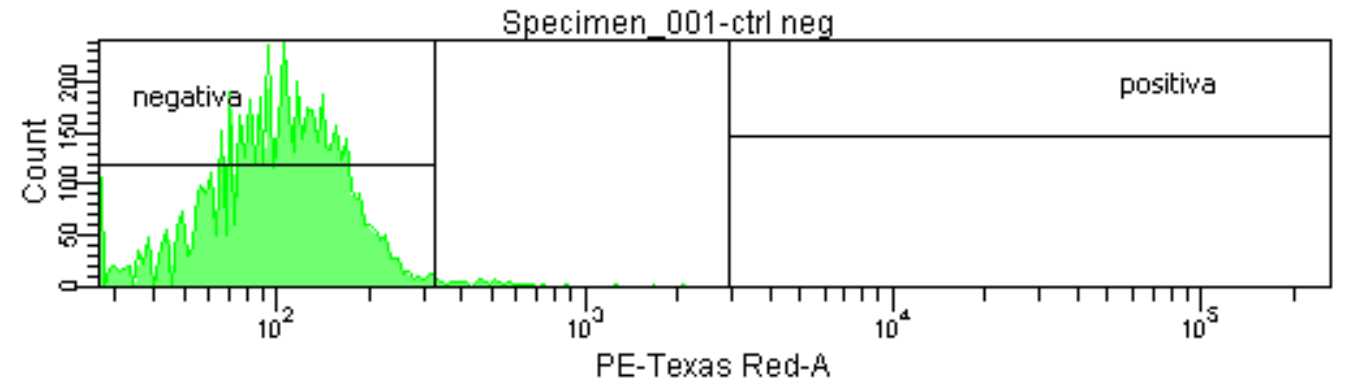

Figura 20. Histogramas das porcentagens de fluorescência e quantidade relativa de células para o controle negativo.

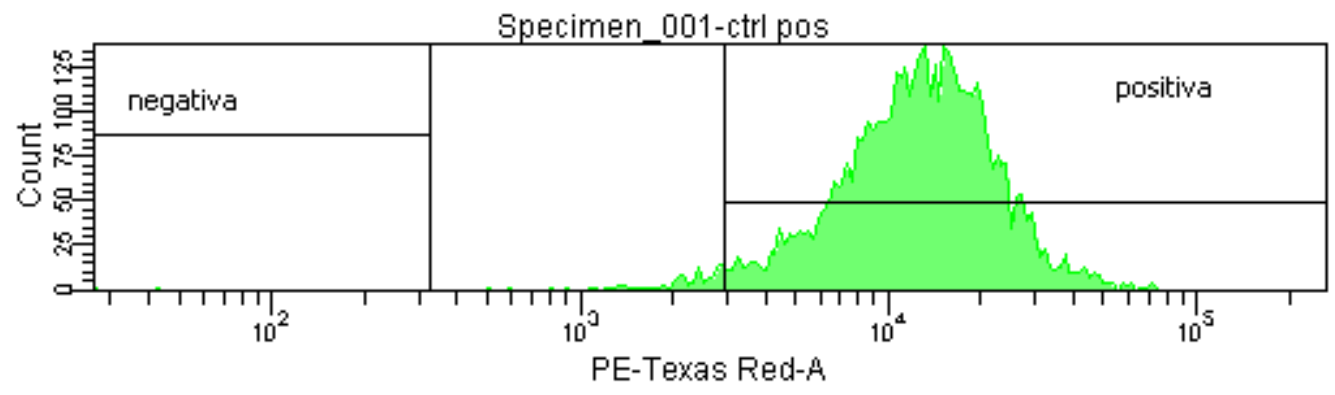

Figura 21. Histogramas das porcentagens de fluorescência e quantidade relativa de células para o controle positivo. 


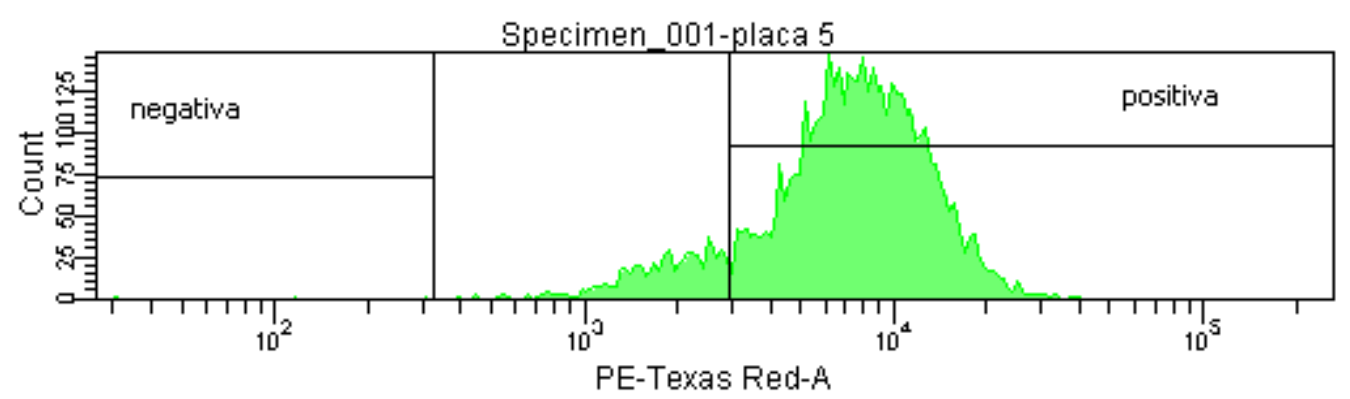

Figura 22. Histogramas das porcentagens de fluorescência e quantidade relativa de células para a placa 5.

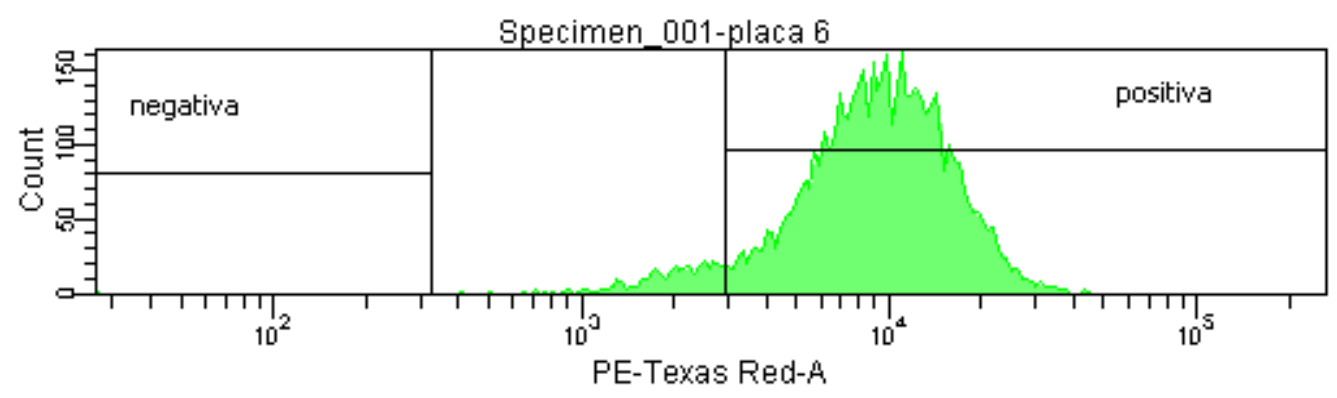

Figura 23. Histogramas das porcentagens de fluorescência e quantidade relativa de células para a placa 6.

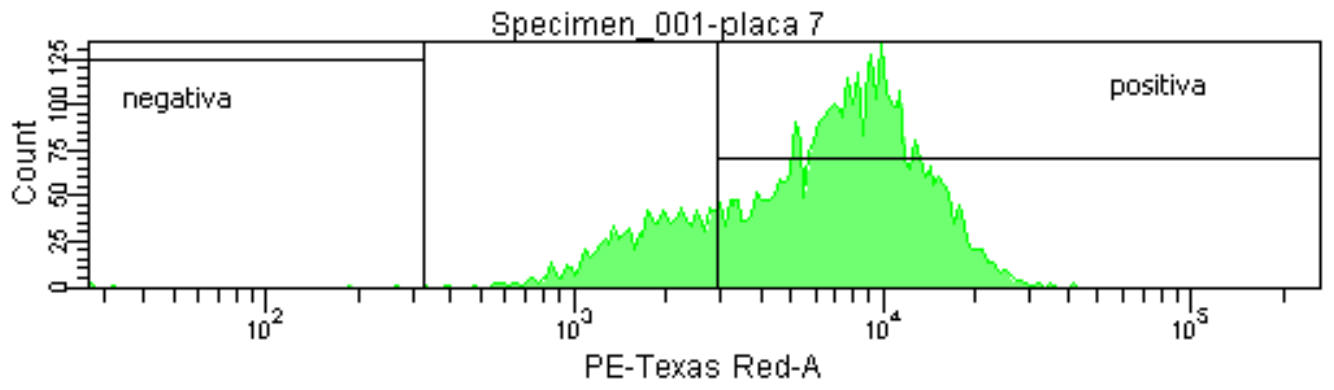

Figura 24. Histogramas das porcentagens de fluorescência e quantidade relativa de células para a placa 7. 


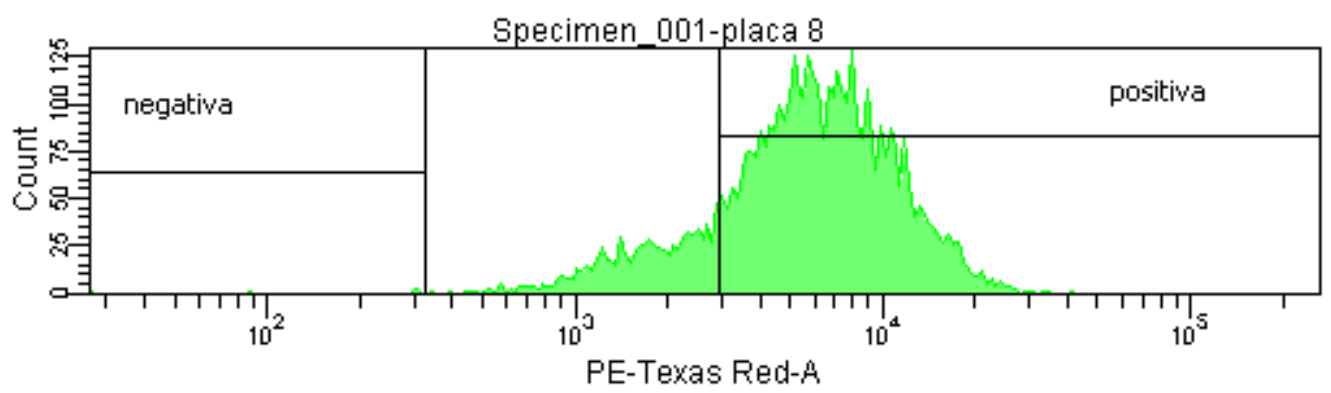

Figura 25. Histogramas das porcentagens de fluorescência e quantidade relativa de células para a placa 8.

Nos resultados obtidos deste estudo, houve viabilidade celular somente nas concentrações de 0,0000187 a 0,0000023 mg/mg de Omega-3, ou seja, a partir das células endoteliais da placa 5 até a placa 8 (Tabela 10). Apesar da viabilidade celular, houve uma diminuição quantitativa das células endoteliais que receberam o óleo de peixe em relação ao controle positivo sem a presença do óleo de peixe. Deste modo, infere-se que o potencial de membrana mitocondrial foi afetado negativamente pelo tratamento e este, estando diretamente ligado aos processos de morte celular programada, possivelmente tais células também teriam sua viabilidade prejudicada a um longo prazo. Tem-se observado que o ácido docosahexaenóico (DHA) causa a morte de células cancerígenas onde a apoptose é induzida pelo mecanismo de citotoxicidade do DHA em células tumorais (GLEISSMAN et al., 2010; LIM et al., 2008). A apoptose ou morte celular programada desempenha um papel crítico tanto no desenvolvimento normal quanto na patologia de vários tecidos (THOMPSON, 1995). Porém, a influência do consumo de óleo de peixe no processo de apoptose ainda não está bem esclarecida (FAGGIN et al., 2000).

De Caterina et al. (1994), refere-se a várias linhas relevantes de evidências fisiológicas que demonstram de 30 a $60 \%$ de inibição pelo DHA sobre a ação de moléculas de adesão celular vascular e outras moléculas indutoras de citocina e isso ocorre independente do estímulo usado, indicando em geral um decréscimo na capacidade de resposta celular aos mediadores peptídicos na atividade endotelial. Tanto a formação do ateroma como a adesão de leucócitos no endotélio e sua subsequente migração transendotelial estão de acordo com o grau de DHA incorporado dentro dos lipídios celulares, demonstrando-se a importância de realizar-se estudos com ácidos graxos poli-insaturados que melhoram a permeabilidade e a fluidez da membrana plasmática, especificamente se estiverem na forma de óleo, por apresentarem afinidade com a estrutura fosfolipídica da membrana celular (MATAIX, 2002). Ao contrário da pesquisa de De Caterina et 


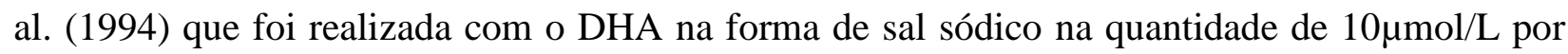
72 horas em culturas de células endoteliais humanas. Fox e Di Corleto (1988) utilizaram uma solução de MaxEPA (extrato de óleo marinho comercial) contendo um total de $30 \%$ de ácidos graxos (sendo 18\% EPA e 12\% DHA) emulsificado com fosfatidilcolina de ovo e incubados com células endoteliais de aorta bovina, observando uma inibição quase total do fator de crescimento derivado de plaquetas (PDGF) na quantidade de $10 \mu \mathrm{g} / \mathrm{mL}$, enquanto que quando utilizou óleo de cártamo que continha 74\% de ácido linoleico Omega 6 também inibiu a produção de PDGF mas com metade da potência do MaxEPA. Sabe-se que o fator de crescimento derivado de plaquetas estimula a migração de células musculares lisas (ROSS, 2005), as quais desenvolvem um papel importante na patogênese de doenças vasculares, sintetizando a maior parte da complexa matriz extracelular arterial, contribuindo para a homeostase e para a formação de lesões ateroscleróticas. Quando ocorre a migração e proliferação dessas células musculares lisas estimuladas pelo PDGF, contribuem para a formação de lesões hiperplásicas intimais, como a aterosclerose (TANG et al., 2012). Além disso as células da musculatura lisa em placas ateroscleróticas podem ser perdidas, via apoptose, desestabilizando a placa e aumentando o risco de trombose (KOCKX; HERMAN, 2000).

É fato que produtos da oxidação do colesterol induzem à apoptose em células, embora Perales et al. (2010), em estudo in vivo e in vitro com cultura de células da musculatura lisa e utilizando aves hipercolesterolêmicas que receberam também 25-hidroxicolesterol (produto da oxidação do colesterol) como modelo experimental, posteriormente, sendo suplementadas com óleo de peixe houve efeito reverso dos danos induzidos pelo colesterol mais o óxido, aumentando a resistência das células da musculatura lisa à apoptose.

Esses achados são muito importantes porque demonstraram que a concentração de DHA viável para as células está entre 0,0000187 a 0,0000023 mg/mg de Omega-3mg, pois doses maiores provocariam toxicidade em células sadias. Em adição, considerando a concentração de Omega 6 onde houve viabilidade celular de 0,000002 a $0,00000025 \mathrm{mg} / \mathrm{mg}$ no soro de coelho e de 0,0000014 a 0,000000175 n-6 no soro bovino, resultaria na proporção de n-6:n-3 de 1:9, ou seja, nove vezes a mais a concentração de Omega 3. O equilíbrio da relação ácidos graxos n6:ácidos graxos n-3 ainda não está claramente estabelecido para indivíduos saudáveis. A maioria dos estudos é com indivíduos que apresentaram hipercolesterolemia e outras enfermidades crônicas. Além disso, a recomendação para um consumo ideal de ácidos graxos n-6: ácidos 
graxos n-3 foi estabelecida de 5:1 (SIMOPOULOS, 2013), respectivamente. Além disso, foi possível isolar as células endoteliais da aorta de coelho e desenvolver um protocolo de cultivo dessas células facilitando estudos futuros sem experimentações com a utilização de um grande número de animais.

\section{CONCLUSÕES}

No geral, o perfil de ácidos graxos no soro correspondeu diretamente com a dieta consumida pelos coelhos.

Os principais efeitos dos ácidos graxos poli-insaturados Omega 3 sobre os lipídeos séricos nos coelhos foram a redução dos teores de colesterol total, LDL-colesterol, VLDL e triacilgliceróis quando os coelhos remanescentes da dieta hipercolesterolêmica $(0,5 \%$ de colesterol e n-6:n-3 de 2:1) passaram a receber o equilíbrio da relação de ácidos graxos 4:1 de n6:n-3, evidenciando a necessidade do consumo equilibrado destes ácidos graxos poli-insaturados.

O teor de colesterol total no soro, nas artérias e o crescimento das placas de ateroma nos coelhos foram influenciados pelo elevado consumo de ácidos graxos n-6 e n-3 associados à adição de colesterol nas dietas. Por outro lado foi verificado que o excesso de Omega 3 associado ou não ao consumo de colesterol contribuiu para o agravamento das placas ateroscleróticas inclusive com deposição de cálcio nas mesmas e paredes endoteliais. Provavelmente, o excesso deste ácido graxo tenha ocasionado efeito contrário às suas funções anti-inflamatória, antiagregatória e anti-trombótica.

Dietas hipercolesterolêmicas provocaram esteatose no tecido hepático de coelhos e o elevado consumo de Omega-6 em detrimento do baixo consumo de Omega -3 induziram hepatite crônica. Já o consumo elevado de Omega-3, mas sem colesterol na dieta regrediu a esteatose no fígado dos animais.

O consumo equilibrado dos ácidos graxos poli-insaturados reduziu a expressão da atividade da enzima LDL-receptor nos animais que estavam anteriormente recebendo dieta hipercolesterolêmica. Ressaltando-se a importância do consumo equilibrado destes ácidos graxos já que esta enzima é controlada pelo colesterol livre circulante.

$\mathrm{Na}$ investigação da melhor relação de ácidos graxos n-6/ ácidos graxos n-3 através do ensaio por dose-resposta em células endoteliais da aorta de coelhos foi evidenciado que a melhor 
proporção de n-6:n-3 seria de 1:9, ou seja, 9 vezes mais do que a concentração de Omega 3 que é recomendada do consumo ideal destes ácidos graxos de 5:1. Em adição, foi possível isolar as células endoteliais da aorta de coelho e desenvolver um protocolo de cultivo dessas células viabilizando estudos futuros sem experimentações com a utilização de um grande número de animais.

\section{REFERÊNCIAS BIBLIOGRÁFICAS}

ADHVARYU, A.; ERHAN, S.Z.; LIU, Z.S.; PEREZ, J.M. Oxidation kinetic studies of oils derived from unmodified and genetically modified vegetables using pressurized differential scanning calorimetry and nuclear magnetic resonance spectroscopy. Thermochimica Acta, v. 364, n. 1, p. 87-97, 2000.

ADHVARYU, A.; ERHAN, S.Z.; PEREZ, J.M. Wax appearance temperatures of vegetable oils determined by differential scanning calorimetry: effect of triacylglycerol structure and its modification. Thermochimica acta, v. 395, n. 1, p. 191-200, 2002.

AHN, S.J.; COSTA, J.; EMANUEL, J.R. PicoGreen Quantitation of DNA: Effective Evaluation of Samples Pre-or Psost-PCR. Nucleic Acids Research, v. 24, n. 13, p. 2623-2625, 1996.

ANGULO, P. Nonalcoholic fatty liver disease. New England Journal of Medicine, v. 346, n. 16, p. 1221-1231, 2002.

AOAC. ASSOCIATION OF OFFICIAL ANALYTICAL CHEMISTS. Official methods of analyses. 13. ed. Washington: AOAC, p. 1051, 1985

AOCS - American Oil Chemist's Society. Official methods and recommended practices of the AOCS. Champaign: AOCS, p. 1200, 1998.

ARAYA, J.; RODRIGO, R.; VIDELA, L.A.; THIELEMANN, L.; ORELLANA, M.;

PETTINELLI, P. PONIACHIK, J., Increase in long-chain polyunsaturated fatty acid n-6:n-3 ratio in relation to hepatic steatosis in patients with non-alcoholic fatty liver disease. Clinical science, v. 106, n. 6, p. 635-643, 2004.

AVOGARO, P.; BON, G.B.; CAZZOLATO, G. Presence of a modified low density lipoprotein in humans. Arteriosclerosis, Thrombosis, and Vascular Biology, v. 8, n. 1, p. 79-87, 1988.

AVOGARO, P.; CAZZOLATO, G.; BITTOLO-BON, G. Some questions concerning a small, more electronegative LDL circulating in human plasma. Atherosclerosis, v. 91, n. 1, p. 163-171, 1991. 
AZEVEDO, R.B.; SILVA, L.P.; LEMOS, A.P.C.; MIYASAKA, C.K.; LACAVA, Z.G.M. Controle da resposta inflamatória por ácidos graxos. In: CURI, R.; POMPÉIA, C.; MIYASAKA, C.K.; PROCOPIO, J. Entendendo a gordura: os ácidos graxos. Barueri: Manole. p. 379-392, 2002

BALKOVÁ, P.; JEŽKOVÁ, J. HLAVÁČKOVÁ, M.; NECKÁŘ, J. STAŇKOVÁ, B.; KOLÁŘ, F.; NOVÁKOVÁ, O. Dietary polyunsaturated fatty acids and adaptation to chronic hypoxia alter acyl composition of serum and heart lipids. British journal of nutrition, v. 102, n. 09, p. 12971307, 2009.

BANG, H. O.; DYERBERG, J.; NIELSEN, AaseBrondum. Plasma lipid and lipoprotein pattern in Greenlandic West-coast Eskimos. The Lancet, v. 297, n. 7710, p. 1143-1146, 1971.

BENÍTEZ, S.; ORDÓÑEZ-LLANOS, J.; FRANCO, M.; MARÍN, C.; PAZ, E.; LÓPEZMIRANDA, J.; SÁNCHEZ-QUESADA, J.L.. Effect of simvastatin in familial hypercholesterolemia on the affinity of electronegative low-density lipoprotein subfractions to the low-density lipoprotein receptor. The American Journal of Cardiology, v. 93, n. 4, p. 414420, 2004.

BERG, J.M.; TYMOCZKO, J.L.; STRYER, L. Biochemistry. 5 ed. W.H. 2002.

BERLINER, J.A.; HEINECKE, J.W. The role of oxidized lipoproteins in atherogenesis. Free Radical Biology and Medicine, v. 20, n. 5, p. 707-727, 1996.

BEST, P.J.M.; HASDAI, D.; SANGIORGI, G.; SCHWARTZ, R.S.; HOLMES, D.R.Jr; SIMARI, R.D. LERMAN, A. Apoptosis, basic concepts and implications in coronary artery disease. Artherioscler. Thromb. Vasc. Biol., v. 19, p. 14-22, 1998.

BLASBALG, T.L.; HIBBELN, J.R; RAMSDEN, C E.; MAJCHRZAK, S.F.; RAWLINGS, R.R.. Changes in consumption of Omega-3 and Omega- 6 fatty acids in the United States during the 20th century. The American journal of clinical nutrition, v. 93, n. 5, p. 950-962, 2011.

BOCAN, T.M.; MUELLER, S.B.; MAZUR, M.J.; UHLENDORF, P.D.; BROWN, E.Q.; KIEFT, K.A., The relationship between the degree of dietary-induced hypercholesterolemia in the rabbit and atherosclerotic lesion formation. Atherosclerosis, v. 102, n. 1, p. 9-22, 1993.

BOCAN, T.M.; KRAUSE, B.R.; ROSEBURY, W.S.; LU, X.; DAGLE, C.; MUELLER, S.B.; SLISKOVIC, D.R. The combined effect of inhibiting both ACAT and HMG-CoA reductase may directly induce atherosclerotic lesion regression. Atherosclerosis, v. 157, n. 1, p. 97-105, 2001.

BODEN, G. Role of fatty acids in the pathogenesis of insulin resistance and NIDDM. Diabetes, v. 46, n. 1, p. 3-10, 1997.

BOONE, C. W.; MANTEL, N.; CARUSO JR, T.D.; KAZAM, E.; STEVENSON, R.E. Quality control studies on fetal bovine serum used in tissue culture. In vitro, v. 7, n. 3, p. 174-189, 1971. 
BÖSINGER, S., LUF, W., BRANDL, E. Oxysterols: their occurrence and biological effects. Int. Dairy J., Amsterdam, v.3, p.1-33, 1993.

BROWN, M.S.; GOLDSTEIN, J.L. A receptor-mediated pathway for cholesterol homeostasis. Science, v. 232, n. 4746, p. 34-47, 1986.

BROWN, A.J.; JESSUP, W.. Oxysterols and atherosclerosis. Atherosclerosis, v. 142, n. 1, p. 128, 1999.

BROWN, J.M; CHUNG, S; SAWYER, J.K. Combined therapy of dietary fish oil and steroyl-CoA desaturase 1 inhibition prevents the metabolic syndrome and atherosclerosis. Arterios. Thromb. Vasc. Biol., v. 30, p. 24-63, 2010.

CALDER, P.C. n-3 Fatty acids and cardiovascular disease: evidence explained and mechanisms explored. CLINICAL SCIENCE., v. 107, n. 1, p. 1-11, 2004.

CALZOLARI, I.; FUMAGALLI, S.; MARCHIONNI, N. Polyunsaturated fatty acids and cardiovascular disease. Current Pharma. Design., v. 15, p. 4094-4102, 2009.

CAMPBELL, J.H.; CAMPBELL; G.R. The role of smooth muscle cells in atherosclerosis. Current opinion in lipidology, v. 5, n. 5, p. 323-330, 1994.

CASTELli, W.P.; ANDERSON, K.; WILSON, P.W, LEVY, D. Lipids and risk of coronary heart disease: the Framingham Study. Ann Epidemiol. v.2: p.23-28, 1992.

De CASTELLARNAU, C.; SANCHEZ-QUESADA, J.L.; BENITEZ, S.; ROSA, R.; CAVEDA, L.; VILA, L.; ORDOÑEZ-LLANOS, J. Electronegative LDL from normolipemic subjects induces IL-8 and monocyte chemotactic protein secretion by human endothelial cells. Arteriosclerosis, thrombosis, and vascular biology, v. 20, n. 10, p. 2281-2287, 2000.

De CATERINA, R.; CYBULSKY, M.I.; CLINTON, S.K.; GIMBRONE, M.A.; LIBBY, P. The Omega-3 fatty acid docosahexaenoate reduces cytokine-induced expression of proatherogenic and proinflammatory proteins in human endothelial cells. Arteriosclerosis, Thrombosis, and Vascular Biology, v. 14, n. 11, p. 1829-1836, 1994.

CAYLI, S; SATI, L; SEVAL-CELIK, Y. The effects of eicosapentaenoic acid on the endothelium of the carotid artery of rabbits on a high-cholesterol diet. Histology and Histopathology., v. 25, p. 141-151, 2010.

CHAMPE, P.C.; HARVEY, R.A. Bioquímica ilustrada. Ed. Artes Médicas, Porto Alegre, RS. 446p. 1997.

CHEN, M.F.; LEE, Y.T.; HSU, H.C.; YEH, P.C.; LIAU, C.S.;HUANG, P.C. Effects of dietary supplementation with fish oil on atherosclerosis and myocardial injury during acute coronary occlusion-reperfusion in diet-induced hypercholesterolemic rabbits. International journal of cardiology, v. 35, n. 3, p. 323-331, 1992. 
CHEN, M.F.; HSU, H.C.; LIAU, C.S.; LEE, Y.T. The role of vitamin E on the antiatherosclerotic effect of fish oil in diet-induced hypercholesterolemic rabbits. Prostaglandins \& other lipid mediators, v. 57, n. 2, p. 99-111, 1999.

CHEN, C.H.; JIANG, T.; YANG, J.H.; JIANG, W.; LU, J.; MARATHE, G.K. Low-density lipoprotein in hypercholesterolemic human plasma induces vascular endothelial cell apoptosis by inhibiting fibroblast growth factor 2 transcription. Circulation, v. 107, n. 16, p. 2102-2108, 2003.

CINTI, D.L.; COOK, L.; NAGI, M.N.; SUNEJA, S.K.; The fatty acid chain elongation system of mammalian endoplasmic reticulum. Progress in lipid research, v. 31, n. 1, p. 1-51, 1992.

CLARKE, J.; HERZBERG, G.; PEELING, J.; BUIST, R.; CORBETT, D. Dietary

supplementation of Omega-3 polyunsaturated fatty acids worsens forelimb motor function after intracerebral hemorrhage in rats. Experimental neurology, v. 191, n. 1, p. 119-127, 2005.

DAMODARAN, S.; PARKIN, K.L..; FENNEMA, O.R. Química de alimentos de Fennema. Artmed, 2010.

DIASCRO, D.D.; VOGEL, R.L.; JOHNSON, T.E.; WITHERUP, K.M.; PITZENBERGER, S.M.; RUTLEDGE, S.J.; PRESCOTT, D.J.; RODAN, G.A.; SCHMIDT, A. High Fatty Acid Content in Rabbit Serum Is Responsible for the Differentiation of Osteoblasts Into

Adipocyte-like Cells. Journal of Bone and Mineral Research, v. 13, n. 1, p. 96-106, 1998. DICZFALUSY, U. Analysis of cholesterol oxidation products in biological samples. Journal of AOAC International, v. 87, n. 2, p. 467-473, 2004.

DOHERTY, T.M.; FITZPATRICK, L.A.; INOUE, D.; QIAO, J.H.; FISHBEIN, M.C.; DETRANO, R.C.; SHAH, P.K.; RAJAVASHISTH, T.B. Molecular, endocrine, and genetic mechanisms of arterial calcification. Endocrine reviews, v. 25, n. 4, p. 629-672, 2004.

EATON, S.B.; EATON, B.S.; KONNER, J.M.; SHOSTAK, M. An evolutionary perspective enhances understanding of human nutritional requirements. Progress in Lipid Research, v. 47, p. 172-187, 1998a.

EATON, S.B.; EATON, B.S.; SINCLAIR, A.J.; CORDAIN, L.;MANN, N.J. Dietary intake of Long chain polyunsaturated fatty acids during the Paleolithic. World Rev. Nutr. Diet, v. 83, p. 12-23, $1998 b$.

ECHEVERRI, D.; MÓNTES, F.; DELGADILLO, A.; CABRALES, J. Effects of the simultaneous use of drug-eluting stents and statins in an atherosclerotic animal model. Clínica e Investigación en Arteriosclerosis, v. 25, n. 1, p. 16-24, 2013.

ERKKILA A.; DE MELLO, V.D.F.; RISÉRUS, ULF.; LAAKSONEN, D.E. Dietary fatty acids And cardiovascular disease: Na epidemiological approach. J. Nutr., v. 121, p. 1732-1740, 2008.

FAGGIN, E.; PUATO, M.; CHIAVEGATO, A.; FRANCH, R.; PAULETTO, P.; SARTORE, S. Fish oil supplementation prevents neointima formation in nonhypercholesterolemic balloon- 
injured rabbit carotid artery by reducing medial and adventitial cell activation. Arteriosclerosis, thrombosis, and vascular biology, v. 20, n. 1, p. 152-163, 2000.

FOX, P.L.; DICORLETO, P.E. Fish oils inhibit endothelial cell production of platelet-derived growth factor-like protein. Science, v. 241, n. 4864, p. 453-456, 1988.

GANONG, W.F. Review of medical physiology. In: Energy, balance, metabolism \& nutrition. Cap. 17 , p. 255-289, 1995

GAVEL, N.T.; EDEL, A.L.; BASSETT, C.M.; WEBER, A.M.; MERCHANT, M.; RODRIGUEZ-LEYVA, D.; PIERCE, G.N. The effect of dietary hempseed on atherogenesis and contractile function in aortae from hypercholesterolemic rabbits. Acta Physiologica Hungarica, v. 98, n. 3, p. 273-283, 2011.

GIRAO, H.; MOTA, M.C.; PAMALHO, J.; PEREIRA, P. Cholesterol oxides accumulation in human catararacts. Exp. Eye Res., v. 66, p. 645-652, 2008.

GLEISSMAN, H.; YANG, R.; MARTINOD, K.; LINDSKOG, M.; SERHAN, C.N.; JONHNSEN, J.I. Docosahexaenoic acid metabolome in neural tumors: identification of cytotoxic intermediates. The FASEB Journal, v. 24, n. 3, p. 906-915, 2010.

GORDON, M.H. The development of oxidative rancidity in foods. In: POKORNÝ, J.; YANISHLIEVA, N.; GORDON, M. Antioxidants in food: practical applications. Elsevier, p.229, 2001.

GROSSO, D.M.; FERDERBAR, S.; WANSCHEL, A.C.B.A.; KRIEGER, M.H.; HIGUSHI, M.L.; ABDALLA, D.S.P. Antibodies against electronegative LDL inhibit atherosclerosis in LDLr-/-mice. Brazilian Journal of Medical and Biological Research, v. 41, n. 12, p. 10861092, 2008.

GUARDIOLA, F.; CODONY, R.; MISKIN, D.; RAFECAS, M.; BOATELLA, J. Oxysterol Formation in Egg Powder and Relationship with Other Quality Parameters. Journal of Agricultural and Food Chemistry, v. 45, n. 10, p. 4190-4190, 1997.

GUILLOU, H.; ZADRAVEC, D.; MARTIN, P. G.; JACOBSSON, A. The key roles of elongases and desaturases in mammalian fatty acid metabolism: Insights from transgenic mice. Progress in lipid research, v. 49, n. 2, p. 186-199, 2010.

HARDMAN, W. E. Omega-3 fatty acids to augment cancer therapy. The Journal of nutrition, v. 132, n. 11, p. 3508S-3512S, 2002.

HARRIS, W.S.; CONNOR, W.E.; MCMURRY, M.P. The comparative reductions of the plasma lipids and lipoproteins by dietary polyunsaturated fats: salmon oil versus vegetable oils.

Metabolism, v. 32, n. 2, p. 179-184, 1983. 
HARRIS, W. S.; BULCHANDANI, D. Why do Omega-3 fatty acids lower serum triglycerides?. Current opinion in lipidology, v. 17, n. 4, p. 387-393, 2006.

HARRIS, W.S.; MOZAFFARIAN, D.; RIMM, E.; KRIS-ETHERTON, P.; RUDEL, L.L.; APPEL, L.J.; ENGLER, M.M.; ENGLER, M.B.; SACKS, F. Omega-6 fatty acids and risk for cardiovascular disease a science advisory from the American Heart Association Nutrition Subcommittee of the Council on Nutrition, Physical Activity, and Metabolism; Council on Cardiovascular Nursing; and Council on Epidemiology and Prevention. Circulation, v. 119, n. 6, p. 902-907, 2009.

HAVEL, R.J. T. Triglyceride-rich lipoproteins and plasma lipid transport. Arterios. Thromb. Vasc. Biol., v. 30, p. 9-19, 2010.

HAWTHORNE, A. B.; FILIPOWICZ, B. L.; EDWARDS, T. J.; HAWKEY, C. J. High dose eicosapentaenoic acid ethyl ester: effects on lipids and neutrophil leukotriene production in normal volunteers. British journal of clinical pharmacology, v. 30, n. 2, p. 187-194, 1990.

HAUTEKEETE, M. L.; DEGOTT, C.; BENHAMOU, J. P. Microvesicular steatosis of the liver. Acta Clinica Belgica, v. 45, n. 5, p. 311-326, 1989.

HEDELIN, M.; CHANG, E.T.; WIKLUND, F.; BELLOCCO, R.; KLINT, A.; ADOLFSSON, J.; SHAHEDI, K.; XU, J.; ADAMI, H O.; CRONBERG, H.; BALTER, K.A. Association of frequent consumption of fatty fish with prostate cancer risk is modified by COX-2 polymorphism. Int. J. Cancer, v. 120, p. 398-405, 2007.

HIRAI, A.; HAMAZAKI, T.; TERANO, T.; NISHIKAWA, T.; TAMURA, Y.; KUMAGAI, A.; SAJIKI, J. Eicosapentaenoic Acid and Platelet Function in Japanese. The Lancet, v. 316, n. 8204, p. 1132-1133, 1980.

HODIS, H.N.; KRAMSCH, D.M.; AVOGARO, P.; BITTOLO-BON, G.; CAZZOLATO, G.; HWANG, J.; PETERSON, H.; SEVANIAN, A. Biochemical and cytotoxic characteristics of an in vivo circulating oxidized low density lipoprotein (LDL-). Journal of lipid research, v. 35, n. 4, p. 669-677, 1994.

HOTAMISLIGIL, G.S.; PERALDI, P.; BUDAVARI, A.; ELLIS, R.; WHITE, M.F.; SPIEGELMAN, B.M. IRS-1-mediated inhibition of insulin receptor tyrosine kinase activity in TNF- $\alpha$-and obesity-induced insulin resistance. Science, v. 271, n. 5249, p. 665-670, 1996.

HUGHES-FULFORD, M.; TJANDRAWINATA, R.R.; LI, C.F.; SAYYAH, S. Arachidonic acid, an Omega6 fatty acid, induces cytoplasmic phospholipase A2 in prostate carcinoma cells. Carcinogenesis, v. 26, p. 1520-1526, 2005.

IHARA-WATANABE, M., UMEKAWA, H., TAKAHASHI, T., \& FURUICHI, Y. Comparative effects of safflower oil and perilla oil on serum and hepatic lipid levels, fatty acid compositions of serum and hepatic phospholipids, and hepatic mRNA expressions of 3-hydroxy-3- 
methylglutaryl CoA reductase, LDL receptor, and cholesterol 7alpha-hydroxylase in young and adult rats. Food research international, v. 33, n. 10, p. 893-900, 2000.

IMAI, H.; WERTHESSEN, N.T.; SUBRAMANYAM, V.; LEQUESNE, P.W.; SOLOWAY, A.H.; KANISAWA, M. Angiotoxicity of oxigenated sterols and possible precursors. Science, London, v.207, p.651-653, 1980.

INNERARITY, T.L.; BORÉN, J.; YAMANAKA, S.; OLOFSSON, S.O. Biosynthesis of Apolipoprotein B48-containing Lipoproteins REGULATION BY NOVEL POST-

TRANSCRIPTIONAL MECHANISMS. Journal of Biological Chemistry, v. 271, n. 5, p. 23532356, 1996.

ISHII, H., HIRAISHI, S., KUBOKI, M., SUGIURA, T., WAKU, K., \& KAZAMA, M. The effect of plasma on platelet function in hypercholesterolemic rabbits and the changes in fatty acid composition of the plasma. Thrombosis research, v. 34, n. 5, p. 447-455, 1984.

JAKOBSSON, A.; WESTERBERG, R.; JACOBSSON, A. Fatty acid elongases in mammals: their regulation and roles in metabolism. Progress in lipid research, v. 45, n. 3, p. 237-249, 2006.

JAMES, M.J.; GIBSON, R.A.; CLELAND, L.G. Dietary polyunsaturated fatty acids and inflammatory mediator production. The American journal of clinical nutrition, v. 71, n. 1, p. 343s-348s, 2000.

JEON, H.; BLACKLOW, S.C. Structure and physiologic function of the low-density lipoprotein receptor. Annu. Rev. Biochem., v. 74, p. 535-562, 2005.

JOHNSON, L.V.; WALSH, M.L.; CHEN, L.B. Localization of mitochondria in living cells with rhodamine 123. Proceedings of the National Academy of Sciences, v. 77, n. 2, p. 990-994, 1980.

KERTÉSZ, A.; BOMBICZ, M.; PRIKSZ, D.; BALLA, J.; BALLA, G.; GESZTELYI, R.; VARGA, B.; HAINES, D.D.; TOSAKI, A.; JUHASZ, B. Adverse impact of diet-induced hypercholesterolemia on cardiovascular tissue homeostasis in a rabbit model: time-dependent changes in cardiac parameters. International journal of molecular sciences, v. 14, n. 9, p. 19086-19108, 2013.

KOCKX, M.M.; HERMAN, A.G. Apoptosis in atherosclerosis: beneficial or detrimental?. Cardiovascular research, v. 45, n. 3, p. 736-746, 2000.

KOLODGIE, F.D.; GOLD, H.K.; BURKE, A.P.; FOWLER, D.R.; KRUTH, H.S.; WEBER, D.K.; FARB, A.; GUERRERO, L.J.; HAYASE, M.; KUTYS, R.; NARULA, J.; FINN, A.V.; VIRMANI, R. Intraplaque hemorrhage and progression of coronary atheroma. New England Journal of Medicine, v. 349, n. 24, p. 2316-2325, 2003. 
LEONARDUZZI, G.; SOTTERO, B.; POLI, G. Oxidized products of cholesterol: dietary and metabolic origin, and proatherosclerotic effects (review). The Journal of nutritional biochemistry, v. 13, n. 12, p. 700-710, 2002.

LIBERMAN, M.; JOHNSON, R.C.; HANDY, D.E.; LOSCALZO, J.; LEOPOLD, J. A.Bone morphogenetic protein-2 activates NADPH oxidase to increase endoplasmic reticulum stress and human coronary artery smooth muscle cell calcification. Biochemical and biophysical research communications, v. 413, n. 3, p. 436-441, 2011.

LIBERMAN, M.; PESARO, A.E.P.; CARMO, L.S.; SERRANO Jr, C.V. Vascular calcification: pathophysiology and clinical implications. Einstein (Sao Paulo), v. 11, n. 3, p. 376-382, 2013.

LICHTENSTEIN, A.H.; AUSMAN, L.M.; CARRASCO, W.; JENNER, J.L.; ORDOVAS, J.M.; SCHAEFER, E.J. Hypercholesterolemic effect of dietary cholesterol in diets enriched in polyunsaturated and saturated fat. Dietary cholesterol, fat saturation, and plasma lipids.

Arteriosclerosis, Thrombosis, and Vascular Biology, v. 14, n. 1, p. 168-175, 1994.

LIZARD, G.; MONIER, S.; CORDELET, C.; GESQUIÉRE, L.; DECKET, V.; LAGROST, L.; GAMBERT, P. Characterization and comparison of the mode of death, apoptosis versus necrosis, induced by $7 \beta$-hydroxycholesterol and 7-ketocholesterol in the cells of the vascular wall. Arteriosclerosis, thrombosis, and vascular biology, v. 19, p. 1190-1200, 1999.

LIM, K.; HAN, C.; XU, L.; ISSE, K.; DEMETRIS, A.J.; WU, T. Cyclooxygenase-2-derived prostaglandin $\mathrm{E} 2$ activates $\beta$-catenin in human cholangiocarcinoma cells: evidence for inhibition of these signaling pathways by $\omega 3$ polyunsaturated fatty acids. Cancer Research, v. 68 , n. 2, p. 553-560, 2008.

LORDAN, S.; MACKRILL, J.J.; O'BRIEN, N.M. Oxysterols and mechanisms of apoptotic signaling: implications in the pathology of degenerative diseases. The Journal of nutritional biochemistry, v. 20, n. 5, p. 321-336, 2009.

LOUHERANTA AM, PORKKALA-SARATAHO EK, NYYSSONEN MK, SALONEN RM, SALONEN JT. Linoleic acid intake and susceptibility of very-low-density and low density lipoproteins to oxidation in men. The American journal of clinical nutrition, v. 63, n. 5, p. 698-703, 1996.

Da LUZ , P.L.; UINT, L. Endotélio na aterosclerose: interações celulares e vasomotricidade. In: Da Luz PL, Laurindo FRM, Chagas ACP. Endotélio e doenças cardiovasculares. São Paulo: Ed. Atheneu; p. 131-60, 2003.

MARSMAN, H.A.; HEGER, M.; KLOEK, J.J.; NIENHUIS, S.L.; van WERVEN, J.R.; NEDERVEEN, A.J.; ten KATE, F.J.W.; STOKER, J.; van GULIK, T. M. Reversal of hepatic steatosis by Omega-3 fatty acids measured non-invasively by $1 \mathrm{H}$-magnetic resonance spectroscopy in a rat model. Journal of gastroenterology and hepatology, v. 26, n. 2, p. 356$363,2011$. 
MATAIX, J.; GIL, A. Libro blanco de los Omega-3. Granada, España: Puleva Food, 2002.

MAYNERIS-PERXACHS, J.; BONDIA-PONS, I.; SERRA-MAJEM, L.; CASTELLOTE, A.I.; LÓPEZ-SABATER, M.C. Long-chain $\omega 3$ fatty acids and classical cardiovascular disease risk factors among the Catalan population. Food Chem., v.119, p. 54-61, 2010.

MAZALLI, M.R.; SALDANHA, T.; BRAGAGNOLO, N. Determinação de colesterol em ovos: comparação entre um método enzimático e um método por cromatografia líquida de alta eficiência. Revista do Instituto Adolfo Lutz, v.62, n.1, p.49-54, 2003.

McKENNEY, J.M.; SICA, D. Prescription Omega-3 fatty acids for the treatment of hypertriglyceridemia. American Journal of Health-System Pharmacy, v. 64, n. 6, p. 595-605, 2007.

McMAHAN, C.A.; GIDDING, S.S.; McGILL, H.C. Coronary heart disease risk factors and atherosclerosis in young people. J. Clin. Lipidology., v. 2, p. 118-126, 2008.

MESCHY, F. Tables of composition and nutritional value of feed materials. INRA ed., Wageningen Academic Publishers, p. 295, 2007.

MEYER, B.J.; MANN, N.J.; LEWIS, J.L.; MILLIGAN, G.C.; SINCLAIR, A.J.; HOWE, P.R. Dietary intakes and food sources of omega- 6 and omega-3 polyunsaturated fatty acids. Lipids, v. 38, n. 4, p. 391-398, 2003.

MOREL, D.W.; LIN, C.Y. Cellular biochemistry of oxysterols derived from the diet or oxidation in vivo. The Journal of Nutritional Biochemistry, v. 7, n. 9, p. 495-506, 1996.

NETTLETON, J.A. Introduction to fatty acids. In: Omega $\mathbf{- 3}$ fatty acids and health, Inst. Fd. Tech, 1995.

NIELSEN, J.H.; OLSEN, C.E.; DUEDAHL, C.; SKIBSTED, L.H. Isolation and quantification of cholesterol oxides in dairy products by selected ion monitoring mass spectrometry. Journal of dairy research, v. 62, n. 01, p. 101-113, 1995.

OLKKONEN, V.M.; BÉASLAS, O.; NISSILÄ, E.. Oxysterols and their cellular effectors. Biomolecules, v. 2, n. 1, p. 76-103, 2012.

OTAEGUI-ARRAZOLA, A.; MENENDEZ-CARREÑO, M.; ANSORENA, D.; ASTIASARAN, I. Oxysterols: a world to explore. Food and Chemical Toxicology, v. 48, n. 12, p. 3289-3303, 2010.

PANIANGVAIT, P.; KING, A.J; JONES, A.D.; GERMAN, B.G. Cholesterol oxides in foods of animal origin. J. Food. Sci., v. 60, p. 1159-1174, 1995. 
PARKINSON, A.J.; CRUZ, A.L.; HEYWARD W.L.; BULKOW, L.R.; HALL, D.;

BARSTADED, L.; CONNOR, W.E. Elevated concentrations of plasma n-3 polyunsaturated fatty acids among Alaskan Eskimos. Am. J. Clin. Nutr., USA, v. 59, p. 384-388, 1994.

PARWARESCH, M. R.; HAACKE, H.; MÄDER, C. Efficacy of hypolipidemic treatment in inhibition of experimental atherosclerosis: the effect of nicotinic acid and related compounds. Atherosclerosis, v. 31, n. 4, p. 395-401, 1978.

PENG, S.; HU, B.; MORIN, R.J. Angiotoxicity and atherogenicity of cholesterol oxides. J. Clin. Lab. Anal., New York, v.5, p.144-152, 1991.

PERALES, S.; ALEJANDRE, M. J.; MORALES, R. P., TORRES; C.,; LINARES, A. Fish oil supplementation reverses the effect of cholesterol on apoptotic gene expression in smooth muscle cells. Lipids in health and disease, v. 9, n. 1, p. 70, 2010.

PRATT, D.A.; MILLS, J.H.; PORTER, N.A. Theoretical calculations of carbon-oxygen bond dissociation enthalpies of peroxyl radicals formed in the autoxidation of lipids. Journal of the American Chemical Society, v. 125, n. 19, p. 5801-5810, 2003.

REAVEN, G.M. The insulin resistance syndrome: definition and dietary approaches to treatment. Annu. Rev. Nutr., v. 25, p. 391-406, 2005.

REMMELE, W.; STEGNER, H.E. Recommendation for uniform definition of an immunoreactive score (IRS) for immunohistochemical estrogen receptor detection (ER-ICA) in breast cancer tissue. Der Pathologe, v. 8, n. 3, p. 138-40, 1987.

RIBEIRO JORGE, P.A.; NEYRA, L.C.; OZAKI, R.M.; de ALMEIDA, E. Efeito dos ácidos graxos Omega-3 sobre o relaxamento-dependente do endotélio em coelhos hipercolesterolêmicos. Arq. Bras. Cardiol., v.69, p.13-18, 1997.

ROBERTS, L.J.; MONTINE, T.J.; MARKESBERY, W.R.; TAPPER, A.R.; HARDY, P.; CHEMTOB, S.; DETTBARN, W.D.; MORROW, J. D. Formation of isoprostane-like compounds (neuroprostanes) in vivo from docosahexaenoic acid. Journal of Biological Chemistry, v. 273, n. 22, p. 13605-13612, 1998.

RONG, J.X,; RANGASWAMY, S.; SHEN, L.; DAVE, R.; CHANG, Y.H.; PETERSON, H.; HODIS, H.N.; CHISOLM, G.M.; SEVIAN, A. Arterial injury by cholesterol oxidation products causes endothelial dysfunction and arterial wall cholesterol accumulation. Artherioscler. Thromb. Vasc.Biol., v. 18, p. 1885-1894, 1998.

RONG, J.X,; SHEN, L.; DAVE, R.; CHANG, Y.H.; RICHTERS, A.; HODIS, H.N.; SEVIAN, A. Cholesterol oxidation products induce vascular foam cell lesion formation in hypercholesterolemic New Zealand white rabbits. Artherioscler. Thromb. Vasc. Biol., v. 19, p. 2179-2188, 1999.

ROSS R. The pathogenesis of atherosclerosis. An update. N Engl J Med 1986; 314: 488500. treatment. Annu Rev Nutr. v. 25, p.391-406, 2005. 
RYLANCE, P.B.; GORDGE, M.P.; SAYNOR, R.; PARSONS, V.; WESTON, M.J. Fish oil modifies lipids and reduces platelet aggregability in haemodialysis patients. Nephron, v. 43, n. 3, p. 196-202, 1986.

SANYAL, A.J. Mechanisms of Disease: pathogenesis of nonalcoholic fatty liver disease. Nature Clinical Practice Gastroenterology \& Hepatology, v. 2, n. 1, p. 46-53, 2005.

SAMBROOK J, FRITSCH EF, MANIATIS T. Molecular cloning. New York: Cold spring harbor laboratory press, 1989.

SCANU, A.M. AND SPECTOR, A.A. Biochemistry and biology of plasma lipoproteins, In: The Biochemistry of Disease, ed. Marcel Dekker, vol. 11, p. 495 505, New York, 1986.

SCHILSTRA, M.J.; VELDINK, G.A.; VERHAGEN, J.; VLIEGENTHART, J.F. Effect of lipid hydroperoxide on lipoxygenase kinetics. Biochemistry, v. 31, n. 33, p. 7692-7699, 1992.

SHAHIDI, Fereidoon. Bailey's Industrial Oil and Fat Products., Edible Oils and Fat products: Chemistry, Properties, and Health effects. Volume 1, 2005.

SHANNON J.; KING I.B.; MOSHOFSKKY R.; LAMPE J.W.; LI GAO D.; RAY R.M.; THOMAS D.B. Erytrocyte fatty acids and breast cancer risk: a case control study in Shangai, China. Am. J. Clin. Nutr., v. 85, p. 1090-1097, 2007.

SHIMAMURA, T.; WILSON, A.C. Influence of dietary fish oil on the aortic, myocardial, and renal lesions of SHR. Journal of nutritional science and vitaminology, v. 37, n. 6, p. 581-590, 1991.

SIGMA-ALDRICH; Figura moléculas de LDL e LDL-Receptor. Disponível em: http://www.sigmaaldrich.com/life-science/metabolomics/enzyme-explorer/learningcenter/plasma-blood-protein/lipoproteinfunction.html Acesso em: novembro de 2014.

SILVA, F. de AS e; AZEVEDO, CAV de. A new version of the assistat-statistical assistance software. In: World Congress on computers in agriculture. Orlando: American Society of Agricultural Engineers, p. 393-396, 2006.

SILVA, E.; MARQUES, S.; OSÓRIO, H.; CARVALHEIRA, J.; THOMPSON, G. Endogenous Hepatitis C Virus Homolog Fragments in European Rabbit and Hare Genomes Replicate in Cell Culture. PloS one, v. 7, n. 11, p. e49820, 2012.

SIMOPOULOS, A. P. Evolutionary aspects of diet, the Omega-6/Omega-3 ratio and genetic variation: nutritional implications for chronic diseases. Biomedicine \& Pharmacotherapy, v. 60, n. 9, p. 502-507, 2006.

SIMOPOULOS, A. P. The importance of the omga-6/Omega-3 fatty acid ratio in cardiovascular disease and other chronic diseases. Exp. Biol. Med., v. 233, p. 674-688, 2008 a.

SIMOPOULOS, A. P. The omga-6/Omega-3 fatty acid ratio, genetic variation, and cardiovascular disease. Asia Pac. J. Clin. Nutr., v. 17, p. 131-134, 2008 b. 
SIMOPOULOS, A.P. Dietary Omega-3 fatty acid deficiency and high fructose intake in the development of metabolic syndrome, brain metabolic abnormalities, and non-alcoholic fatty liver disease. Nutrients, v. 5, n. 8, p. 2901-2923, 2013.

SMITH, L.L.; TENG, J.I.; LIN, Y.Y.; SEITZ. P.K.; McGEHEE, M.F. Sterol metabolism. XLVII. Oxidized cholesterol esters in human tissues. J. Steroid Biochem., v. 14, p. 889-900, 1981.

SMITH, L.L. Cholesterol autoxidation, Chem Physis. Lipids, v.44, p.87-125, 1987.

SMITH, L.L. Mechanisms of formation of oxysterols: a general survey. Free Radical Lipoproteins and Membrane Lipids. Plenum Press, New York, p.409, 1990. SMITH, L.L. Review of progress in sterol oxidations: 1987-1995. Lipids., v. 31, p. 453-487, 1996.

SMITH, M.B.; MARCH, J. March's advanced organic chemistry: reactions, mechanisms, and structure. John Wiley \& Sons, 2007.

SINGER, P.; HONIGMANN, G.; SCHLIACK, V. Decrease of eicosapentaenoic acid in fatty liver of diabetic subjects. Prostaglandins and medicine, v. 5, n. 3, p. 183-200, 1980.

STATISTICA StatSoft. Copyright® 1994-2013 Tulsa, Oklahoma. versão 12, 2014.

TALLMAN, K.A.; ROSCHEK, B.; PORTER, N.A. Factors influencing the autoxidation of fatty acids: effect of olefin geometry of the nonconjugated diene. Journal of the American Chemical Society, v. 126, n. 30, p. 9240-9247, 2004.

TANG, Z.; WANG, A.; YUAN, F.; YAN, Z.; LIU, B.; CHU, J.S.; HELMS, J.A.; LI, S. Differentiation of multipotent vascular stem cells contributes to vascular diseases. Nature communications, v. 3, p. 875, 2012.

TEITELBAUM, J.E.; WALKER, W.A. Review: The role of Omega 3 fatty acids in intestinal inflamation J. Nutr. Biochem., New York, v.12, p.21-32, 2001.

TERANO, T.; HIRAI, A.; HAMAZAKI, T.; KOBAYASHI, S.; FUJITA, T.; TAMURA, Y.; KUMAGAI, A. Effect of oral administration of highly purified eicosapentaenoic acid on platelet function, blood viscosity and red cell deformability in healthy human subjects. Atherosclerosis, v. 46, n. 3, p. 321-331, 1983.

THOMPSON, Craig B. Apoptosis in the pathogenesis and treatment of disease. Science, v. 267, n. 5203, p. 1456-1462, 1995.

TULETA, I.; BAURIEDEL, G.; HASENBANK, I. Antiplatelet effects of n-3 polyunsaturated fatty acids compared with aspirin: A pilot study with whole-blood aggregometry. Tromb.

Research., v. 124, p. 724-726, 2009. 
VAJRESWARI, A.; RUPALATHA M.; RAO, P.S. Effect of altered dietary $\omega 6$-to- $\omega 3$ fatty acid ratio on erythrocyte lipid composition and membrane-bound enzymes. J. Nutr. Sci. Vitaminol., v. 48, p. 365-370, 2002.

VOSS, A.C. Atualidades dietéticas. Abbot produtos nutricionais, v. I n. 1, jul. 2004.

WALZEM, R.L. Liproteins and the laying hen: form follows function. Poult. Avian Biol. Rev., v7, (no 1) p. 31-34, 1996.

WASOWICZ, E. Cholesterol and phytosterols. In: Sikorski, Z.E.; Kolakowska, A. Chemical and functional properties of food lipids. Washington, DC, CRC Press, p.344, 2003.

YANNI, A.E. The laboratory rabbit: an animal model of atherosclerosis research. Laboratory animals, v. 38, n. 3, p. 246-256, 2004.

YAO, P.; TABAS, I. Free cholesterol loading of macrophages induceds apoptosis involving the fas pathway. J. Biol. Chem., v. 275, p. 23807-23813, 2000.

ZHU, Bo-Qing et al. Inhibition of atherosclerosis by fish oil in cholesterol-fed rabbits. Journal of the American College of Cardiology, v. 12, n. 4, p. 1073-1078, 1988. 


\section{UNIVERSIDADE DE SÃO PAULO}

Faculdade de Zootecnia e Engenharia de Alimentos

Departamento de Ciências Básicas

Pirassununga, 30 de outubro de 2009.

Assunto: Emissão de parecer do Comitê de Ética em Experimentação Animal da FZEA.

Prezada Professora,

Tendo por base os princípios estabelecidos no Regimento Geral do Comitê de Ética em Experimentação Animal da FZEA/USP, informo que o projeto de pesquisa "Importância da relação dos ácidos graxos ômega-6/ômega3 na alimentação", coordenado pela Profa. Dra. Mônica Roberta Mazalli recebeu parecer favorável de um pesquisador que atua na área de experimentação animal. Deste modo, a Comissão de Ética em Experimentação Animal da FZEA considerou-o aprovado.

Atenciosamente,

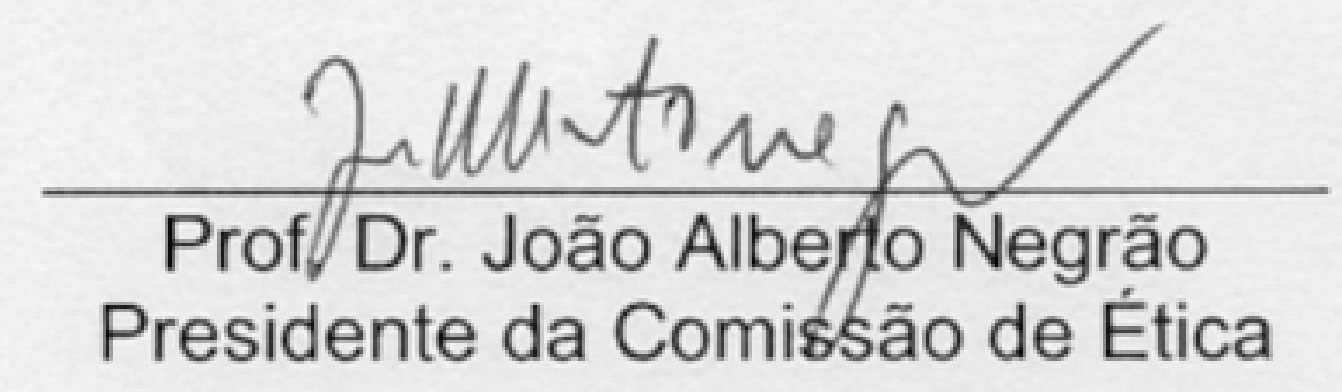

Profa. Dra. Mônica Roberta Mazalli

Departamento de Engenharia de Alimentos 